\title{
Interventions before consultations for helping patients address their information needs (Review)
}

\author{
Kinnersley P, Edwards AGK, Hood K, Cadbury N, Ryan R, Prout H, Owen D, MacBeth F,
} Butow P, Butler C

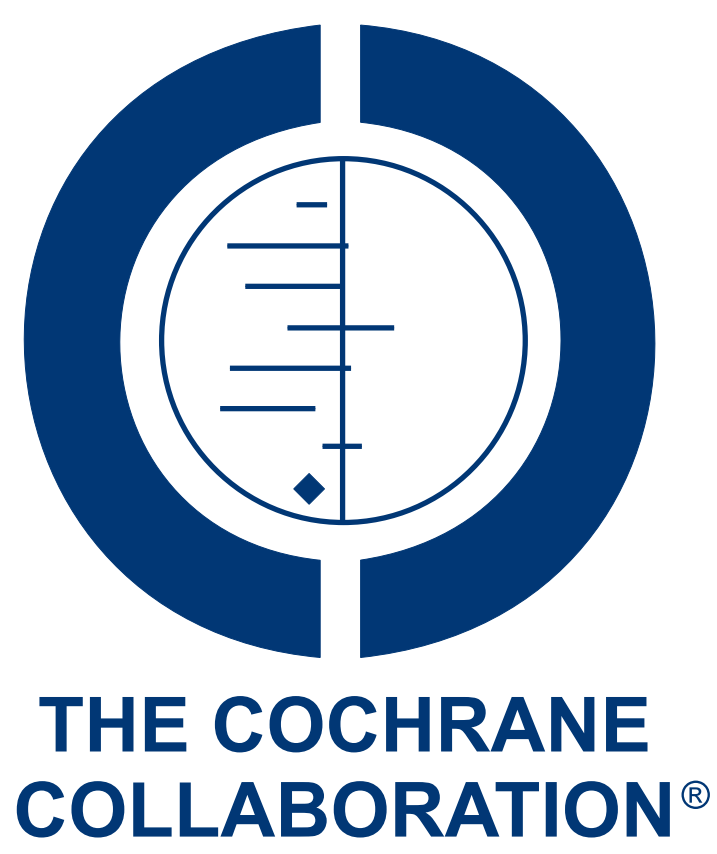

This is a reprint of a Cochrane review, prepared and maintained by The Cochrane Collaboration and published in The Cochrane Library 2009, Issue 1

http://www.thecochranelibrary.com

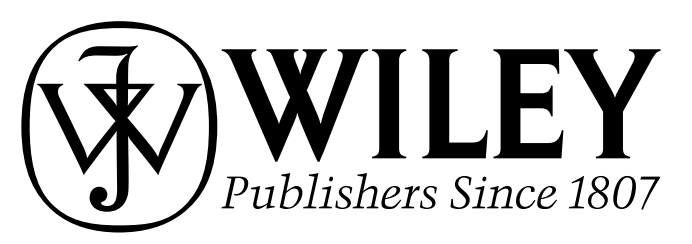

Interventions before consultations for helping patients address their information needs (Review)

Copyright (@) 2009 The Cochrane Collaboration. Published by John Wiley \& Sons, Ltd. 
TABLE OF CONTENTS

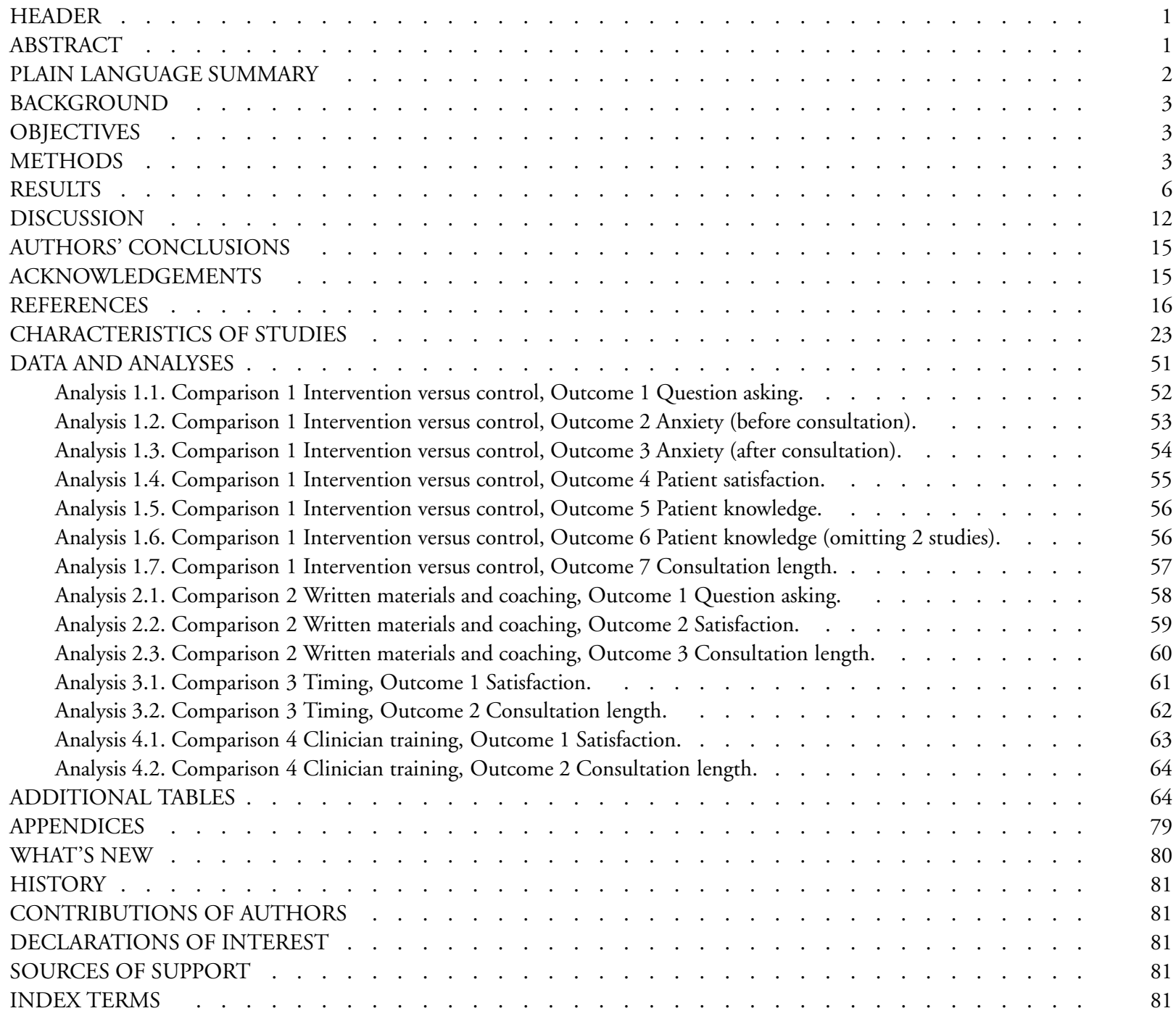




\title{
Interventions before consultations for helping patients address their information needs
}

Paul Kinnersley ${ }^{1}$, Adrian GK Edwards ${ }^{1}$, Kerry Hood ${ }^{1}$, Naomi Cadbury ${ }^{1}$, Rebecca Ryan ${ }^{2}$, Hayley Prout ${ }^{1}$, Diane Owen ${ }^{3}$, Fergus MacBeth $^{4}$, Phyllis Butow ${ }^{5}$, Christopher Butler ${ }^{1}$

${ }^{1}$ Department of Primary Care and Public Health, School of Medicine, Cardiff University, Cardiff, UK. ${ }^{2}$ Cochrane Consumers and Communication Review Group, Australian Institute for Primary Care, La Trobe University, Bundoora, Australia. ${ }^{3}$ Primary Care Group, School of Medicine, Swansea University, Swansea, UK. ${ }^{4}$ Centre for Clinical Practice, National Institute for Health and Clinical Excellence, London, UK. ${ }^{5}$ School of Psychology, University of Sydney, Sydney, Australia

Contact address: Paul Kinnersley, Department of Primary Care and Public Health, School of Medicine, Cardiff University, 3rd Floor, Neuadd Meirionnydd, Heath Park, Cardiff, Wales, CF14 4XN, UK. kinnersley@cf.ac.uk.

Editorial group: Cochrane Consumers and Communication Group.

Publication status and date: Edited (no change to conclusions), published in Issue 1, 2009.

Review content assessed as up-to-date: 28 September 2006.

Citation: Kinnersley P, Edwards AGK, Hood K, Cadbury N, Ryan R, Prout H, Owen D, MacBeth F, Butow P, Butler C. Interventions before consultations for helping patients address their information needs. Cochrane Database of Systematic Reviews 2007, Issue 3. Art. No.: CD004565. DOI: 10.1002/14651858.CD004565.pub2.

Copyright (C) 2009 The Cochrane Collaboration. Published by John Wiley \& Sons, Ltd.

\begin{abstract}
A B S T R A C T
Background

Patients often do not get the information they require from doctors and nurses. To address this problem, interventions directed at patients to help them gather information in their healthcare consultations have been proposed and tested.
\end{abstract}

\section{Objectives}

To assess the effects on patients, clinicians and the healthcare system of interventions which are delivered before consultations, and which have been designed to help patients (and/or their representatives) address their information needs within consultations.

Search methods

We searched: the Cochrane Central Register of Controlled Trials (CENTRAL, The Cochrane Library (issue 3 2006); MEDLINE (1966 to September 2006); EMBASE (1980 to September 2006); PsycINFO (1985 to September 2006); and other databases, with no language restriction. We also searched reference lists of articles and related reviews, and handsearched Patient Education and Counseling (1986 to September 2006).

\section{Selection criteria}

Randomised controlled trials of interventions before consultations designed to encourage question asking and information gathering by the patient.

Data collection and analysis

Two researchers assessed the search output independently to identify potentially-relevant studies, selected studies for inclusion, and extracted data. We conducted a narrative synthesis of the included trials, and meta-analyses of five outcomes. 


\section{Main results}

We identified 33 randomised controlled trials, from 6 countries and in a range of settings. A total of 8244 patients was randomised and entered into studies. The most common interventions were question checklists and patient coaching. Most interventions were delivered immediately before the consultations.

Commonly-occurring outcomes were: question asking, patient participation, patient anxiety, knowledge, satisfaction and consultation length. A minority of studies showed positive effects for these outcomes. Meta-analyses, however, showed small and statistically significant increases for question asking (standardised mean difference (SMD) 0.27 (95\% confidence interval (CI) 0.19 to 0.36 )) and patient satisfaction (SMD 0.09 (95\% CI 0.03 to 0.16$)$ ). There was a notable but not statistically significant decrease in patient anxiety before consultations (weighted mean difference (WMD) -1.56 (95\% CI -7.10 to 3.97)). There were small and not statistically significant changes in patient anxiety after consultations (reduced) (SMD -0.08 (95\%CI -0.22 to 0.06$)$ ), patient knowledge (reduced) (SMD 0.34 (95\% CI -0.94 to 0.25$)$ ), and consultation length (increased) (SMD 0.10 (95\% CI -0.05 to 0.25$)$ ). Further analyses showed that both coaching and written materials produced similar effects on question asking but that coaching produced a smaller increase in consultation length and a larger increase in patient satisfaction.

Interventions immediately before consultations led to a small and statistically significant increase in consultation length, whereas those implemented some time before the consultation had no effect. Both interventions immediately before the consultation and those some time before it led to small increases in patient satisfaction, but this was only statistically significant for those immediately before the consultation. There appear to be no clear benefits from clinician training in addition to patient interventions, although the evidence is limited.

\section{Authors' conclusions}

Interventions before consultations designed to help patients address their information needs within consultations produce limited benefits to patients. Further research could explore whether the quality of questions is increased, whether anxiety before consultations is reduced, the effects on other outcomes and the impact of training and the timing of interventions. More studies need to consider the timing of interventions and possibly the type of training provided to clinicians.

\section{PLAIN LANGUAGE S UMMARY}

\section{Interventions before healthcare consultations for helping patients get the information they require}

Patients often report that they want more information from their healthcare providers or that the information they do receive does not address their needs. Generally, the amount of information given is small. People have differing needs for information, which also varies with the specific illness, but providing information is important as it helps patients recall, understand and follow treatment advice and be more satisfied. Clinicians may underestimate or undervalue the information needs of patients. They may also lack the skills to give information effectively. Training doctors and nurses probably helps, but another approach is to try to directly help patients ask questions in their consultations. This can be done by various methods such as question prompt sheets (which encourage patients to write down their questions) or coaching (when someone helps the patient to think of the questions they want to ask). This review evaluated studies of these types of interventions.

We identified 33 randomised controlled trials involving 8244 patients from six countries, mainly the USA, in a range of clinical settings. Most interventions, which included written materials (for example, question prompt sheets) and coaching sessions, were delivered in the waiting room immediately before the consultation. They were compared to dummy interventions or usual care. Health issues included primary care and family medicine, cancer, diabetes, heart problems, women's issues, peptic ulcer and mental illness.

We found small increases in question asking and patient satisfaction and a possible reduction in patient anxiety before and after consultations. We also found a possible reduction in patient knowledge and a possible small increase in consultation length. Both coaching and written materials produced similar effects on asking questions but coaching had a larger benefit in terms of patient satisfaction. Interventions immediately before the consultation led to a small increase in patient satisfaction whereas giving the intervention some time before did not. Interventions immediately before the consultation also resulted in small increases in consultation length, particularly when using written materials rather than coaching. Interventions some time before the consultation did not alter consultation time.

Copyright (C) 2009 The Cochrane Collaboration. Published by John Wiley \& Sons, Ltd. 
The interventions seem to help patients ask more questions in consultations, but do not have other clear benefits. Doctors and nurses need to continue to try to help their patients ask questions in consultations and question prompt sheets or coaching may help in some circumstances.

\section{B A C K G R O U N D}

Patients (or healthcare consumers) often report that they want more information from clinicians (doctors and nurses) or that the information they do receive does not address their particular needs (Boberg 2003; Boreham 1978; Jenkins 2001). External observation confirms that the amount of information usually given to patients is small (Ford 1995; Maguire 1996; Svarstad 1974; Waitzkin 1984). Patients have varying information needs and clinicians need to tailor the information given accordingly (Leydon 2000; Meredith 1996). Providing information is important because it is a determinant of patient satisfaction, compliance, recall and understanding (Deyo 1986; Faden 1981; Hall 1988). It has also been associated with symptom resolution, reduced emotional distress, physiological status, use of analgesia, length of hospital stay and quality of life (Egbert 1964; Fallowfield 1994; Kaplan 1989; Roter 1995; Stewart 1995). Failure to give information, or the provision of unwanted information, can reduce the benefits of the consultation or can cause negative outcomes (Fallowfield 1999).

Information giving may be poor for a number of reasons. Clinicians may underestimate or undervalue the information needs of patients (Beisecker 1990; Faden 1981; Kindelan 1987; Tuckett 1985; Waitzkin 1984). Alternatively, they may overestimate the amount of information they give (Makoul 1995), lack the skills to give information (Jenkins 2002; Maguire 1986; Tuckett 1985) or use technical language and jargon (Korsch 1968). Furthermore, patients may feel intimidated or otherwise unable to voice their needs (Leydon 2000; McKenzie 2000; Stimson 1975; Tuckett 1985). This may be particularly relevant for patients with serious or life-threatening diseases to whom clinicians may be reluctant to give information, believing it to be harmful (Fleissig 2000; Jefford 2002; Silverman 2005).

Improving clinicians' provision of information to patients presents challenges. Clinicians' skills may not improve even with specific training, which can be resource intensive and in which clinicians may be reluctant to participate (Fallowfield 2002; Kramer 2004). As an adjunct or alternative, interventions directed at helping patients express their information needs and address them in consultations have been evaluated. Various methods has been identified to encourage patients to ask questions, including coaching sessions before consultations (Greenfield 1988), videos (Lewis 1991), and written materials (for example, question prompt sheets) (Butow
1994). Various outcomes have been studied with some positive results. For example, Greenfield and colleagues (Greenfield 1988) found that a 20-minute patient coaching session delivered before consultations to improve participation and information-seeking skills in the consultation led to patients reporting improved physical outcomes. Other positive results including increased patient satisfaction and improved psychological adjustment have been found in studies in both primary care and hospital settings, among patients with various conditions (Butow 1994; Kaplan 1989; Rost 1991; Roter 1977).

Despite these apparent benefits, we know of no routine implementation of strategies to help patients address their information needs. Given the large number of patients who consult clinicians in hospital and primary care settings, this suggests that there is either lack of knowledge of the potential benefits, doubts about the consistency of the evidence, or concerns about unforeseen negative outcomes. In these circumstances a systematic review is required to evaluate the current evidence, identify further research needs, and inform decisions about implementation of the interventions.

This review complements a number of other Cochrane reviews; for example, the review by Wetzels et al (Wetzels 2007) which focuses on interventions to involve older patients in primary care, the review by Scott et al (Scott 2003) on the provision of tape recordings or summaries of consultations, and the review by Lewin et al (Lewin 2001) of interventions aimed at providers to promote patient-centred care.

\section{O B JE C T IVES}

To assess the effects on patients, clinicians and the healthcare system of interventions which are delivered before consultations, and which have been designed to help patients (and/or their representatives) address their information needs within consultations.

\section{METHODS}

\section{Criteria for considering studies for this review}




\section{Types of studies}

Randomised controlled trials (RCTs).

Excluded: controlled (non-randomised) clinical trials (CCTs), prospective cohort studies (including controlled before-and-after studies and interrupted time series), studies without comparison groups, individual case reports.

In the protocol for this review we planned to include RCTs, CCTs and prospective cohort studies including controlled before-and-after studies and interrupted time series. This inclusive approach was designed to avoid missing important data in a rapidly expanding field, preliminary exploration of which suggested that few RCTs existed. However, we found 33 RCTs meeting the inclusion criteria for this review. Therefore we were able to raise the threshold for study design inclusion to include RCTs only, as these provide a more robust level of evidence than other study designs.

\section{Types of participants}

Patients and/or their representatives (or carers) of all ages before 'one-to-one' consultations with doctors or nurses in healthcare settings.

Excluded: Individuals or groups attending activities such as health promotion clinics (for example, antenatal classes) or in-patients for whom there were not specific subsequent identifiable consultations. Individuals consulting other healthcare professionals.

\section{Types of interventions}

Interventions directed at individual patients, representatives or carers before a consultation and intended to help them address their information needs in the consultation.

Evidence of this intention was that patients were encouraged to:

- consider and/or express their information needs by identifying and asking questions;

- consider and/or express the amount and content of information they require;

- consider how they might express their information needs in the consultation;

- consider how they might overcome barriers to communication within the consultation; and/or

- clarify and/or check their understanding of information provided in the consultation.

We excluded:

- interventions provided to patients during their consultations, for example information leaflets about illnesses or diseases, and decision aids;

- symptom diaries, unless the material appeared to encourage identification of patient information needs as well as provision of information;

- interventions describing treatment options and effects of treatments;
- interventions intended to provide patients with more information about their symptoms or illness unless this was intended to help the patient identify further information needs;

- interventions intended to improve communication other than addressing information needs;

- training and other interventions solely targeted at clinicians to encourage them to change their consulting behaviour, for example by providing more information to patients;

- interventions intended to help patients address information needs outside consultations.

\section{Types of outcome measures}

We categorised outcomes into three major domains:

1. the consultation process;

2. the consultation outcome; and

3. service outcomes.

This allowed us to distinguish between measures of change in the consultation process (for example, patient question asking) and measures of consultation outcome (for example, psychological health after the consultation).

Within the second domain of consultation outcomes, we used two sub-domains, as we considered primary outcomes to be measures of patient health (2a) and secondary outcomes to be measures which reflected the care the patient had received, or their experience or perception of it (such as patient satisfaction) (2b).

We considered service outcomes (domain 3), that is the effects of interventions on clinicians and the service as a whole, since benefits to patients must be weighed against other effects.

We thus intended to identify a range of outcomes which would provide data about the consultation process and outcomes for patients and service providers, and which enabled us to summarise data across studies.

We examined potentially important effect modifiers on the outcomes measured, looking in particular (where data were available) for the effects of: type of intervention, timing of intervention, and whether the interventions also included training for clinicians.

\section{Search methods for identification of studies}

\section{Electronic searches}

We used an explicit search strategy agreed with the Cochrane Consumers and Communication Group to search the following databases from their start date:

- Cochrane Central Register of Controlled Trials

(CENTRAL, The Cochrane Library, issue 3, 2006);

- MEDLINE (Ovid) (1966 to September 2006);

- EMBASE (1980 to September 2006);

- PsycINFO (1985 to September 2006);

- ERIC (1966 to September 2006); 
- CINAHL (1982 to September 2006).

The search strategy was adapted for the requirements of each database. We conducted the searches in English, but considered citations identified in any language. We initially ran the searches in January 2004 and updated them in September 2006.

The search strategy for MEDLINE (Ovid) is presented in Appendix 1.

\section{Searching other resources}

We inspected the reference lists of possibly-included studies to identify further potentially-relevant citations. In addition, in an attempt to identify unpublished studies, we wrote to authors of included studies asking for information about similar studies not identified by our search and selection process. We also reviewed in detail the reference lists of five reviews on related topics (Anderson 1991; Cegala 2003, Gaston 2005; Harrington 2004; Jahad 1995). Finally, since it was the journal in which the largest proportion of possibly-included studies were published, we also handsearched the contents of Patient Education and Counseling from 1986 to September 2006 (including those articles listed as being 'in press').

\section{Data collection and analysis}

\section{Consumer involvement}

Before conducting the review, the protocol was submitted to two groups of consumers (University of Wales College of Medicine Simulated Patients and Cochrane Consumer and Communication Review Group consumer representatives) and other peer-reviewers, and modified in the light of feedback.

\section{Selection of studies}

For the electronic searches, two researchers (PD and HP, DO or NC) independently reviewed each title and, where electronically available, the abstract. We categorised citations into three groups: 1) background literature; 2) possibly included studies; and 3) excluded (clearly irrelevant) studies.

Two authors (PK and HP or DO) reviewed independently the full text of the possibly-included studies, and determined whether they met the review's inclusion criteria (stated previously). Disagreements were resolved by discussion, or by seeking a third opinion (AE).

Two members of the research team (PK and RR or NC) independently extracted the data from each study. Disagreements were resolved by discussion. We attempted to contact all authors to establish whether further data from studies were available, and to clarify any difficulties with interpretation or data extraction. When available, this additional data has been presented. We used piloted, specially-developed data extraction forms. Fields included: author; year; country; setting (primary/secondary care); description of intervention; patient groups; clinician groups; disease area; inclusion/exclusion criteria; numbers eligible/approached/recruited/ followed up; randomisation; outcomes; blinding of assessor; duration of follow up; results and comments. Where studies used combined interventions (for example, written materials and coaching) we used data on the effects of the combined intervention for the principal outcomes. However, we used the effects of separate elements of the intervention in secondary analyses (for example, comparing the effects of written materials to coaching).

\section{Avoidance of bias/criteria for assessing quality}

In order to make an evaluation of study quality we assessed studies for: (1) selection bias, (2) performance bias, (3) attrition bias, and (4) detection bias (Clarke 2003). In addition, we gathered data on the adequacy of randomisation with particular attention to concealment of allocation. We reported allocation concealment in the Characteristics of included studies table using the following classification scheme: (A) Adequate, (B) Unclear, (C) Inadequate, or (D) Not used. We used intention-to-treat analyses if available.

\section{Methods for combining studies}

We conducted a narrative synthesis of the included trials, presenting their characteristics and results, focusing in particular on the effects of similar interventions. Since the studies were reasonably similar in terms of settings, inclusion criteria and interventions, we pooled data across studies and conducted meta-analyses where appropriate data were available. We conducted planned subgroup analyses to examine the possible effects of the type of intervention (written materials compared to coaching), and post-hoc analyses to examine the timing of the interventions (some time before the consultation compared to immediately before the consultation) and whether or not the clinicians in the study had received additional training as to how to deal with patients' questions. These were performed to provide further evidence to inform the implementation of future interventions. In the analyses we used the data reporting the effects of appropriate components of the intervention.

We used statistical tests for heterogeneity between studies. To estimate effects we used fixed-effect models where there was homogeneity, and random-effects models where heterogeneity existed. For those outcomes which were measured using the same methods and units we used the weighted mean difference (WMD) method (Higgins 2006). For outcomes measured using differing methods, (for example, satisfaction), or where there was likely to be variation due to the context (for example, consultation length, or questions asked) we used the standardised mean difference (SMD) method (Higgins 2006). 


\section{R E S U L T S}

\section{Description of studies}

See: Characteristics of included studies; Characteristics of excluded studies.

The search strategy generated 4876 citations. From these, the review authors identified 71 citations for possible inclusion. Eleven citations were added from the review by Cegala (Cegala 2003) and eleven from additional reading and citations of reviewed articles. In addition, as the review was proceeding, three further citations were added from the review by Harrington (Harrington 2004), four from handsearching Patient Education and Counseling, and six from further reading. We then assessed this final set of 106 citations. Of this set we excluded 71 papers. We included 33 trials described in 35 papers. The total number of patients randomised and entered into the studies was 8244 . Three of the included studies were reported in more than one paper (Cegala 2000; McCann 1996; Roter 1977); also, two papers (Sander 1996; Thompson 1990) each reported two trials, and are thus labelled Sander 1996a and Sander 1996b; Thompson 1990a and Thompson 1990b.

The main characteristics of the 33 studies, including participants, interventions and outcomes measured, are described in the table 'Characteristics of included studies' . All were published in English. Seventeen studies were from the USA, seven from the UK, four from Australia, two from the Netherlands, two from Canada and one from Indonesia. There appeared to be increasing interest in the subject over time, with one study published in the 1970s, 3 published in the 1980s, 15 in the 1990s and 14 after 1999. The studies varied in size, with 2 studies involving less than 50 patients, 6 studies involving between 50 and 100 patients, 15 involving 100 to 200 patients and 10 involving over 200 patients. In addition, the number of clinicians varied, with 10 studies involving less than 5 clinicians, 4 studies involving between 5 and 9 clinicians, and 10 studies with 10 or more clinicians. In nine studies it was unclear how many clinicians were involved.

The patient population varied. Thirteen studies reported on primary care or family medicine patients, nine reported on patients with cancer, two on patients with diabetes, two on patients with cardiac problems, two on patients with obstetric or gynaecological problems, one on mixed outpatients, one on women attending family planning clinics, one on women attending a well baby clinic, one on children attending a paediatric clinic and one on patients with peptic ulcers. In the study conducted in a paediatric setting, both children and their parents received interventions (Lewis 1991). In one study, some of the patients were inpatients, although they subsequently had an additional outpatient consultation (Butow 1994). Thirty studies reported on patients consulting physicians, two on patients consulting either physicians or nurses, and one on family planning care providers.

\section{Interventions}

The studies assessed a range of interventions, with some studies using multiple or combined interventions of varying complexity. Additional Table 1 provides further information on the interventions, with studies grouped by time of implementation of the intervention, and by level of complexity (single / combined interventions).

With regard to the interventions targeted at patients, 26 studies reported on single interventions and 7 reported on multiple interventions.

\section{Studies assessing single interventions for patients}

Of the single interventions, 20 had only one component and 6 had multiple components. The single component interventions were:

- written materials in 15 studies (Bolman 2005; Brown 2001; Bruera 2003; Butow 1994; Butow 2004; Fleissig 1999; Frederickson 1995; Hornberger 1997; Maly 1999; Martinali 2001; McCann 1996; Middleton 2006; Tabak 1988; Thompson 1990a; Wilkinson 2002);

- coaching in four studies (Finney 1990; Greenfield 1985; Greenfield 1988; Roter 1977); and

- an audiotape of the previous consultation in one study (Ford 1995).

The multiple component (single) interventions were:

- coaching and written materials in four studies (Davison 1997; Kim 2003; Oliver 2001; Tennstedt 2000);

- coaching and a computer programme in one study (Davison 2002); and

- coaching, written materials and a video in one study (Lewis 1991).

\section{Studies assessing multiple interventions for patients}

Of the seven studies assessing multiple interventions:

- one study compared written materials with written materials and coaching (Brown 1999);

- one study compared written materials with brief advice on question asking (Cegala 2000);

- one study compared a brief message about question asking with an interview to identify questions and a third intervention of coaching (Kidd 2004);

- two studies compared two different forms of written materials (Little 2004; Sander 1996a);

- one study compared two different forms of coaching (Sander 1996b); and

- one study compared written materials with a brief message about question asking (Thompson 1990b).

All seven studies had an additional group who received usual care or a dummy intervention. 


\section{Intervention timing}

In 26 of the 33 studies, the interventions were delivered to the patients in the waiting room immediately before their consultation. In six studies the intervention was delivered some time before the consultation - by post in five studies (Bolman 2005; Butow 2004; Fleissig 1999; Martinali 2001; Wilkinson 2002) and by community-based training in one study (Tennstedt 2000). In one study one group of patients received the intervention (a booklet to help them identify and ask questions) by post a few days before the consultation, and a second group of patients received a different intervention (brief advice about question asking) at the clinic on the day of the consultation (Cegala 2000).

\section{Comparisons}

In 20 studies, the control patients received a dummy intervention intended to be similar in length to that being studied, and in 11 studies they received only usual care. In one study (Kidd 2004) there were two control groups with one receiving a dummy intervention and the other usual care. Little 2004 used a 2 x 2 design testing two interventions with one group receiving neither and acting as a control. In three studies the interventions were repeated at subsequent consultations to the same patients (Bolman 2005; Greenfield 1988; Maly 1999).

\section{Interventions for clinicians}

In five studies (Bolman 2005; Brown 1999; Brown 2001; Lewis 1991; Middleton 2006) the clinicians also received an intervention intended to improve their ability to elicit questions from the patient and/or to enable them to answer patients' questions more effectively. In Bolman 2005 all clinicians were trained before the patient interventions were implemented. In Lewis 1991 only those clinicians who were seeing patients who received the intervention received training. Brown 1999 trained clinicians to address the patients' list of questions (if they had them). In Brown 2001 clinicians were randomised to address or to not address the question lists of patients who had received the intervention (that is, half of the patients who received a prompt sheet saw a doctor who actively endorsed the sheet and systematically reviewed each question). Finally, Middleton 2006 used a 2 x 2 design, with patients and clinicians being randomised to interventions.

\section{Outcomes}

We extracted data on all reported outcomes (See additional Table 2; and Table 3).

Our primary focus is on seven important and commonly-reported outcomes (question asking; patient participation; anxiety; patient satisfaction; knowledge; consultation length and clinician satisfaction) which are categorised into the outcome domains specified earlier, as follows:
1. Consultation process: question asking; patient participation;

2. Consultation outcomes:

a) Patient health outcomes: anxiety (primary outcome);

b) Patient care outcomes: patient satisfaction, knowledge (secondary outcomes); and

3. Service outcomes: consultation length, clinician satisfaction. It should be noted that consultation length could be considered both to be a measure of consultation process and an outcome. However, for the purposes of this review, we chose to categorise it as an outcome of particular relevance to clinicians and the service itself.

We conducted meta-analyses on five outcomes: question asking, anxiety, patient satisfaction, knowledge and consultation length. We did not meta-analyse clinician satisfaction, since different methods were used to measure it in the three studies in which it was reported (Bruera 2003; Hornberger 1997; Lewis 1991). We did not meta-analyse patient participation because there was no consistency of measurement in patient questionnaires, and because some studies assessed it from patient questionnaires while others used consultation audiotapes.

Consistent methods of data collection were used across studies (see table Characteristics of included studies). Seventeen studies audiotaped or videotaped patient consultations to measure features of the conversation between patient and clinician (most commonly question asking and consultation length). Twenty six studies used exit questionnaires given to the patients immediately after the consultation to be completed on the premises or to be returned by post, while 14 studies used postal questionnaires or phone interviews to follow up patients days or weeks after their consultations.

\section{Consultation process}

Question asking was measured in 17 studies (Brown 1999; Brown 2001; Bruera 2003; Butow 1994; Butow 2004; Cegala 2000; Fleissig 1999; Ford 1995; Greenfield 1985; Greenfield 1988; Kidd 2004; Kim 2003; McCann 1996; Roter 1977; Tabak 1988; Thompson 1990a; Thompson 1990b) using direct counts from an audiotape.

Participation was measured in 14 studies (Bolman 2005; Butow 2004; Cegala 2000; Fleissig 1999; Ford 1995; Greenfield 1985; Greenfield 1988; Kim 2003; Lewis 1991; Martinali 2001; Roter 1977; Sander 1996a; Sander 1996b; Tennstedt 2000). Eight studies measured it from audiotapes of consultations (Butow 2004; Cegala 2000; Ford 1995; Greenfield 1985; Greenfield 1988; Kim 2003; Lewis 1991; Roter 1977) and six used a range of patient questionnaires (Bolman 2005; Fleissig 1999; Martinali 2001; Sander 1996a; Sander 1996b; Tennstedt 2000).

\section{Consultation outcomes}

a) Patient health outcomes 
Patient anxiety was measured in 12 studies, 8 of which used the Spielberger questionnaire (Bolman 2005; Brown 1999; Brown 2001; Butow 2004; Davison 1997; Martinali 2001; Thompson 1990a; Thompson 1990b). The Hospital Anxiety and Depression Questionnaire was used in three studies (Ford 1995; Hornberger 1997; Little 2004), while Lewis 1991 used the Children's Picture Test of Anxiety to measured anxiety in children . In seven studies, anxiety was measured before the index consultation either as a baseline measure or an assessment of the impact of the intervention (Bolman 2005; Brown 1999; Brown 2001; Butow 2004; Davison 1997; Ford 1995; Martinali 2001). Anxiety was measured after the consultation in 10 studies (Brown 1999; Brown 2001; Butow 2004; Davison 1997; Ford 1995; Hornberger 1997; Lewis 1991; Little 2004; Thompson 1990a; Thompson 1990b).

\section{b) Patient care outcomes}

Patient satisfaction was measured in 23 studies. Four studies used questionnaires based on that developed by Roter (Roter 1977): Brown 1999; Brown 2001; Butow 1994; Butow 2004. Another four studies used methods based on the Medical Interview Satisfaction Scale (Finney 1990; Lewis 1991; Little 2004; McCann 1996). The remaining 15 studies used a variety of methods (Bolman 2005; Bruera 2003; Davison 2002; Fleissig 1999; Greenfield 1985; Greenfield 1988; Hornberger 1997; Kidd 2004; Maly 1999; Martinali 2001; Middleton 2006; Roter 1977; Tennstedt 2000; Thompson 1990a; Thompson 1990b).

Patient knowledge was measured in five studies. Two studies used the same questionnaire for patients with heart problems (Bolman 2005; Martinali 2001), and the remaining three studies each used different instruments (Greenfield 1985; Greenfield 1988; Oliver 2001).

\section{Service outcomes}

Consultation length was measured in 17 studies; in 11 directly from audiotape (Brown 2001; Bruera 2003; Butow 1994; Butow 2004; Ford 1995; Greenfield 1985; Greenfield 1988; Hornberger 1997; Kim 2003; McCann 1996; Roter 1977), and in 6 by other methods (Bolman 2005; Little 2004; Maly 1999; Martinali 2001; Middleton 2006; Thompson 1990a). The unit of measurement for consultation length in all studies was minutes.

As stated earlier, clinician satisfaction was measured in three studies using various methods (Bruera 2003; Hornberger 1997; Lewis 1991).

\section{Risk of bias in included studies}

The studies were of variable quality, with more rigorous methods tending to be used in more recently published papers.

\section{Study design}

All of the included studies were described as randomised controlled trials. However, methods of randomisation were described only briefly. In 27 studies the information was very brief, using terms such as 'patients were randomly allocated' or 'patients were randomly given an envelope' (Bolman 2005; Brown 1999; Bruera 2003; Butow 1994; Butow 2004; Cegala 2000; Davison 1997; Davison 2002; Finney 1990; Frederickson 1995; Greenfield 1985; Greenfield 1988; Hornberger 1997; Kidd 2004; Kim 2003; Lewis 1991; Martinali 2001; McCann 1996; Oliver 2001; Roter 1977; Sander 1996a; Sander 1996b; Tabak 1988; Tennstedt 2000; Thompson 1990a; Thompson 1990b; Wilkinson 2002). In two studies computers were used to generate random numbers (Brown 2001; Fleissig 1999); two studies used random number tables (Little 2004; Middleton 2006); one study used a remote trials coordination centre (Ford 1995); and one study used a card shuffling technique (Maly 1999).

In 30 studies, randomisation was by patient. In two studies, randomisation was by clinician (Hornberger 1997; Lewis 1991) and in one by site of delivery of a community-based intervention (Tennstedt 2000). In these three latter studies no attempt was made to account for the effects of clustering, which can lead to overestimation of the significance of the intervention. To explore this we conducted post-hoc meta-analyses with and without data from these studies and have described the results.

Only six studies provided sample size calculations (Bolman 2005; Brown 1999; Brown 2001; Kidd 2004; Little 2004; Middleton 2006).

\section{Method of allocation concealment}

Only four trials provided sufficient evidence of adequate concealment of allocation (Ford 1995; Little 2004; Middleton 2006; Tabak 1988). The methods used included an external trials coordination centre (Ford 1995), numbered, pre-prepared, sealed, opaque envelopes (Little 2004), and randomisation of appointment slots with blinding of receptionists (Middleton 2006). Twenty four studies were judged to be unclear about the method of allocation concealment, usually because insufficient information was provided. There was insufficient blinding of allocation in five studies (Cegala 2000; Frederickson 1995; Maly 1999; Sander 1996b; Tennstedt 2000).

\section{Protection against contamination}

In the two studies which were randomised by clinician ( Hornberger 1997; Lewis 1991), no particular steps seem to have been taken to prevent contamination between clinicians in the different study arms. In addition, in Brown 2001 in which clinicians were randomly selected for training to address the intervention, there was a risk of contamination between trained and non-trained clinicians and also the possibility that trained clinicians might use 
their training with patients who had not received the intervention (the trained clinicians were required to actively endorse the list of questions for those patients who had received a prompt sheet). Evidence was provided that the clinicians did vary their consulting style appropriately and did not overly facilitate questions with patients who had not received the prompt sheet.

\section{Blinding of outcome assessors}

In the 17 studies that used audio or videotapes to gather data about the consultation, 7 studies (Bruera 2003; Cegala 2000; Finney 1990; Greenfield 1985; Greenfield 1988; Kidd 2004; Tabak 1988) reported that those who assessed the tape were blind to patients' group allocation. In addition, 8 studies (Brown 2001; Butow 2004; Cegala 2000; Ford 1995; Greenfield 1985; Greenfield 1988; Hornberger 1997; Kidd 2004) reported reliability checks on the gathering of this data, with double rating of a sample or of all tapes. Most studies were unclear about the blinding of assessors for other key outcomes. However as most studies used patientreported measures (questionnaires), there may be low risk of ascertainment bias.

\section{Use of intention-to-treat analyses}

Only two studies stated they used intention-to-treat analyses ( Brown 2001; Little 2004).

\section{Effects of interventions}

Additional Table 2 'Main outcomes for each study' shows the effects of interventions on the outcomes measured in each study, classified as reduced, no change, or increased. These descriptors reflect statistical significance; that is, a statistically significant reduction in anxiety is labelled 'reduced' while a statistically insignificant reduction is labelled 'no change'

Additional Table 3 'Summary of outcomes sought' outlines the outcomes we looked for and the number of studies which reported them. We sought but did not find data on outcomes including: patients' satisfaction with knowledge provision, confidence and ability to cope, lifestyle or behavioural outcomes, use of health services, provision of information, clinicians' perceptions of the intervention, and, importantly, harms.

The most commonly-used measures of consultation process were question asking and patient participation. Primary consultation outcome measures - patient health outcomes - were measured rarely apart from psychological health. We have summarised below secondary consultation outcome measures of patient care patient satisfaction and knowledge. The service outcome, consultation length, is also summarised below.

Meta-analyses were undertaken for the outcomes of: patient question asking (Analysis 1.1), patient anxiety (before and after the index consultation (Analysis 1.2; Analysis 1.3)) patient satisfaction
(Analysis 1.4), knowledge (Analysis 1.5; Analysis 1.6), and consultation length (Analysis 1.7), where studies or authors provided appropriate data.

Additional analyses examined the effect of the type of intervention (written materials versus coaching), timing of interventions (some time before the index consultation versus immediately before the index consultation) and co-interventions (training for clinicians) for the same outcomes. However, for patient anxiety and knowledge there were insufficient studies in particular groups to undertake these further analyses, and for question asking it was only possible to investigate the effects of the type of intervention. To help with the interpretation of our findings, we considered effect sizes of around 0.2 to be 'small', 0.5 'moderate' and 0.8 or greater 'large' (Cohen 1988).

\section{Consultation process}

\section{Question asking}

With regard to consultation process outcomes, 17 studies measured question asking in the consultation, with 6 studies finding statistically significant increases (Brown 1999; Butow 2004; Cegala 2000; Kim 2003; Roter 1977; Thompson 1990a), and 11 studies finding no effects of the interventions compared to the controls (Brown 2001; Bruera 2003; Butow 1994; Fleissig 1999; Ford 1995; Greenfield 1985; Greenfield 1988; Kidd 2004; McCann 1996; Tabak 1988; Thompson 1990b).

The meta-analysis (Analysis 1.1) shows a small and statistically significant increase in patient question asking (SMD 0.27 (95\% CI 0.19 to 0.36). It should be noted that for the study by Roter (Roter 1977), we had to make two assumptions about the data; first, that the number of people analysed in the interventions and the control groups for the outcomes of question asking and patient satisfaction were equal, and second, that for patient satisfaction the means for the two groups were 1.46 and 1.37 , and not 146 and 1.37 as stated in the text.

\section{Patient participation}

Patient participation in the consultation was measured in a variety of ways in 14 studies (Bolman 2005; Butow 2004; Cegala 2000; Fleissig 1999; Ford 1995; Greenfield 1985; Greenfield 1988; Kim 2003; Lewis 1991; Martinali 2001; Roter 1977; Sander 1996a; Sander 1996b; Tennstedt 2000). It was increased by the interventions in eight studies (Butow 2004; Cegala 2000; Fleissig 1999; Ford 1995; Greenfield 1985; Greenfield 1988; Kim 2003; Lewis 1991), with no effect in five studies (Martinali 2001; Roter 1977; Sander 1996a; Sander 1996b; Tennstedt 2000). In Bolman 2005 participation was found to be increased after the first consultation and decreased in a second and third consultation. 


\section{Consultation outcomes}

\section{a) Patient health outcomes: anxiety}

Anxiety is reported by the time of its measurement, either before or after the consultation.

With regard to primary consultation outcomes, patients' mental health was measured in the form of anxiety in 12 studies. In seven studies anxiety was measured before the index consultation (Bolman 2005; Brown 1999; Brown 2001; Butow 2004; Davison 1997; Ford 1995; Martinali 2001), but in three studies this was at the same time as the intervention (Brown 1999; Brown 2001; Davison 1997), so we considered it inappropriate to use this measurement as an outcome since it was intended as a baseline measure. However in four studies, the interventions were delivered some time before the consultation and anxiety was measured when the patient arrived for the consultation (Bolman 2005; Butow 2004; Ford 1995; Martinali 2001); in these studies we considered the assessment to be a true measure of the effects of the intervention. Two studies which measured anxiety before the consultation found it to be reduced (Bolman 2005; Martinali 2001), one found it unchanged (Ford 1995) and one study found it increased (Butow 2004).

The meta-analysis (Analysis 1.2) showed a large decrease in patient anxiety before consultations, but this result was not statistically significant (WMD -1.56 (95\% CI -7.10 to 3.97)).

In the nine studies measuring anxiety after the index consultation, one study found an increase in anxiety (Brown 2001) two found decreases (Hornberger 1997; Thompson 1990a) and the other six studies found no effect (Brown 1999; Brown 2001; Butow 2004; Davison 1997; Ford 1995; Hornberger 1997; Lewis 1991; Little 2004; Thompson 1990a; Thompson 1990b). The meta-analysis (Analysis 1.3) showed a small and statistically insignificant decrease in patient anxiety after consultations (SMD -0.08 (95\% CI - 0.22 to 0.06$)$ ).

\section{b) Patient care outcomes: Patient satisfaction}

Patient satisfaction was measured in 23 studies. In 14 studies there were no changes (Bolman 2005; Brown 1999; Brown 2001; Bruera 2003; Butow 1994; Butow 2004; Davison 2002; Greenfield 1985; Greenfield 1988; Hornberger 1997; Martinali 2001; McCann 1996; Middleton 2006; Thompson 1990a), and in 5 there was increased satisfaction (Fleissig 1999; Little 2004; Maly 1999; Roter 1977; Thompson 1990b). In two studies there were only increases for particular aspects of satisfaction (depth of relationship (Middleton 2006), interpersonal satisfaction (Tennstedt 2000)). In Lewis 1991 child satisfaction increased but parent satisfaction was unchanged (we used the data on parent satisfaction in the meta-analyses, since all other patient groups were adults) and in Kidd 2004 there was no immediate change in satisfaction, but it was increased at three months post intervention.
The meta-analysis (Analysis 1.4) shows a small and statistically significant increase in patient satisfaction (SMD 0.09 (95\%CI 0.03 to 0.16$)$ ).

Patient satisfaction was affected by the type of intervention and its timing (see below).

\section{Patient knowledge}

With regard to secondary outcomes, patient knowledge was measured in five studies with reductions in two studies (Bolman 2005; Greenfield 1985) and no change in three studies (Greenfield 1988; Martinali 2001; Oliver 2001). However, in two studies we considered that the placebo intervention for the control group was likely to increase patients' knowledge of their condition, because it also included information about their condition (Greenfield 1985; Martinali 2001).

The meta-analysis (Analysis 1.5) shows a small and not statistically significant decrease in knowledge (SMD - 0.34 (95\% CI -0.94 to $0.25)$ ). We repeated the analysis omitting Greenfield 1985 and Martinali 2001 (Analysis 1.6) and still found a small and not statistically significant decrease in knowledge (SMD - 0.26 (95\% CI -0.52 to 0.01$)$ ).

\section{Service outcomes}

\section{Consultation length}

Seventeen studies measured consultation length with 3 studies (Hornberger 1997; McCann 1996; Middleton 2006) finding statistically significant increases in consultation length and 13 studies (Brown 2001; Bruera 2003; Butow 1994; Butow 2004; Ford 1995, Greenfield 1985; Greenfield 1988; Kim 2003; Little 2004; Maly 1999; Martinali 2001; Roter 1977; Thompson 1990a) finding no effect. The study by Bolman (Bolman 2005) found that the first of three linked consultations was reduced in length, while the third consultation was increased.

The meta-analysis (Analysis 1.7) shows a small and not statistically significant increase in consultation length (SMD 0.10 (95\% CI 0.05 to 0.25$)$ )

Consultation length was affected by the type of intervention and its timing (see below).

\section{Clinician satisfaction}

In three studies (Bruera 2003; Hornberger 1997; Lewis 1991) clinician satisfaction was measured, but with no notable effects identified. No meta-analysis was conducted for this outcome. With regard to other outcomes, there were no consistently positive effects. 


\section{Types of intervention (written materials and coaching)}

\section{Question asking}

With regard to the effects of different types of intervention, for the comparison between written materials alone and coaching alone there were similar, small to moderate and statistically significant increases for both types of intervention for the outcome of question asking (Analysis 2.1) (written materials SMD 0.42 (95\% CI 0.26 TO 0.59); coaching SMD 0.36 (95\% CI 0.16 to 0.56$)$ ).

\section{Patient satisfaction}

For patient satisfaction (Analysis 2.2), written materials produced a small increase which was borderline for statistical significance (SMD 0.08 (95\% CI 0.00 to 0.16$)$ ), whereas for coaching the effect was small and statistically significant (SMD 0.23 (95\% CI 0.08 to 0.38$)$ ).

\section{Consultation length}

For the outcome of consultation length (Analysis 2.3), written materials led to a small and statistically significant increase in consultation length (SMD 0.13 (95\% CI 0.05 to 0.21$)$ ), whereas for coaching there was a smaller increase in consultation length which was not significant (SMD 0.07 (95\% CI -0.07 to 0.20$)$ ).

\section{Timing of the intervention}

For the effects of timing of the intervention, there were only two studies with extractable data in which the interventions were conducted some time before the consultation (Bolman 2005; Martinali 2001).

\section{Patient satisfaction}

For patient satisfaction (Analysis 3.1), interventions immediately before the consultation led to a small and statistically significant increase in patient satisfaction (SMD 0.10 (95\% CI 0.02 to 0.17$)$ ) whereas those interventions given some time before the consultation led to a small and not significant change (SMD 0.07 (95\% CI -0.20 to 0.34$)$ ).

\section{Consultation length}

Similarly for consultation length (Analysis 3.2), interventions immediately before the consultation led to a small and statistically significant increase in consultation length (SMD 0.16 (95\% CI 0.03 to 0.29$)$ ), whereas those some time before the consultation led to no change (SMD -0.04 (95\% CI -0.93 to 0.86)).

\section{Clinician training}

For the effects of clinician training, there were two possible analyses to be considered. First, whether clinician training combined with interventions targeted at patients provided greater benefits than interventions targeted at patients alone. Since we considered this comparison to be of prime interest to those wanting to improve services to patients, we conducted a meta-analysis of these data (Analysis 4.1; Analysis 4.2).

Three studies contained usable data of combined interventions for the outcomes of patient satisfaction and consultation length (Brown 2001; Lewis 1991; Middleton 2006).

\section{Patient satisfaction}

Meta-analysis showed that additional clinician training had no effect on patient satisfaction (Analysis 4.1) when interventions were combined with clinician training (SMD -0.01 (95\%CI -0.15 to 0.12$)$ ) compared with patient interventions alone which had a small effect (SMD 0.13 (95\%CI 0.05 to 0.21$)$ ).

\section{Consultation length}

We found the same effects on consultation length in studies where there was additional clinician training as in studies where there was no clinician training (Analysis 4.2). In both types of study there was little impact on consultation length (studies with clinician training SMD 0.17 (95\% CI 0.01 TO 0.32); studies without clinician training SMD 0.17 (95\%CI 0.10 to 0.24$)$ ).

An alternative approach is to consider the impact of patient interventions in the context of the clinicians also receiving training (that is, all clinicians being trained so that patients from both control and intervention groups saw trained clinicians). For this analysis, two studies contained relevant data (Bolman 2005; Middleton 2006). Bolman 2005 showed that the patient intervention produced a small decrease in consultation length (SMD -0.49 (95\%CI - 0.88 to -0.10$)$ ) and had no effect on patient satisfaction (SMD 0.00 (95\%CI -0.39 to 0.39$)$ ). Middleton 2006 showed a small increase in consultation length (SMD 0.24 (95\%CI -0.05 to 0.43$)$ ), and very little effect on patient satisfaction (SMD 0.03 (95\%CI -0.16 to 0.22$)$ ).

From these two analyses we conclude, from the limited evidence available, that there are no clear benefits from clinician training, either combined with patient interventions or before the implementation of patient interventions.

Three studies were randomised by clinician (Hornberger 1997; Lewis 1991; Tennstedt 2000). These cluster randomised trials may have overestimated the effects found. We re-calculated the effect sizes and confidence intervals without these studies, and found small changes to the reported results (Additional Table 4). It should be noted that other studies may have also been vulnerable to clustering effects, and reported standard errors and confidence intervals may be overestimates. 


\section{DISCUSSION}

Patients still do not get the information they require in clinical consultations (Rogers 2005). This review identified 33 randomised trials, in a range of settings and countries, of interventions designed to address this challenge which were targeted at patients. Our meta-analyses show that although the individual effects found in particular trials may be small or non-significant, when combined there are small and statistically significant effects in terms of increased patient question asking and increased patient satisfaction. The result for patient anxiety before consultations demonstrated a large, but not statistically significant, effect. Results for patient anxiety after consultations and consultation length were also small and not statistically significant. The effects of the interventions on patient knowledge are unclear due to methodological difficulties. Assessing patient participation remained a challenge throughout the review; although commonly measured, a range of methods are used (from tapes of consultations and from patient questionnaires); additionally, participation could mean different things to different people.

\section{Question asking}

The increase in question asking demonstrates the most direct effect of the interventions. Patients were asked, largely through written messages or coaching, to identify questions, and told that the clinicians were interested in the patients asking these questions and would try to provide information. While increased question asking in itself may be of little direct benefit to patients or clinicians, these findings demonstrate that relatively straight forward interventions are able to influence the dialogue between clinician and patient, albeit to a small degree. However, the interventions may be expected to have greater direct effects. A possible explanation for this is that many clinicians, and probably patients, adopt 'ritual' styles of consulting (Neighbour 1996), and these may not readily be changed by interventions, particularly if delivered immediately before the consultation and only targeted at one participant in the consultation (as most of these interventions were). Unfortunately, we did not have the data to explore whether question asking increased more when the clinicians were trained. In addition, desire for information by patients may not necessarily translate into question asking (Beisecker 1990). As a result, while the interventions may have helped patients to identify questions to ask, patients may have been unable to ask them, and may have left with the questions unanswered (Butow 2004; Fleissig 1999). Another possibility is that the doctor may have given the information unprompted and in trials randomising by patient there is the real possibility that clinicians may start giving more information to all patients, and not only those who asked questions. This could minimise the effects found for all outcomes; not just question asking. It should also be noted that most studies using this outcome focused on the number of questions asked, rather than the type of questions or topics raised. It would be hoped that the increase in number of questions indicated that the patient was able to address important information needs. This is supported by Brown's finding of an increase in the number of questions about prognosis in patients with cancer (Brown 2001). Prognosis would clearly be a topic of great significance in this patient group, but also could be an issue that patients might be reluctant to address without specific encouragement (Fleissig 2000; Leydon 2000).

\section{Patient anxiety}

The tentative finding of a reduction in patient anxiety before consultations indicates the most sizeable effect of the interventions. However, this result did not reach statistical significance and the number of studies and patients involved is small (3 studies involving 372 patients). Patients attending consultations feel they have a story to tell and questions to which they want answers (Helman 2007). However, they may feel uncertain as to whether they will get the chance to express their needs and get the information they seek. It would appear that the interventions reviewed here may act as an acknowledgement to the patients that their concerns will be heard and that they will get their questions answered. In addition, helping patients to organise their thoughts and plans for the consultation is likely to be an effective strategy for reducing anxiety. It should be noted, however, that the study by Butow which involved patients with cancer showed an increase in patient anxiety (Butow 2004), which suggests that the effects may be different with particular patient groups. It is also notable that Bolman found that fewer patients used the intervention at successive consultations and that pre-consultation anxiety increased before each successive consultation in both the control and intervention groups (Bolman 2005). This suggests that rather than patients becoming familiar with the physicians at the clinic and feeling less need to organise themselves, they were finding that the clinicians were relatively unresponsive to their questions and thus there was little to be gained from the process. Support for this possibility comes from the finding that anxiety after consultations was not similarly reduced. It might be hoped that the interventions would give patients a greater sense of control within the consultations as they would be more organised about their concerns and more assertive. In addition, they would have identified and in some cases practised asking the questions they wanted to ask to alleviate their concerns. However, anxiety may not consequently be reduced for two possible reasons. First, the clinician may not respond helpfully, thus frustrating the patient's attempts to gather information or, second, the information provided as a result of the increased question asking may be worrying. This would be particularly likely in oncology clinics (in which nine studies were set).

\section{Patient satisfaction}


The small increase in patient satisfaction indicates another benefit of these interventions. Satisfaction is a commonly measured outcome for consultations and has itself been related to other beneficial outcomes. The increase found here is consistent with other reports of increased patient satisfaction with more patient-centred styles of consulting (Kinnersley 1999; Krupat 2000; Lewin 2001). However, increased satisfaction may not be an automatic benefit of increased question asking by patients. Roter suggests that increased question asking by the patient changes the patient's role and the consultation process, thus disrupting the usual consultation 'harmony' (Roter 1977). Indeed, the interventions could even generate conflict, between patients expecting answers to questions and clinicians used to providing relatively limited information. As a result, satisfaction may not be increased - as anxiety may not be reduced - if the expectations generated by the intervention are not fulfilled by the subsequent consultation. It has been suggested that the interventions would probably have had more effect if endorsed by the clinicians or supported by clinician training, as some patients reported not feeling comfortable referring to their question list during consultations (Butow 2004; Fleissig 1999; Roter 1977). Although this advice has only been followed in a small number of studies in this review, those studies in which the clinicians received training had less impact on patient satisfaction than those in which the clinicians were not trained. This may be because the clinician training was inadequate or ineffective; certainly it appears to have been quite brief in most reports (Brown 1999).

\section{Consultation length}

The finding that the effects of interventions on consultation length were small and not statistically significant is important, as clinicians and healthcare providers will be understandably cautious about interventions which they may expect to increase consultation length. It is notable that written materials increased consultation length but coaching did not. This suggests that coaching has the advantage that patients can be guided as to how to ask questions efficiently, which would be more difficult with written materials (since both seem equally effective in terms of increasing patient question asking). It is more difficult to interpret the effect of timing of intervention and clinician training but it would appear that even when the effects are statistically significant their size is small. Clearly how clinician and patient spend the consultation time is likely to be as important as the amount of time itself (Wilson 2002a).

\section{Patient knowledge}

The effects on patient knowledge are difficult to interpret for two reasons. First, the results of the meta-analysis should be regarded with caution, since in two of the studies the placebo intervention for the control group included information for patients about their condition (Greenfield 1985; Martinali 2001). Secondly, the number of studies using this outcome is small. It would be expected that increased question asking would lead directly to increased patient knowledge and therefore this finding requires further exploration. It should be noted that careful attention to the design of placebo interventions and rigorous attention to other methodological details (such as allocation concealment) will be required.

\section{Types of intervention}

The effects of the different types of interventions (written materials and coaching) are interesting. Although their effects on question asking are similar, coaching led to a greater increase in patient satisfaction with no concomitant increase in consultation length. This may be because whilst both methods are effective in helping the patient generate questions, coaching leads to patients asking more significant questions more efficiently. However, it is also possible that the increase in patient satisfaction is, in some part, a reflection of patients' positive responses to the 'consultation' they have with the coaching provider. These differences are important since coaching is more costly than the provision of written materials, and is probably impractical in many healthcare settings. Further research may be needed to clarify whether the apparent benefits of coaching are sustained if the coaching is delivered some time before, and thus separate from, the consultations.

\section{Timing of intervention}

The effects of the timing of the interventions are mixed, and the meta-analyses must be interpreted with caution given the small number of studies which provided data some time before the consultations. It would appear that interventions employed some time before the consultations may not increase consultation length nor patient satisfaction, while interventions immediately before consultations increase both consultation length and satisfaction. This may be as a result of the small numbers of studies, or it could suggest that patients who attend their consultation having had time to consider their needs have greater expectations which may not be fulfilled. One would expect interventions some time before consultations to be preferable, since this would give patients more time to identify, prioritise and rehearse questions, but they may result in more demanding consultations for clinicians.

\section{Clinician training}

The effects of clinician training are notable. It might be expected that clinician training would lead to greater efficiency in consultations and greater patient satisfaction but in fact we found similar small increases in consultation length between studies with and without clinician training and no effect on patient satisfaction when there was clinician training but a small increase when there 
was no training. However, as already noted the number of studies in which clinicians were trained is small, and the training provided was brief. Studies are needed in which clinicians are trained more intensively to help patients express their information needs and to provide information skilfully. Qualitative studies might also be useful to understand why patients are not satisfied.

\section{Considering patient needs}

Certain patient groups or patients with particular conditions may find the interventions more helpful than others. Many of the studies were in settings in which patients were consulting oncologists. This may reflect oncologists' interest in providing high quality information to patients and therefore in research methods to achieve this, or may be an acknowledgement that patients with cancer have particularly complex information needs (Leydon 2000). However, no single study explored the use of the same intervention in different settings. Cegala (Cegala 2000) and McCann (McCann 1996) assessed the impact of the interventions on different patient groups and found that younger, white, middle-class, educated patients asked more questions. Since younger patients are known to ask more questions generally however, these findings may not indicate a specific effect of the intervention. In addition, it is notable that older, less educated patients did not perceive themselves as being less involved, or to have less control over decision making (Tennstedt 2000).

\section{Size of effect}

For the outcomes studied, the benefits of the interventions are modest. This is not to dismiss the interventions' value, but they do not appear to be the solution to the challenge of improving communication between patients and clinicians. A particular concern is that they represent mechanistic 'quick fixes' which can be readily implemented. This approach is now being advanced by various websites set up to guide patients on how to prepare for consultations. Such resources may be helpful, but focusing on the patient alone (without ensuring the clinician is also receiving guidance) may not produce long-term patient benefits, due to the complexity of the dialogue between patient and clinician (Roter 2000).

\section{Quality of the evidence}

With regard to the validity of our results, we have reviewed a considerable body of research ( 33 trials, 8244 patients). All of these were randomised trials although we note that the information provided about the methods used, particularly in the earlier reports, was limited and often inadequate. Thus there has to be some caution about the quality of the evidence. However, it should also be noted that there was general consistency, in terms of the results found across studies, although for some the confidence intervals are very wide and some meta-analyses show considerable statistical heterogeneity.

\section{Broader relevance of the findings}

A successful consultation requires that the patient, rather than their disease, be the focus of health care (Bensing 2000). Patient and clinician must reach common ground over the nature of the problem and what could and should be done about it (Starfield 1981). Information needs to be exchanged, and decision making shared, and clinicians need to be sufficiently flexible to adapt to the varying preferences of different patients or the same patient in different circumstances (Edwards 2006; Elwyn 1999; Elwyn 2000; Fleissig 2000). Some patients will not want information about their illness, or at least not at that particular consultation, preferring a non-participatory role (Leydon 2000). Furthermore, clinicians may continue to have mixed views of the benefits of increased patient participation in consultations, viewing the encouragement of question asking as threatening when time is limited and their focus is on the medical agenda. Thus a combined approach is required in which patients are encouraged and helped to participate in consultations if they wish, and in which clinicians have the skills to identify and adapt to different patients' needs. Interventions like those for helping patients address their information needs can address part of this approach, but a spiral curriculum of communication skills training for clinicians, from initial generic training to methods that address the needs of specialist roles, has been argued (Silverman 2005). An alternative approach is demonstrated by the use of specialist nurses, who may consult with the patient, as well as accompany the patient when consulting with the specialist physician. In these circumstances, the nurse can provide information directly to the patient and also be an advocate for information gathering or an interpreter of the information provided.

Most studies used multiple outcome measures to assess the effects of interventions and there was generally consistent use of validated measures for certain specific outcomes. Given the apparent ease of audiotaping consultations, estimates (rather than accurate measurements) of patients' question asking or of consultation length by clinicians or patients should not be used. The definition of some outcomes (such as knowledge) requires improved reporting. Furthermore, there was relatively limited attention to outcomes directly related to patients' health, for example symptom control and performance status, with researchers preferring to assess more readily measurable outcomes related to patient care (such as satisfaction).

Clearly it is important to consider the context in which care is being provided when considering patient empowerment. In acute life threatening emergencies, the majority of patients look to clinicians to make decisions and take action, without their active participation. However, when there is clinical uncertainty or in the management of chronic disease, patients need to participate in 
their consultations and be actively involved in their care (Elwyn 1999). This is likely to demand methods of enhancing patient participation as reviewed here, but also requires clinicians having the necessary skills and attitudes to reach common ground and share decisions (Edwards 2006).

\section{Strengths of the review}

Several related reviews have been published (Anderson 1991; Cegala 2003; Harrington 2004; Jahad 1995; Post 2002; Wetzels 2007). This suggests a growing concern with helping patients to participate fully in their consultations. However, we have used a more comprehensive search and review strategy than other reviews, and have identified more trials of interventions directed at patients, despite limiting included studies to those with random allocation of participants. We also contacted and received responses from authors, thus enabling us to clarify or add to the data presented. In addition, to our knowledge no other review on this subject has incorporated meta-analyses. The other reviews are broadly supportive of interventions to promote patient information gathering, identifying a range of beneficial outcomes. However, the data provided by our meta-analyses enable us to provide clearer and more conclusive evidence of the effects of these interventions.

\section{Weaknesses of the review}

Despite our efforts to search comprehensively for relevant studies, we may have omitted some studies. Although we contacted authors, we were only able to identify published trials and it is possible that other relevant trials remain unpublished. Furthermore there may be an English language bias as a result of the databases we searched. However, given the attention paid to this subject in original research and reviews, we believe it is unlikely that any other major study which would have changed our conclusions has been omitted.

We restricted the review to studies involving patients consulting doctors or nurses. It may be that interventions have been tested for patients consulting other health professionals. However, since doctors and nurses are considered by patients as being their main source of information about major illnesses we consider that we have reviewed the most important area of relevant literature.

\section{A U THORS, CONCLUSIONS}

\section{Implications for practice}

The effects of interventions focused on patients prior to their consultations, designed to help them address their information needs within consultations, are small. Since written interventions are likely to be much cheaper than coaching they should be perhaps be used in preference, although they may slightly increase consultation length. Clinicians should continue to try to encourage their patients to ask questions and to provide them with information. Question prompt sheets or coaching may be helpful with particular groups for whom asking questions is particularly difficult, but these interventions do not appear to produce consistent major benefits.

\section{Implications for research}

Despite the relatively large number of similar trials conducted, there appears to be a need for further research to fully evaluate the effects of these types of interventions. While many studies counted the number of questions asked, there were very few assessments of the questions' quality or content. Patients' information needs are specific. Some questions may be more difficult to ask (for example, about prognosis in cancer consultations) and thus may require particular facilitation by the clinician. Additionally, and probably most importantly, further research should explore the effects of the clinicians' responses to question asking by patients, and whether clinician training can enhance this. In the studies reported here, where clinician training occurred it appears to have been ineffective in producing consistent additional benefits. Further trials are needed to establish whether patient-focused interventions combined with intensive training of clinicians can produce overall and sustained benefits. Finally, other outcomes should be considered. As an outcome, patient satisfaction has limitations, since patients may be satisfied with less than ideal care. Alternative outcomes should be considered and tested in randomised trials.

\section{ACKNOWLEDGEMENTS}

We thank the staff and editors of the Cochrane Consumers and Communication Review Group, particularly Megan Prictor for her overall advice and guidance, Sophie Hill as Coordinating Editor of the Review Group, Dell Horey, contact editor for the review and Dominique Broclain, contact editor for the protocol, and former Trials Search Coordinator Judy Stoelwinder for her assistance with the search strategy. We would also like to thank Damien Jolley and Kelly Allen for their statistical feedback and the other anonymous editors and external peer reviewers for their comments. We thank the following consumers for their helpful feedback : from University of Wales College of Medicine Simulated Patients Janine Cooper-Marshall, Pat Oliver, Iris Mackenzie, Peter Palmer, Richard Berry; from Cochrane Consumer and Communication Group consumer representatives Amy Zelmer, Nete Villebro, Rosemary Humphreys, Amy Arkle, Judi Strid. The initial idea for this work came when Paul Kinnersley was working in Australia funded by a grant from the PPP Foundation (now known as the Health Foundation). 


\section{R E F E R E N C E S}

\section{References to studies included in this review}

Bolman 2005 \{published and unpublished data\} Bolman C, Brug J, Bar J, Martinali J, van den Borne B. Long-term efficacy of a checklist to improve patient education in cardiology. Patient Education and Counseling 2005;56:240-8.

\section{Brown 1999 \{published data only\}}

Brown R, Butow PN, Boyer MJ, Tattersall MHN. Promoting patient participation in the cancer consultation: evaluation of a prompt sheet and coaching in question asking. British Journal of Cancer 1999;80:242-8.

Brown 2001 \{published and unpublished data\} Brown RF, Butow PN, Dunn SM, Tattersall MHN. Promoting patient participation and shortening cancer consultations: a randomised trial. British Journal of Cancer 2001;85:1273-9.

Bruera 2003 \{published data only\}

Bruera E, Sweeney C, Willey J, Palmer JL, Tolley S, Rosales M, Ripamonti C. Breast cancer patient perception of the helpfulness of a prompt sheet versus a general information sheet during outpatient consultation: a randomized controlled trial. Journal of Pain and Symptom Management 2003;25:412-21.

Butow 1994 \{published data only\} Butow PN, Dunn SM, Tattersall MHN, Jones QJ. Patient participation in the cancer consultation: evaluation of a question prompt sheet. Annals of Oncology 1994;5: 199-204.

Butow 2004 \{published data only\}

Butow P, Devine R, Boyer M, Pendlebury S, Jackson M, Tattersall MHN. Cancer consultation preparation package: changing patients but not physicians is not enough. Journal of Clinical Oncology 2004;22:4401-9.

Cegala 2000 \{published and unpublished data\} Cegala DJ, Marinelli T, Post D. The effects of patient communication skills training on compliance. Archives of Family Medicine 2000;9:57-64.

* Cegala DJ, McClure L, Marinelli TM, Post DM. The effects of communication skills training on patients' participation during medical interviews. Patient Education and Counseling 2000;41:209-22.

Post DM, Cegala DJ, Marinelli TM. Teaching patients to communicate with physicians: the impact of race. Journal of the National Medical Association 2001;93:6-12.

Davison 1997 \{published and unpublished data\} Davison BJ, Degner LF. Empowerment of men newly diagnosed with prostate cancer. Cancer Nursing 1997;20: 187-96.
Davison 2002 \{published data only\}

Davison BJ, Degner LF. Feasibility of using a computerassisted intervention to enhance the way women with breast cancer communicate with their physicians. Cancer Nursing 2002;25:417-24

Finney 1990 \{published data only\}

Finney JW, Brophy CJ, Friman PC, Golden AS, Richman GS, Ross AF. Promoting parent-provider interaction during young children's health-supervision visits. Journal of Applied Behaviour Analysis 1990;23(2):207-13.

Fleissig 1999 \{published data only\}

Fleissig A, Glasser B, Lloyd M. Encouraging out-patients to make the most of their first hospital appointment: to what extent can a written prompt help patients get the information they want?. Patient Education and Counseling 1999;38:69-79.

Ford 1995 \{published data only\}

Ford S, Fallowfield L, Hall A, Lewis S. The influence of audiotapes on patient participation in the cancer consultation. European Journal of Cancer 1995;31A: 2264-9.

Frederickson 1995 \{published and unpublished data\} Frederickson LG, Bull PE. Evaluation of a patient education leaflet designed to improve communication in medical consultations. Patient Education and Counseling 1995;25: 51-7.

Greenfield 1985 \{published data only\} Greenfield S, Kaplan S, Ware JE. Expanding patient involvement in care: effects on patient outcomes. Annals of Internal Medicine 1985;102:520-8.

Greenfield 1988 \{published data only\} Greenfield S, Kaplan SH, Ware JE, Yano EM, Frank HJL. Patients' participation in medical care: effects on blood sugar control and quality of life in diabetes. Journal of General Internal Medicine 1988;3:448-57.

Hornberger 1997 \{published data only\} Hornberger J, Thom D, MaCurdy T. Effects of a selfadministered previsit questionnaire to enhance awareness of patients' concerns in primary care. Journal of General Internal Medicine 1997;12:597-606.

Kidd 2004 \{published data only\}

Kidd J, Marteau TM, Robinson S, Ukoumunne OC, Tydeman C. Promoting patient participation in consultations: a randomised controlled trial to evaluate the effectiveness of three patient-focused interventions. Patient Education and Counseling 2004;52:107-12.

Kim 2003 \{published and unpublished data\} Kim YM, Putjuk F, Basuki E, Kols A. Increasing patient participation in reproductive health consultations: an 
evaluation of 'Smart Patient' coaching in Indonesia. Patient Education and Counseling 2003;50:113-22.

\section{Lewis 1991 \{published data only\}}

Lewis CC, Pantell RH, Sharp L. Increasing patient knowledge, satisfaction and involvement: randomized trial of a communication intervention. Pediatrics 1991;88: 351-8.

Little 2004 \{published data only\}

Little P, Dorward M, Warner G, Moore M, Stephens K, Senior J, Kendrick T. Randomised controlled trial of effects of leaflets to empower patients in consultations in primary care. BMJ 2004;328:441-4.

Maly 1999 \{published and unpublished data\} Maly RC, Bourque LB, Engelhardt RF. A randomized controlled trial of facilitating information giving to patients with chronic medical conditions: effects on outcomes of care. Journal of Family Practice 1999;48:356-63.

Martinali 2001 \{published and unpublished data\} Martinali J, Bolman C, Brug J, van den Borne B, Bar F. A checklist to improve patient education in a cardiology outpatient setting. Patient Education and Counseling 2001; 42:231-8.

McCann 1996 \{published data only\}

McCann S, Weinman J. Encouraging patient participation in general practice consultations: effect on consultation length and content, patient satisfaction and health. Psychology and Health 1996;11:857-69.

* McCann S, Weinmann J. Empowering the patient in the consultation: a pilot study. Patient Education and Counseling 1996;27:227-34.

Middleton 2006 \{published and unpublished data\} Middleton JF, McKinley RK, Gillies CL. Effect of patient completed agenda forms and doctors' education about the agenda on the outcome of consultations: randomised controlled trial. BMJ 2006;332:1238-42.

Oliver 2001 \{published and unpublished data\} Oliver JW, Kravitz RL, Kaplan SH, Meyers FJ. Individualized patient education and coaching to improve pain control among cancer patients. Journal of Clinical Oncology 2001;19:2206-12.

Roter 1977 \{published data only\}

* Roter DL. Patient participation in the patient-provider interaction: the effects of patient question asking on the quality of interaction, satisfaction and compliance. Health Education Monographs 1977;5(4):281-315.

Roter DL. Patient question asking in physician-patient interaction. Health Psychology 1984;3(5):395-409.

Sander 1996a \{published and unpublished data\} Sander RW, Holloway RL, Eliason BC, Marbella AM, Murphy B, Yuen S. Patient-initiated prevention discussions: two interventions to stimulate patients to initiate prevention discussions. Journal of Family Practice 1996;43:468-74.

Sander 1996b \{published and unpublished data\} Sander RW, Holloway RL, Eliason BC, Marbella AM, Murphy B, Yuen S. Patient-initiated prevention discussions: two interventions to stimulate patients to initiate prevention discussions. Journal of Family Practice 1996;43:468-74.

Tabak 1988 \{published data only\}

Tabak ER. Encouraging patient question-asking: a clinical trial. Patient Education and Counseling 1988;12:37-49.

Tennstedt 2000 \{published and unpublished data\}

Tennstedt SL. Empowering older patients to communicate more effectively in the medical encounter. Clinics in Geriatric Medicine 2000;16:61-70.

Thompson 1990a \{published data only\}

Thompson SC, Nanni C, Schwankovsky L. Patient-oriented interventions to improve communication in a medical office visit. Health Psychology 1990;9:390-404.

Thompson 1990b \{published data only\}

Thompson SC, Nanni C, Schwankovsky L. Patient-oriented interventions to improve communication in a medical office visit. Health Psychology 1990;9:390-404.

Wilkinson 2002 \{published data only\}

Wilkinson CR, Williams M. Strengthening patient-provider relationships. Lippincott's Case Management 2002;7:86-102.

\section{References to studies excluded from this review}

Ader 1992 \{published data only\}

Ader DN, Seibring AR, Bhaskar P, Melamed BG.

Information seeking and interactive videodisc preparation for the third molar extraction. Journal of Oral and Maxillofacial Surgery 1992;50(1):27-31.

Agre 1993 \{published data only\}

Agre P. A trial of methods of instructing patients to meet informed consent guidelines for colonoscopy [EdD dissertation]. New York (NY): Columbia University Teachers College, 1993. [: CINAHL 1995025217]

Albertson 2002 \{published data only\}

Albertson G, Lin CT, Schilling L, Cyran E, Anderson S, Anderson RJ. Impact of a simple intervention to increase primary care provider recognition of patient referral concerns. American Journal of Managed Care 2002;8: 375-81.

Ambler 1999 \{published data only\}

Ambler N, Rumsey N, Harcourt D, Khan F, Cawthorn S, Barker J. Specialist nurse counsellor interventions at the time of diagnosis of breast cancer: comparing 'advocacy' with a conventional approach. Journal of Advanced Nursing 1999;29(2):445-53.

Anderson 1987 \{published data only\} Anderson LA, DeVellis BM, DeVellis RF. Effects of modelling on patient communication, satisfaction and knowledge. Medical Care 1987;25:1044-56.

Anderson 1995 \{published data only\} Anderson RM, Arnold MS, Funnell MM, Fitzgerald JT, Butler PM, Feste CC. Patient empowerment: results of a randomized controlled trial. Diabetes Care 1995;18:943-9.

Bekker 1999 \{published data only\} Bekker H, Thornton JG, Airey CM, Connelly JB, Hewison $\mathrm{J}$, Robinson $\mathrm{MB}$, et al.Informed decision making: an 
annotated bibliography and systematic review. Health

Technology Assessment 1999;3:1-150.

Belkora 2006 \{published data only\}

Belkora J, Katapodi M, Moore D, Franklin L, Hopper K, Esserman L. Evaluation of a visit preparation intervention implemented in two rural, underserved countries of Northern California. Patient Education and Counseling 2006;64(1-3):350-9.

Bergus 2002 \{published data only\}

Bergus GR, Levin IP, Elstein AS. Presenting risks and benefits to patients: the effects of information order on decision making. Journal of General Internal Medicine 2002; 17:612-7.

Bertakis 1977 \{published data only\} Bertakis KD. The communication of information from physician to patient:a method for increasing retention and satisfaction. Journal of Family Practice 1977;5:217-22.

Cegala 2001 \{published data only\} Cegala DJ, Post DM, McClure L. The effects of patient communication skills training on the discourse of older patients during a primary care interview. Journal of the American Geriatrics Society 2001;49:1505-11.

Courtney 1997 \{published data only\} Courtney MJ. The effect of a preanaesthetic information booklet on patient understanding and satisfaction. New Zealand Medical Journal 1997;110:212-4.

Cull 1998 \{published data only\}

Cull A, Miller H, Porterfield T, Mackay J, Anderson EDC, Steel CM, Elton RA. The use of videotaped information in cancer genetic counselling: a randomized evaluation study. British Journal of Cancer 1998;77:830-7.

Cunningham 2000 \{published data only\}

Cunningham C, Newton R. A question sheet to encourage written consultation questions. Quality in Health Care 2000;9:42-6.

Done 1998 \{published data only\}

Done ML, Lee A. The use of video to convey preanesthetic information to patients undergoing ambulatory surgery. Anesthesia and Analgesia 1998;87:531-6.

Dow 1991 \{published data only\}

Dow MG, Verdi MB, Sacco WP. Training psychiatric patients to discuss medication issues: effects on patient communication and knowledge of medications. Behavior Modification 1991;15:3-21.

Fleissig 2001 \{published data only\}

Fleissig A, Jenkins V, Fallowfield L. Results of an intervention study to improve communication about randomised clinical trials of cancer therapy. European Journal of Cancer 2001;37:322-31.

\section{Greaves 1999 \{published data only\}}

Greaves C. Patients informing patients: does information on video improve patient satisfaction and outcomes in day surgery?. National Research Register (http:// www.nrr.nhs.uk/ViewDocument.asp?ID=N0100043078) 1999 (accessed 30 April 2007). [: N0100043078]
Gustafson 1999 \{published data only\}

Gustafson DH, Hawkins R, Boberg E, Pingree S, Serlin RE, Graziano F, Chan CL. Impact of a patient-centered, computer-based health information/support system. American Journal of Preventive Medicine 1999;16:1-9.

Hardy 2001 \{published data only\}

Hardy KJ, O'Brien SV, Furlong NJ. Information given to patients before appointments and its effect on nonattendance rate. BMJ 2001;323:1298-1300.

Harmsen 2005 \{published data only\}

Harmsen H, Bernsen R, Meeuwesen L, Thomas S, Dorrenboom G, Pinto D, Bruijnzeels M. The effect of educational intervention on intercultural communication: results of a randomised controlled trial. British Journal of General Practice 2005;55:343-50.

Inui 1979 \{published data only\}

Inui TS, Jared RA, Carter WB, Plorde DS, Pecoraro RE, Chen MS, Dohan JJ. Effects of a self-administered health history on new-patient visits in a general medical clinic. Medical Care 1979;17:1221-8.

Jenkinson 1988 \{published data only\} Jenkinson D, Davison J, Jones S, Hawtin P. Comparison of effects of a self management booklet and audiocasette for patients with asthma. BMJ 1988;297:267-70.

Jensen 1993 \{published data only\}

Jensen AB, Madsen B, Andersen P, Rose C. Information for cancer patients entering a clinical trial: an evaluation of an information strategy. Eurpean Journal of Cancer 1993;29A: 2235-8.

Jones 2002 \{published data only\}

Jones R, Pearson J, McGregor S, Barrett A, Gilmour WH, Atkinson JM, et al.Does writing a list help cancer patients ask relevant questions?. Patient Education and Counseling 2002;47:369-71.

Kaplan 1989 \{published data only\} Kaplan SH, Greenfield S, Ware JE Jr. Assessing the effects of physician-patient interactions on the outcomes of chronic disease. Medical Care 1989;27(3 Suppl):S110-27.

Keeble 2002 \{published data only\}

Keeble W, Cobbe SM. Patient recall of medication details in the outpatient clinic. Audit and assessment of the value of printed instructions requesting patients to bring medications to clinic. Postgraduate Medical Journal 2002; 78:479-82.

Kennedy 2002 \{published data only\} Kennedy ADM, Sculpher MJ, Coulter A, Dwyer N, Rees M, Abrams KR, et al.Effects of decision aids for menorrhagia on treatment choices, health outcomes, and costs: a randomized controlled trial. JAMA 2002;288: 2701-8.

Kennedy 2002a \{published data only\} Kennedy AP, Rogers AE. Improving patient involvement in chronic disease management: the views of patients, GPs and specialists on a guidebook for ulcerative colitis. Patient Education and Counseling 2002;47:257-63. 
Kennedy 2004 \{published data only\}

Kennedy AP, Nelson E, Reeves D, Richardson G, Roberts C, Robinson A, et al.A randomised controlled trial to assess the effectiveness and cost of a patient orientated self management approach to chronic inflammatory bowel disease. Gut 2004;53:1639-45.

Kitai 2002 \{published data only\}

Kitai E, Vinker S, Kijner F, Lustman A. Erectile dysfunction - the effect of sending a questionnaire to patients on consultations with their doctor. Family Practice 2002;19: 247-50.

Kruijff 1997 \{published data only\}

Kruijff AF, van den Borne HW, Mesters I, Sterk PPH. [Ondersteuning van de voorlichting tijdens een medisch consult: een vragen-checklist voor astma- en COPD-patienten]. Tijdschrift voor Sociale Gezondheidszorg 1997;75:74-80.

\section{Kupst 1975 \{published data only\}}

Kupst MJ, Dresser K. Evaluation of methods to improve communication in the physician-patient relationship. Journal of Orthopaedics 1975;45:420-9.

\section{Kutner 1999 \{published and unpublished data\}} Kutner JS, Foehner K, Steiner JF. Evaluation of the impact of a pre-visit questionnaire for addressing cancer patients' information needs. Journal of Cancer Education 1999;14: 248-53.

Madden 1994 \{published data only\}

Madden S, Johnston M, Parbhoo S. Evaluation of women's worries and the effects of a preparatory booklet for patients attending a breast clinic. The Breast 1994;3:169-72.

McGee 1998 \{published data only\}

McGee DS, Cegala DJ. Patient communication skills training for improved communication competence in the primary care medical consultation. Journal of Applied Communication Research 1998;26:412-30.

Middleton 1995 \{published data only\}

Middleton JF. Asking patients to write lists: feasibility study. BMJ 1995;311:34.

Miller 1986 \{published data only\}

Miller G, Shank JC. Patient education: comparative effectiveness by means of presentation. Journal of Family Practice 1986;22:178-81.

\section{O’Mara 2003 \{published data only\}}

O'Mara L. Evidence based patient information leaflets in maternity care had limited visibility and did not promote informed choice of child bearing women. Evidence-based Nursing 2003;6:27.

Oermann 2003 \{published and unpublished data\} Oermann MH, Webb SA, Ashare JA. Outcomes of videotape instruction in clinic waiting area. Orthopaedic Nursing 2003;22:102-5.

Pasacreta 1998 \{published data only\} Pasacreta JV. An empowerment information intervention improved participation in treatment decision making in men with recently diagnosed prostate cancer - commentary. Evidence-based Nursing 1998;1:49.

Post 2002 \{published data only\}

Post DM, Cegala DJ, Marinelli TM. The other half of the whole: teaching patients to communicate with physicians.

Family Medicine 2002;34:344-52.

Pruyn 2004 \{published data only\}

Pruyn JFA, Heule-Dieleman HAG, Knegt PP, Mosterd FR, van Hest MAG, Sinnige HAM, et al.On the enhancement of efficiency in care for cancer patients in outpatient clinics: an instrument to accelerate psychosocial screening and referral. Patient Education and Counseling 2004;53:135-40.

Richard 1998 \{published data only\}

Richard D. Information leaflet for lower respiratory tract illness. Journal of Family Practice 1998;46:197-8.

Rieger 1999 \{published data only\}

Rieger N, Kennedy R, Farrell S, Woods R. Informed consent, patient satisfaction and length of hospitalisation: the contribution of written information leaflets. Health Promotion Journal of Australia 1999;9:188-191.

Robinson 1985 \{published data only\}

Robinson EJ, Whitfield MJ. Improving the efficiency of patients' comprehension monitoring: a way of increasing patients' participation in general practice consultations. Social Science and Medicine 1985;21:915-9.

Rost 1991 \{published data only\} Rost KM, Flavin KS, Cole K, McGill JB. Change in metabolic control and functional status after hospitalization: impact of patient activation intervention in diabetic patients. Diabetes Care 1991;14:881-9.

Ruland 2003 \{published data only\}

Ruland CM, White T, Stevens M, Fanciullo G, Khilani SM. Effects of a computerized system to support shared decision making in symptom management of cancer patients: preliminary results. Journal of the American Medical Informatics Association 2003;10:573-9.

Rutten 1991 \{published data only\}

Rutten G, van Eijk J, Beek M, van der Velden H. Patient education about cough: effect on the consulting behaviour of general practice patients. British Journal of General Practice 1991;41:289-92.

Rutten 1993 \{published data only\} Rutten GEHM, Beek MML, van Eijk JTM. Effects of systematic patient education about cough on the consulting behaviour of a general practice population. Patient Education and Counseling 1993;22:127-32.

Schouten 2005 \{published data only\} Schouten BC, Meeuwesen L, Harmsen HAM. The impact of an intervention in intercultural communication on doctor-patient interaction in The Netherlands. Patient Education and Counseling 2005;58:288-95.

Selvachandran 2002 \{published data only\} Selvachandran SN, Hodder RJ, Ballal MS, Jones P, Cade D. Prediction of colorectal cancer by a patient consultation 
questionnaire and scoring system: a prospective study. Lancet 2002;36:278-83.

Sepuchra 2000 \{published data only\}

Sepuchra KR, Belkora JK, Tripathy D, Esserman LJ. Building bridges between physicians and patients: results of a pilot study examining new tools for collaborative decision making in breast cancer. Journal of Clinical Oncology 2000; 18:1230-8.

Sepuchra 2002 \{published data only\}

Sepuchra KR, Belkora JK, Mutchnick S, Esserman LJ.

Consultation planning to help breast cancer patients prepare for medical consultations: effect on communication and satisfaction for patients and physicians. Journal of Clinical Oncology 2002;20:2695-2700.

Sepuchra 2003 \{published data only\}

Sepuchra KR, Belkora JK, Aviv C, Mutchnick S, Esserman LJ. Improving the quality of decision making in breast cancer: consultation planning template and consultation recording template. Oncology Nursing Forum 2003;30: 99-106.

Shepperd 1995 \{published data only\}

Shepperd S, Coulter A, Farmer A. Using interactive videos in general practice to inform patients about treatment choices: a pilot study. Family Practice 1995;12:443-7.

Smith 1998 \{published data only\}

Smith P. The role of the general health questionnaire in general practice consultations. British Journal of General Practice 1998;48:1565-9.

Stapleton 2002 \{published data only\} Stapleton H, Kirkham M, Thomas G. Qualitative study of evidence based leaflets in maternity care. $B M J$ 2002;324: 639-43.

Street 1995 \{published data only\}

Street RL, Voigt B, Geyer C, Manning T, Swanson GP. Increasing patient involvement in choosing treatment for early breast cancer. Cancer 1995;76:2275-85.

Sulmasy 1996 \{published data only\} Sulmasy DP, Song KY, Marx ES, Mitchell JM. Strategies to promote the use of advanced directives in a residency outpatient practice. Journal of General Internal Medicine 1996;11:657-63.

Teutsch 2003 \{published data only\}

Teutsch C. Patient-doctor communication. Medical Clinics of North America 2003;87(5):1115-45.

Thomas 2000 \{published data only\}

Thomas R, Daly M, Perryman B, Stockton D. Forewarned is forearmed - benefits of preparatory information on video cassette for patients receiving chemotherapy or radiotherapy - a randomised controlled trial. European Journal of Cancer 2000;36:1536-43.

Tran 2004 \{published data only\}

Tran AN, Haidet P, Street RL, O'Malley KJ, Martin F, Ashton CM. Empowering communication: a communitybased intervention for patients. Patient Education and Counseling 2004;52:113-21.
Van Dam 2003 \{published data only\}

van Dam HA, van der Horst F, van den Borne B, Ryckman $\mathrm{R}$, Crebolder H. Provider-patient interaction in diabetes care: effects on patient self-care and outcomes. A systematic review. Patient Education and Counseling 2003;51:17-28.

\section{Velikova 2002 \{published data only\}}

Velikova G, Brown JM, Smith AB, Selby PJ. Computerbased quality of life questionniares may contribute to doctor-patient interactions in oncology. British Journal of Cancer 2002;86:51-9.

Wallston 1979 \{published data only\} Wallston BS, Wallston KA, DeVellis BM, McLendon E, Percy J. Modification of question asking behavior in high and low assertive women through modeling and specific instructions. Social Behavior and Personality 1979;6: 195-204.

Weinberger 1998 \{published data only\} Weinberger M. Telephone-based interventions in outpatient care. Annals of Rheumatic Diseases 1998;57:196-7.

Wells 2004 \{published data only\} Wells T, Falk S, Dieppe P. The patients' written word: a simple communication aid. Patient Education and Counseling 2004;54:197-200.

Wetzels 2005 \{published data only\} Wetzels R, Wensing M, van Weel C, Grol R. A consultation leaflet to improve an older patient's involvement in general practice care: a randomized trial. Health Expectations 2005; 8:286-94.

Wilson 2002 \{published data only\}

Wilson AS, Kitas GD, Carruthers DM, Reay C, Skan J, Harris $S$, et al.Computerized information-gathering in specialist rheumatology clinics: an initial evaluation of an electronic version of the Short Form 36. Rheumatology 2002;41:268-73.

\section{Additional references}

\section{Anderson 1991}

Anderson LA, Sharpe PA. Improving patient and provider communication: a synthesis and review of communication interventions. Patient Education and Counseling 1991;17: 99-134.

Beisecker 1990

Beisecker AE, Beisecker TD. Patient information-seeking behaviours when communicating with doctors. Medical Care 1990;28(1):19-28.

\section{Bensing 2000}

Bensing JM, Verhaak PFM, van Dulmen AM, Visser AP. Communication: the royal pathway to patient-centered medicine. Patient Education and Counseling 2000;39:1-3.

Boberg 2003

Boberg EW, Gustafson DH, Hawkins RP, Offord KP, Koch C, Wen KY, et al.Assessing the unmet information, supoort and care delivery needs of men with prostate cancer. Patient Education and Counseling 2003;49(3):233-42. 


\section{Boreham 1978}

Boreham P, Gibson D. The informative process in private medical consultations: a preliminary investigation. Social Science and Medicine 1978;12(5A):409-16.

\section{Cegala 2003}

Cegala DJ. Patient communication skills training: a review with implications for cancer patients. Patient Education and Counseling 2003;50:91-4.

Clarke 2003

Clarke M, Oxman AD, editors. Cochrane Reviewers' Handbook 4.2.0 [updated March 2003]. In: The Cochrane Library, Issue 2, 2003. Oxford: Update Software. Updated quarterly.

\section{Cohen 1988}

Cohen J. Statistical power analysis for the behavioural sciences. Statistical power analysis for the behavioural sciences. Hillsdale, New Jersey: Lawrence Erlbaum Associates, 1988.

\section{Deyo 1986}

Deyo RA, Diehl AK. Patient satisfaction with medical care for low back pain. Spine 1986;11(1):28-30.

\section{Edwards 2006}

Edwards A, Elwyn G. Inside the black box of shared decision making - distinguishing between the process of involvement and who makes the decision. Health Expectations 2006;9: 307-20.

Egbert 1964

Egbert LD, Batitt GE, Welch CE. Reduction of postoperative pain by encouragement and instruction of patients. New England Journal of Medicine 1964;270: $825-7$.

\section{Elwyn 1999}

Elwyn G, Edwards A, Kinnersley P. Shared decision making in primary care: the neglected second half of the consultation. British Journal of General Practice 1999;49: 477-82.

\section{Elwyn 2000}

Elwyn G, Edwards A, Kinnersley P, Grol R. Shared decision making and the concept of equipoise: the competences of involving patients in healthcare choices. British Journal of General Practice 2000;50:892-7.

\section{Faden 1981}

Faden RR, Becker C, Lewis C, Freeman J, Faden AI. Disclosure of information to patients in medical care. Medical Care 1981;19:718-33.

\section{Fallowfield 1994}

Fallowfield LJ, Hall A, Maguire P, Baum M, A'Hern RP. Psychological effects of being offered choice of surgery for breast cancer. BMJ 1994;309(6952):448.

\section{Fallowfield 1999}

Fallowfield L, Jenkins V. Effective communication skills are the key to good cancer care. European Journal of Cancer 1999;35(11):1592-7.

\section{Fallowfield 2002}

Fallowfield L, Jenkins V, Farewell V, Saul J, Duffy A, Eves R. Efficacy of a Cancer Research UK communication skills training model for oncologists: a randomised controlled trial. Lancet 2002;359(9307):650-6.

\section{Fleissig 2000}

Fleissig A. Patients are frightened and their information needs fluctuate. BMJ 2000;321(7261):632.

\section{Gaston 2005}

Gaston CM, Mitchell G. Information giving and decisionmaking in patients with advanced cancer: A systematic review. Social Science and Medicine 2005;61:2252-64.

\section{Hall 1988}

Hall JA, Roter DL, Katz NR. Meta-analysis of correlates of provider behavior in medical encounters. Medical Care 1988;26(7):657-75.

\section{Harrington 2004}

Harrington J, Noble LM, Newman SP. Improving patients' communication with doctors: a systematic review of intervention studies. Patient Education and Counseling 2004;52:7-16.

\section{Helman 2007}

Helman, C. Culture, health and illness. London: Hodder Arnold, 2007.

\section{Higgins 2006}

Higgins JPT, Green S (editors). Cochrane handbook for systematic reviews of interventions 4.2.6 [Updated September 2006]. The Cochrane Library. Chichester, UK: John Wiley and Sons, Ltd, 2006.

\section{Jahad 1995}

Jahad AR. Asking patient to write lists. BMJ 1995;311:746

\section{Jefford 2002}

Jefford M, Tattersall MH. Informing and involving cancer patients in their own care. Lancet Oncology 2002;3(10): 629-37.

\section{Jenkins 2001}

Jenkins V, Fallowfield L, Saul J. Information needs of patients with cancer: results from a large study in UK cancer centres. British Journal of Cancer 2001;84(1):48-51.

\section{Jenkins 2002}

Jenkins V, Fallowfield L. Can communication skills training alter physicians' beliefs and behavior in clinics?. Journal of Clinical Oncology 2002;20(3):765-9.

\section{Kindelan 1987}

Kindelan K, Kent G. Concordance between patients' information preferences and general practitioners' perceptions. Psychology and Health 1987;1:399-409.

\section{Kinnersley 1999}

Kinnersley P, Stott N, Peters TJ, Harvey I. The patientcentredness of consultations and outcome in primary care. British Journal of General Practice 1999;49:711-6.

\section{Korsch 1968}

Korsch BM, Gozzi EK, Francis V. Gaps in doctor-patient communication. Pediatrics 1968;42(5):855-71.

\section{Kramer 2004}

Kramer AWM, Dusman H, Tan LHC, Jansen JJM, Grol RPTM, van der Vleuten CPM. Acquisition of 
communication skills in postgraduate training for general practice. Medical Education 2004;38:158-67.

\section{Krupat 2000}

Krupat E, Rosenkranz SL, Yeager CM, Barnard K, Putnam SM, Inui TS. The practice orientations of physicians and patients: the effect of doctor-patient congruence on satisfaction. Patient Education and Counseling 2000;39 49-59.

\section{Lewin 2001}

Lewin SA, Skea ZC, Entwistle V, Zwarenstein M, Dick J. Interventions for providers to promote a patient-centred approach in clinical consultations (Cochrane Review). Cochrane Database of Systematic Reviews 2001, Issue 4. [DOI: 10.1002/14651858.CD003267]

\section{Leydon 2000}

Leydon GM, Boulton M, Moynihan C, Jones A, Mossman J, Boudioni M, McPherson K. Cancer patients' information needs and information seeking behaviour: in depth interview study. BMJ 2000;320(7239):909-13.

\section{Maguire 1986}

Maguire P, Fairbairn S, Fletcher C. Consultation skills of young doctors. 1. Benefits of feedback training in interviewing as students persist. British Medical Journal Clinical Research Edition 1986;292(6535):1573-6.

\section{Maguire 1996}

Maguire P, Booth K, Elliott C, Jones B. Helping health professionals involved in cancer care acquire key interviewing skills - the impact of workshops. European Journal of Cancer 1996;32A(9):1486-8.

\section{Makoul 1995}

Makoul G, Arnston P, Schofield T. Health promotion in primary care: physician-patient communication and decision making about prescription medications. Social Science and Medicine 1995;41(9):1241-54.

\section{McKenzie 2000}

McKenzie J. Information needs of patients with cancer: similar study had similar findings. BMJ 2000;321(7261): 632.

\section{Meredith 1996}

Meredith C, Symonds P, Webster L, Lamont D, Pyper E, Gillis CR, Fallowfield L. Information needs of cancer patients in west Scotland: cross sectional survey of patients' views. BMJ 1996;313(7059):724-6.

\section{Neighbour 1996}

Neighbour R. The Inner Consultation. Newbury: Petroc Press, 1996.

\section{Rogers 2005}

Rogers A, Kennedy A, Nelson E, Robinson A. Uncovering the limits of patient-centeredness: implementing a self management trial for chronic illness. Qualitative Health Research 2005;15:224-39.

\section{Roter 1995}

Roter DL, Hall JA, Kern De, Barker LR, Cole KA, Roca RP. Improving physicians' interviewing skills and reducing patients' emotional distress: a randomized controlled trial. Archives of Internal Medicine 1995;155:1877-84.

\section{Roter 2000}

Roter D. The enduring and evolving nature of the patientphysician relationship. Patient Education and Counseling 2000;39:5-15.

\section{Scott 2003}

Scott JT, Harmsen M, Prictor MJ, Entwistle VA, Sowden AJ, Watt I. Recordings or summaries of consultations for people with cancer. Cochrane Database of Systematic Reviews 2003, Issue 4.[Art. No.: CD001539. DOI: 10.1002/ 14651858.CD001539.pub2]

\section{Silverman 2005}

Silverman J, Kurtz S, Draper J. Skills for communicating with patients. Skills for communicating with patients. Abingdon: Radcliffe Medical Press, 2005.

\section{Starfield 1981}

Starfield B, Wray C, Hess K, Gross R, Birk PS, D’Lugoff $\mathrm{BC}$. The influence of patient-practitioner agreement on outcome of care. American Journal of Public Health 1981; 71:127-31.

\section{Stewart 1995}

Stewart MA. Effective physician-patient communication and health outcomes: a review. Canadian Medical Association Journal 1995;152(9):1423-33.

\section{Stimson 1975}

Stimson GV, Webb B. Going to see the doctor: the consultation process in general practice. London: Routledge and Kegan Paul, 1975.

\section{Svarstad 1974}

Svarstad BL. The doctor-patient encounter: an observational study of communication and outcome. The doctor-patient encounter: an observational study of communication and outcome. Doctoral dissertation. University of Wisconsin, 1974.

\section{Tuckett 1985}

Tuckett D, Boulton M, Olson I, Williams A. Meetings between experts: an approach to sharing ideas in medical consultations. Meetings between experts: an approach to sharing ideas in medical consultations. London: Tavistock Publications, 1985.

\section{Waitzkin 1984}

Waitzkin H. Doctor-patient communciation: clinical implications of social scientific research. JAMA 1984;252 (17):2441-6.

\section{Wetzels 2007}

Wetzels R, Harmsen M, Van Weel C, Grol R, Wensing M. Interventions for improving older patients' involvement in primary care episodes. Cochrane Database of Systematic Reviews 2007, Issue 1. [DOI: 10.1002/ 14651858.CD004273.pub2]

\section{Wilson 2002a}

Wilson A, Childs S. The relationship between consultation length, process and outcomes in general practice: a 
systematic review. British Journal of General Practice 2002;

52:1012-1020.

* Indicates the major publication for the study

Copyright (@) 2009 The Cochrane Collaboration. Published by John Wiley \& Sons, Ltd. 
CHARACTERISTICS OF STUDIES

Characteristics of included studies [ordered by study ID]

Bolman 2005

\begin{tabular}{ll} 
Methods & $\begin{array}{l}\text { RCT } \\
\text { Randomisation such that each clinician got balanced number of intervention and control patients }\end{array}$ \\
\hline Participants & $\begin{array}{l}\text { Setting: One cardiology clinic, the Netherlands. } \\
\text { Clinicians : } 16 \text { cardiologists. } \\
\text { Participants: Adult patients recently discharged after acute cardiac event attending for three follow up } \\
\text { consultations; } 194 \text { patients approached; } 153 \text { recruited and randomised; } 118 \text { at baseline (2 died, } 33 \text { with- } \\
\text { drew); } 105 \text { in intention-to-treat analysis (13 excluded); } 75 \text { completed follow up }\end{array}$ \\
\hline Interventions & $\begin{array}{l}\text { Timing: One week before consultation. } \\
\text { Intervention: Question prompt sheet - containing } 49 \text { frequently asked questions. Patients encouraged to } \\
\text { identify which questions applied to them and ask these in consultation. Intervention repeated after each } \\
\text { consultation } \\
\text { Controls: Information booklet providing details of telephone helpline ('did not contain substantive infor- } \\
\text { mation about coronary artery disease') } \\
\text { Clinicians: Brief training on how to respond to patients' questions }\end{array}$ \\
\hline
\end{tabular}

\begin{tabular}{l|l} 
Outcomes & Pre consultation questionnaire: \\
& State anxiety (20 item Spielberger) \\
& Exit questionnaire: \\
& Participation $(2$ items) \\
& Satisfaction $(18$ items) \\
& Information exchange (10 items) \\
& Knowledge (25 items) \\
& Clinician questionnaire: length of consultation (estimate) \\
\hline Notes & \\
\hline
\end{tabular}

\section{Risk of bias}

\begin{tabular}{l|ll}
\hline Item & Authors' judgement & Description \\
\hline Allocation concealment? & Unclear & B - Unclear \\
\hline
\end{tabular}

Brown 1999

\begin{tabular}{ll}
\hline Methods & $\begin{array}{l}\text { RCT } \\
\text { Two intervention groups and one control group; one third of patients allocated to each group }\end{array}$ \\
\hline Participants & $\begin{array}{l}\text { Setting: One cancer clinic, Australia. } \\
\text { Clinicians: Two oncologists. } \\
\text { Participants: Adult patients with mixed cancers; } 61 \text { approached, } 60 \text { randomised (1 refused); } 60 \text { completed } \\
\text { follow up }\end{array}$
\end{tabular}


Brown 1999 (Continued)

$\begin{array}{ll}\text { Interventions } & \text { Timing: Immediately before consultation. } \\ \text { Interventions: a) Question prompt sheet - containing } 17 \text { frequently asked questions. Doctors endorsed the } \\ \text { prompt sheet and went through list eliciting and answering questions according to a standard protocol; } \\ \text { b) question prompt sheet/coaching - sheet and coaching from research psychologist covering question } \\ \text { generation, benefits of and barriers to question asking and rehearsal } \\ \text { Controls: Usual care. } \\ \text { Clinicians: Training to endorse the interventions. }\end{array}$

Risk of bias

\begin{tabular}{l|ll}
\hline Item & Authors' judgement & Description \\
\hline Allocation concealment? & Unclear & B - Unclear \\
\hline
\end{tabular}

Brown 2001

\begin{tabular}{ll}
\hline Methods & $\begin{array}{l}\text { RCT } \\
\text { Two intervention groups and one control group; one quarter of patients to each intervention group and } \\
\text { one half to control group } \\
\text { Clinicians randomised to be 'active' or 'passive'. }\end{array}$ \\
\hline Participants & $\begin{array}{l}\text { Setting: Two cancer clinics, Australia. } \\
\text { Clinicians: } 9 \text { oncologists. } \\
\text { Participants: Adult patients with mixed cancers; } 336 \text { approached, } 318 \text { randomised (18 refused) and } \\
\text { completed follow up }\end{array}$ \\
\hline Interventions & $\begin{array}{l}\text { Timing: Immediately before consultation. } \\
\text { Intervention: Question prompt sheet endorsing question asking as an activity useful to the patient and } \\
\text { welcomed by the doctor. Participants circled questions they would ask. } \\
\text { Half those who got prompt sheets saw doctor who actively endorsed sheet and systematically reviewed } \\
\text { each question } \\
\text { Controls: Usual care. } \\
\text { Clinicians: Half trained to review question sheet and monitored }\end{array}$ \\
\hline Outcomes & $\begin{array}{l}\text { Consultation audiotape: } \\
\text { Question asking } \\
\text { Consultation length }\end{array}$
\end{tabular}


Brown 2001 (Continued)

Exit questionnaire:

State anxiety (Spielberger - no of items not provided)

Postal questionnaire (7 days after consultation):

Information needs ( 7 content areas)

Satisfaction (25 items)

Telephone interview (7 to 10 days after consultation):

Recall

Notes

Risk of bias

\begin{tabular}{l|ll}
\hline Item & Authors' judgement & Description \\
\hline Allocation concealment? & Unclear & B - Unclear \\
\hline
\end{tabular}

Bruera 2003

\begin{tabular}{|c|c|c|}
\hline Methods & \multicolumn{2}{|l|}{ RCT } \\
\hline Participants & \multicolumn{2}{|c|}{$\begin{array}{l}\text { Setting: One cancer clinic, USA. } \\
\text { Clinicians: number not stated. } \\
\text { Participants: Adult women with breast cancer; } 132 \text { screened for entry, } 60 \text { enrolled and randomised, } 60 \\
\text { completed follow up }\end{array}$} \\
\hline Interventions & \multicolumn{2}{|c|}{$\begin{array}{l}\text { Timing: Immediately before consultation. } \\
\text { Intervention: Question prompt sheet - containing } 22 \text { frequently asked questions with space for patient to } \\
\text { write additional questions } \\
\text { Controls: General information sheet about breast cancer } \\
\text { Clinicians: Usual practice. }\end{array}$} \\
\hline Outcomes & \multicolumn{2}{|c|}{$\begin{array}{l}\text { Consultation audiotape: } \\
\text { Question asking } \\
\text { Consultation length } \\
\text { Exit questionnaire: } \\
\text { Satisfaction (6 items) } \\
\text { Clinician questionnaire: } \\
\text { Satisfaction ( } 1 \text { item) } \\
\text { Estimate of consultation length. }\end{array}$} \\
\hline \multicolumn{3}{|l|}{ Notes } \\
\hline \multicolumn{3}{|l|}{ Risk of bias } \\
\hline Item & Authors' judgement & Description \\
\hline Allocation concealment? & Unclear & B - Unclear \\
\hline
\end{tabular}


Butow 1994

\begin{tabular}{ll}
\hline Methods & RCT \\
\hline Participants & $\begin{array}{l}\text { Setting: One cancer clinic, Australia. } \\
\text { Clinician: One oncologist. } \\
\text { Patients: Adults with mixed cancers; } 142 \text { recruited and randomised, } 92 \text { completed follow up }\end{array}$ \\
\hline Interventions & $\begin{array}{l}\text { Timing: Immediately before consultation. } \\
\text { Intervention: Question prompt sheet - designed to encourage patients to ask questions in the consultation. } \\
\text { Patients instructed to list and rank questions to ask } \\
\text { Controls: General information sheet about cancer services. } \\
\text { Clinicians: Usual practice. }\end{array}$ \\
\hline Outcomes & $\begin{array}{l}\text { Consultation audiotape: } \\
\text { Question asking } \\
\text { Consultation length } \\
\text { Postal questionnaire (1 to } 3 \text { weeks after consultation): } \\
\text { Satisfaction (22 items) } \\
\text { Psychological adjustment (21 item) } \\
\text { Recall of information }\end{array}$ \\
\hline Allocation concealment? & Unclear \\
\hline Notes & \begin{tabular}{l} 
Authors' judgement Description \\
\hline bias
\end{tabular} \\
\hline
\end{tabular}

Butow 2004

\begin{tabular}{ll}
\hline Methods & RCT \\
\hline Participants & $\begin{array}{l}\text { Setting: One cancer clinic, Australia. } \\
\text { Clinicians: Four oncologists. } \\
\text { Patients: Adults with mixed cancers; } 200 \text { recruited and randomised, } 141 \text { completed follow up }\end{array}$ \\
\hline Interventions & $\begin{array}{l}\text { Timing: at least } 2 \text { days before consultation. } \\
\text { Intervention: Question prompt sheet - designed to encourage patients to ask questions in the consultation } \\
\text { Controls: General information sheet about cancer services. } \\
\text { Clinicians: Usual practice. }\end{array}$ \\
\hline Outcomes & $\begin{array}{l}\text { Pre consultation questionnaire: } \\
\text { Anxiety (Spielberger } 20 \text { items) } \\
\text { Depression (no of items not provided) } \\
\text { Information and involvement preferences (2 items) } \\
\text { Satisfaction with intervention (no of items not provided) } \\
\text { Consultation audiotape: } \\
\text { Question asking } \\
\text { Consultation length }\end{array}$ \\
\hline
\end{tabular}


Butow 2004 (Continued)

Patient participation

Exit questionnaire:

Anxiety (Spielberger 20 items)

Depression (no of items not provided)

Perception of involvement (no of items not provided)

Satisfaction with treatment decision (no of items not provided)

Satisfaction with consultation (25 items)

Postal questionnaire (1 month after consultation):

Anxiety (Spielberger 20 items)

Depression (no of items not provided)

Perception of involvement (no of items not provided)

Satisfaction with treatment decision (no of items not provided)

Satisfaction with consultation (25 items)

Clinician questionnaire: Satisfaction with decision making, perceived success in meeting patient's information preferences (no of items not provided)

Notes

Risk of bias

\begin{tabular}{lll}
\hline Item & Authors' judgement & Description \\
\hline Allocation concealment? & Unclear & B - Unclear \\
\hline
\end{tabular}

\section{Cegala 2000}

\begin{tabular}{ll} 
Methods & RCT \\
& $\begin{array}{l}\text { Two intervention and one control group. } \\
\text { Six patients per physician entered into study, two to each group }\end{array}$ \\
\hline Participants & $\begin{array}{l}\text { Setting: Two university hospital clinics and } 7 \text { private practices, USA } \\
\text { Clinicians: } 25 \text { family physicians. } \\
\text { Participants: Adults with mixed problems; } 150 \text { recruited and randomised, } 134 \text { completed follow up }\end{array}$ \\
\hline
\end{tabular}

Interventions

Timing: Intervention a) 2 to 4 days before consultation; Intervention b) immediately before consultation Interventions: a) booklet : 14 page workbook encouraging patient to list topics they wanted to discuss then sections on information seeking and verifying. Booklet briefly gone over on arrival. b) brief advice: summary of points in booklet, patients encouraged to organise thoughts and ask questions

Controls: Usual care.

Clinicians: Usual practice.

$\begin{array}{ll}\text { Outcomes } & \text { Consultation audiotape: } \\ \text { Question asking } \\ \text { Information provision by doctor } \\ \text { Information provision by patient } \\ \text { Verifying of information by patient } \\ \text { Telephone interview (2 weeks after consultation): } \\ \text { Compliance }\end{array}$


Cegala 2000 (Continued)

Notes

Risk of bias

\begin{tabular}{l|ll}
\hline Item & Authors' judgement & Description \\
\hline Allocation concealment? & Unclear & B - Unclear \\
\hline
\end{tabular}

Davison 1997

\begin{tabular}{ll}
\hline Methods & RCT \\
\hline Participants & $\begin{array}{l}\text { Setting: One community clinic, Canada. } \\
\text { Clinicians: Two urologists. } \\
\text { Participants: Men with prostate cancer; } 60 \text { approached and randomised, } 59 \text { completed follow up }\end{array}$ \\
\hline Interventions & $\begin{array}{l}\text { Timing: Immediately before consultation. } \\
\text { Intervention: Coaching - patients asked by researcher to think about the type of information they needed } \\
\text { to decide treatment best for them. List of frequently asked questions reviewed and questions identified. } \\
\text { Given information pack and shown where to find answers to questions. Further questions added to list. } \\
\text { Encouraged to ask for audiotape of consultation } \\
\text { Controls: Information package which they were encouraged to read and 'social' interview } \\
\text { Clinicians: Usual practice. }\end{array}$ \\
\hline Outcomes & $\begin{array}{l}\text { Phone interview }(5 \text { to } 6 \text { weeks after consultation): } \\
\text { State anxiety (Spielberger } 20 \text { items) } \\
\text { Trait anxiety (Spielberger } 20 \text { items) } \\
\text { Depression (20 items) } \\
\text { Preferences for control over treatment decision (5 items) }\end{array}$ \\
\hline Notes & \begin{tabular}{l} 
\\
\hline
\end{tabular} \\
\hline
\end{tabular}

\section{Risk of bias}

\begin{tabular}{|c|c|c|}
\hline Item & Authors' judgement & Description \\
\hline Allocation concealment? & Unclear & B - Unclear \\
\hline
\end{tabular}

Davison 2002

\begin{tabular}{ll}
\hline Methods & RCT \\
\hline Participants & $\begin{array}{l}\text { Setting: Three cancer clinics, Canada. } \\
\text { Clinicians: Number not stated. } \\
\text { Participants: Women with breast cancer; } 749 \text { recruited and randomised, } 734 \text { completed follow up }\end{array}$
\end{tabular}


Davison 2002 (Continued)

\begin{tabular}{|c|c|}
\hline Interventions & $\begin{array}{l}\text { Timing: Immediately before consultation. } \\
\text { Intervention: Computer programme/coaching - patients used computer programme to identify control } \\
\text { preferences then completed questionnaire on computer to identify information needs. Nurse then coached } \\
\text { patient in using computer print outs in the consultation to gather information } \\
\text { Controls: Completed paper version of control preferences scale and had general discussion with nurse } \\
\text { Clinicians: Usual practice. }\end{array}$ \\
\hline Outcomes & $\begin{array}{l}\text { Pre consultation questionnaire: } \\
\text { Role preferences (Active, Collaborative, Passive) } \\
\text { Exit questionnaire: } \\
\text { Satisfaction (14 items) } \\
\text { Role assumed } \\
\text { Role preferred }\end{array}$ \\
\hline Notes & \\
\hline
\end{tabular}

\section{Risk of bias}

\begin{tabular}{|c|c|c|}
\hline Item & Authors' judgement & Description \\
\hline Allocation concealment? & Unclear & B - Unclear \\
\hline
\end{tabular}

Finney 1990

\begin{tabular}{ll}
\hline Methods & RCT \\
\hline Participants & $\begin{array}{l}\text { Setting: One well baby clinic, USA. } \\
\text { Clinicians: One male paediatrician and one female paediatric nurse practitioner (most patients in each } \\
\text { group saw the nurse practitioner) } \\
\text { Participants: Mothers and their babies consulting for well baby checks; } 32 \text { recruited, randomised and } \\
\text { completed follow up }\end{array}$ \\
\hline Interventions & $\begin{array}{l}\text { Timing: Immediately before consultation. } \\
\text { Intervention: Coaching - brief prompting strategy to ask questions of interest to mothers } \\
\text { Controls: General talk with investigator of equivalent length (no further details provided) } \\
\text { Clinicians: Usual practice. }\end{array}$ \\
\hline Outcomes & $\begin{array}{l}\text { Consultation audiotape: } \\
\text { Question asking } \\
\text { Bids for information } \\
\text { Parent initiated discussions } \\
\text { Total topics discussed } \\
\text { Asking and discussion of initial questions } \\
\text { Exit questionnaire: } \\
\text { Satisfaction (16 items) }\end{array}$ \\
\hline
\end{tabular}

Notes 
Finney 1990 (Continued)

\begin{tabular}{lll} 
Risk of bias & & \\
\hline Item & Authors' judgement & Description \\
\hline Allocation concealment? & Unclear & B - Unclear \\
\hline
\end{tabular}

\section{Fleissig 1999}

\begin{tabular}{|c|c|c|}
\hline Methods & \multicolumn{2}{|l|}{ RCT } \\
\hline Participants & \multicolumn{2}{|c|}{$\begin{array}{l}\text { Setting: Three outpatient clinics (Gynaecology, Orthopaedics and Dermatology) at one hospital, UK } \\
\text { Clinicians: Number not stated. } \\
\text { Participants: Newly referred adult patients; } 2603 \text { approached, } 1683 \text { attended clinic during study period, } \\
1208 \text { randomised, } 762 \text { completed follow up }\end{array}$} \\
\hline Interventions & \multicolumn{2}{|c|}{$\begin{array}{l}\text { Timing: Posted to patients two weeks before consultation. } \\
\text { Intervention: Question prompt sheet - 'Help card' suggesting general questions to ask clinician with space } \\
\text { for patient to write down further questions. Suggestions covered patient's condition, tests, treatments and } \\
\text { other concerns } \\
\text { Controls: Usual care. } \\
\text { Clinicians: Usual practice. }\end{array}$} \\
\hline Outcomes & \multicolumn{2}{|c|}{$\begin{array}{l}\text { Postal questionnaire (within } 1 \text { week of consultation): } \\
\text { Satisfaction ( } 9 \text { items) } \\
\text { Information needs } \\
\text { Expectation that questions welcome } \\
\text { Preparation of questions } \\
\text { Were prepared questions raised? } \\
\text { Unanswered questions after consultation }\end{array}$} \\
\hline \multicolumn{3}{|l|}{ Notes } \\
\hline \multicolumn{3}{|l|}{ Risk of bias } \\
\hline Item & Authors' judgement & Description \\
\hline Allocation concealment? & Unclear & B - Unclear \\
\hline
\end{tabular}

\section{Ford 1995}

\begin{tabular}{ll}
\hline Methods & RCT \\
\hline Participants & $\begin{array}{l}\text { Setting: One cancer clinic, UK. } \\
\text { Clinicians: } 5 \text { oncologists. } \\
\text { Participants: newly referred patients with mixed cancers; } 117 \text { recruited and randomised, } 95 \text { consulted }\end{array}$
\end{tabular}


Ford 1995 (Continued)

\begin{tabular}{l|l}
\hline Interventions & $\begin{array}{l}\text { Timing: Prior to consultation. } \\
\text { Intervention: Audiotape of previous consultation, patients encouraged to listen and identify further ques- } \\
\text { tions } \\
\text { Controls: Usual care. } \\
\text { Clinicians: Usual practice. }\end{array}$ \\
\hline Outcomes & $\begin{array}{l}\text { Pre-consultation questionnaire: } \\
\text { Psychological morbidity } \\
\text { Depression (GHQ 30 items) } \\
\text { Anxiety (HADS 14 items) } \\
\text { Consultation audiotape: } \\
\text { Consultation length } \\
\text { Question asking } \\
\text { Requests for clarification } \\
\text { Requests for information given earlier } \\
\text { Patient: clinician talk }\end{array}$ \\
\hline Notes & \begin{tabular}{l} 
Authors' judgement Description \\
\hline Risk of bias
\end{tabular} \\
\hline Allocation concealment? & Yes \\
\hline
\end{tabular}

Frederickson 1995

\begin{tabular}{ll}
\hline Methods & RCT \\
\hline Participants & $\begin{array}{l}\text { Setting: One general practice, UK. } \\
\text { Clinician: One general practitioner. } \\
\text { Participants: Consecutive mixed adult patients; } 80 \text { recruited, randomised and completed follow up }\end{array}$ \\
\hline Interventions & $\begin{array}{l}\text { Timing: Immediately before consultation. } \\
\text { Intervention: Leaflet - single page encouraging patient to 'stop, think and tell' the doctor about the problem } \\
\text { and their concerns } \\
\text { Controls: Usual care. } \\
\text { Clinician: Usual practice. }\end{array}$ \\
\hline Outcomes & $\begin{array}{l}\text { Clinician questionnaire: } \\
\text { Rating of quality of consultation (good/not good) }\end{array}$ \\
\hline Notes & \\
\hline
\end{tabular}

\section{Risk of bias}

Item

Authors' judgement Description 
Frederickson 1995 (Continued)

\begin{tabular}{|c|c|c|}
\hline Allocation concealment? & No & C - Inadequate \\
\hline
\end{tabular}

\section{Greenfield 1985}

\begin{tabular}{|c|c|c|}
\hline Methods & \multicolumn{2}{|l|}{ RCT } \\
\hline Participants & \multicolumn{2}{|c|}{$\begin{array}{l}\text { Setting: One outpatient clinic, USA. } \\
\text { Clinicians: } 8 \text { physicians. } \\
\text { Participants: Adults with peptic ulcers; } 87 \text { eligible, } 51 \text { made clinic visits, } 45 \text { randomised ( } 6 \text { excluded), } 4 \\
\text { completed follow up }\end{array}$} \\
\hline Interventions & \multicolumn{2}{|c|}{$\begin{array}{l}\text { Timing: Immediately before consultation. } \\
\text { Intervention: Coaching - } 20 \text { minute session with } 3 \text { components - review of records, review of treatment } \\
\text { algorithm, behaviour change strategy to increase involvement in consultation } \\
\text { Controls: Similar intervention covering review of ulcer disease } \\
\text { Clinicians: Usual practice. }\end{array}$} \\
\hline Outcomes & \multicolumn{2}{|c|}{$\begin{array}{l}\text { Consultation audiotape: } \\
\text { Consultation length } \\
\text { Questions asked } \\
\text { Patient utterances } \\
\text { Controlling utterances by patient } \\
\text { Patient: physician utterances } \\
\text { Physician fact: control utterances } \\
\text { Exit questionnaire: } \\
\text { Knowledge ( } 23 \text { items) } \\
\text { Postal questionnaire (6-8 weeks): } \\
\text { Role limitations ( } 3 \text { items) } \\
\text { Physical limitations ( } 5 \text { items) } \\
\text { Ulcer related pain ( } 9 \text { items) } \\
\text { Preference for active involvement (5 items) } \\
\text { Satisfaction (4 items) }\end{array}$} \\
\hline Notes & \multicolumn{2}{|c|}{ Intervention for controls could affect outcome of knowledge. } \\
\hline \multicolumn{3}{|l|}{ Risk of bias } \\
\hline Item & Authors' judgement & Description \\
\hline Allocation concealment? & Unclear & B - Unclear \\
\hline
\end{tabular}


Greenfield 1988

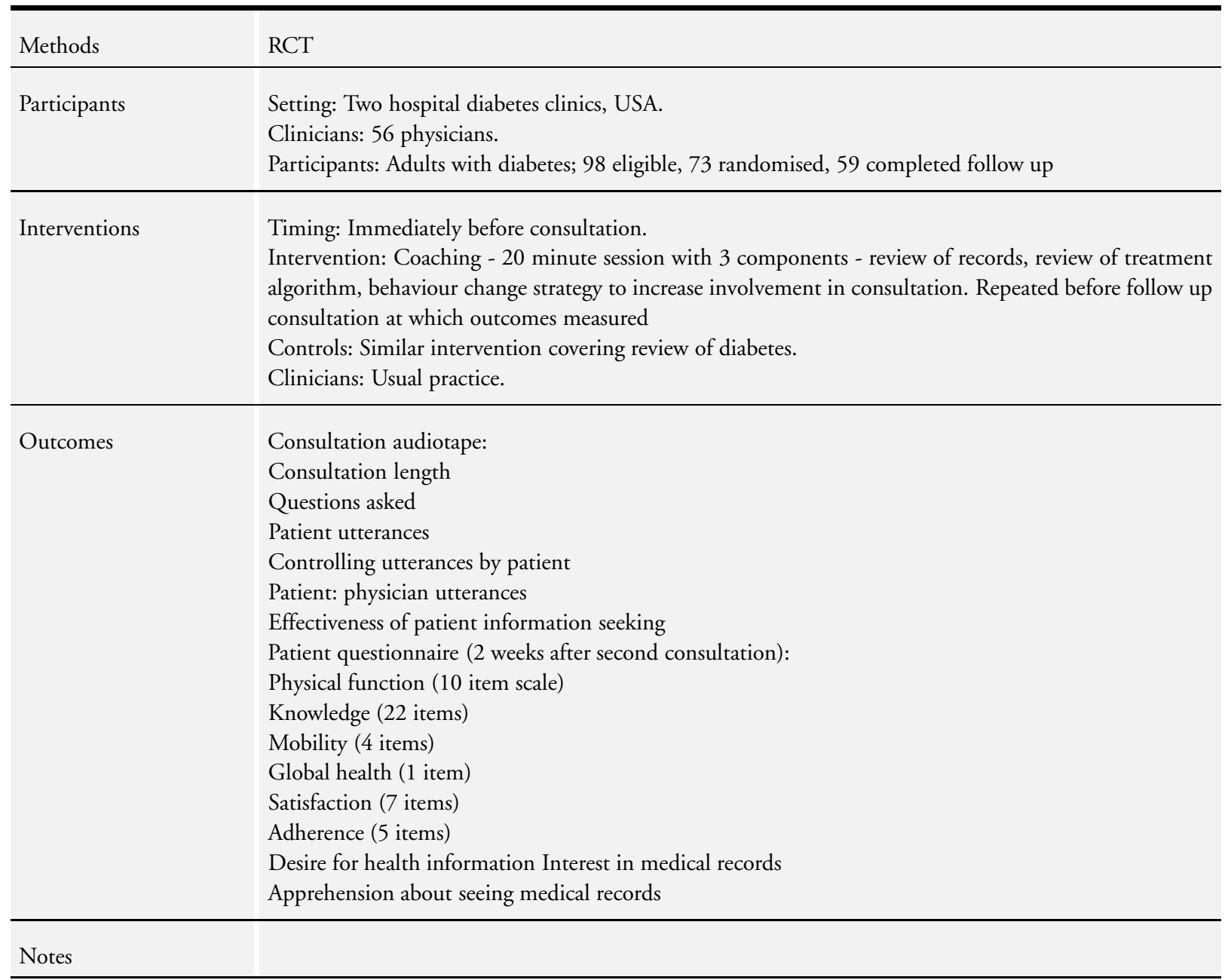

\section{Risk of bias}

\begin{tabular}{|c|c|c|}
\hline Item & Authors' judgement & Description \\
\hline Allocation concealment? & Unclear & B - Unclear \\
\hline
\end{tabular}

\section{Hornberger 1997}

\begin{tabular}{l|l}
\hline Methods & $\begin{array}{l}\text { RCT } \\
\text { Randomisation by clinician. }\end{array}$ \\
\hline Participants & $\begin{array}{l}\text { Setting: One primary care clinic, USA. } \\
\text { Clinicians: } 15 \text { physicians approached, } 10 \text { participated in trial (5 refused) } \\
\text { Participants: adults with mixed primary care problems; } 221 \text { identified, } 102 \text { entered into trial }\end{array}$
\end{tabular}


Hornberger 1997 (Continued)

\begin{tabular}{|c|c|c|}
\hline Interventions & \multicolumn{2}{|c|}{$\begin{array}{l}\text { Timing: Immediately before consultation. } \\
\text { Intervention: question prompt sheet - questionnaire identifying patient concerns with encouragement to } \\
\text { ask questions. Patients identified three main concerns and wrote these down. This list attached to patient } \\
\text { records so physician could address it } \\
\text { Controls: Pamphlet about hospital and clinic. } \\
\text { Clinicians: Usual practice. }\end{array}$} \\
\hline Outcomes & \multicolumn{2}{|c|}{$\begin{array}{l}\text { Consultation audiotape: } \\
\text { Number of diagnoses } \\
\text { Consultation length } \\
\text { Exit questionnaire: } \\
\text { Health status (SF 36) } \\
\text { Anxiety (HAD - no of items not provided) } \\
\text { Depression (HAD - no of items not provided) } \\
\text { Satisfaction (4 items) } \\
\text { Provision of services in consultation } \\
\text { Clinician questionnaire: Satisfaction (6 items) }\end{array}$} \\
\hline \multicolumn{3}{|l|}{ Notes } \\
\hline \multicolumn{3}{|l|}{ Risk of bias } \\
\hline Item & Authors' judgement & Description \\
\hline Allocation concealment? & No & $\mathrm{C}$ - Inadequate \\
\hline
\end{tabular}

Kidd 2004

\begin{tabular}{ll}
\hline Methods & $\begin{array}{l}\text { RCT } \\
\text { Three intervention and two control groups. }\end{array}$ \\
\hline Participants & $\begin{array}{l}\text { Setting: One diabetes clinic, UK. } \\
\text { Clinicians: Number not stated. } \\
\text { Participants: Adults with diabetes; } 332 \text { approached, } 202 \text { randomised and entered into study (93 refused, } \\
37 \text { withdrew) and completed follow up }\end{array}$ \\
\hline Interventions & $\begin{array}{l}\text { Timing: Immediately before consultation. } \\
\text { Interventions: a) Question encouragement - encouraged to ask questions by written message; b) Question } \\
\text { prompt interview - five minutes with researcher identifying at least three questions to ask; c) Question } \\
\text { prompt interview/Coaching - question identification and rehearsal of question asking } \\
\text { Controls: a) Discussion of layout of hospital and clinic; b) Usual care } \\
\text { Clinicians: Usual practice }\end{array}$ \\
\hline Outcomes & $\begin{array}{l}\text { Consultation audiotape: } \\
\text { Question asking } \\
\text { Exit questionnaire: } \\
\text { Self efficacy (2 items) } \\
\text { Satisfaction (1 item) }\end{array}$ \\
\hline
\end{tabular}


Postal questionnaire (3 months after consultation):

Self efficacy (2 items)

Satisfaction (1 item)

Physiological test: HbAlc

\section{Notes}

\section{Risk of bias}

\begin{tabular}{l|ll}
\hline Item & Authors' judgement & Description \\
\hline Allocation concealment? & Unclear & B - Unclear \\
\hline
\end{tabular}

Kim 2003

\begin{tabular}{|c|c|}
\hline Methods & $\begin{array}{l}\text { RCT } \\
12 \text { patients per clinician, balanced so that there were } 4 \text { new patients and } 8 \text { returning patients per clinician }\end{array}$ \\
\hline Participants & $\begin{array}{l}\text { Setting: } 64 \text { family planning clinics, Indonesia. } \\
\text { Clinicians: } 64 \text { family planning providers. } \\
\text { Participants: Women attending family planning clinics; } 768 \text { recruited, randomised and completed follow } \\
\text { up }\end{array}$ \\
\hline Interventions & $\begin{array}{l}\text { Timing: Immediately before consultation. } \\
\text { Intervention: Coaching/leaflet - individual 'Smart Patient' coaching and leaflet to identify questions to } \\
\text { ask and how to ask questions } \\
\text { Controls: Leaflet on HIV/AIDS and session with educator to answer questions } \\
\text { Clinicians: Usual practice. }\end{array}$ \\
\hline Outcomes & $\begin{array}{l}\text { Consultation audiotape: } \\
\text { Consultation length } \\
\text { Questions asked } \\
\text { Participation in consultation } \\
\text { Exit interview: } \\
\text { Assessment of communication (no of items not provided) } \\
\text { Patient follow up (8 months, new patients only): } \\
\text { Contraceptive use }\end{array}$ \\
\hline \multicolumn{2}{|l|}{ Notes } \\
\hline \multicolumn{2}{|l|}{ Risk of bias } \\
\hline Item & Authors' judgement \\
\hline Allocation concealment? & B - Unclear \\
\hline
\end{tabular}


Lewis 1991

\begin{tabular}{ll} 
Methods & $\begin{array}{l}\text { RCT } \\
\text { Randomisation by clinician. }\end{array}$ \\
\hline Participants & $\begin{array}{l}\text { Setting: Three university paediatric clinics, USA. } \\
\text { Clinicians: } 56 \text { residents randomised but only } 34 \text { actually involved in study } \\
\text { Participants: Children and their parents; } 141 \text { recruited and followed up (about 20\% refused to participate) }\end{array}$ \\
\hline Interventions & $\begin{array}{l}\text { Timing: Immediately before consultation. } \\
\text { Interventions: Video/workbook/coaching - three facets targeted at child, parent and clinician. } \\
\text { Child: } 10 \text { minute video and workbook to encourage question asking and to write down questions. Practised } \\
\text { asking questions with research assistant. } \\
\text { Parents: } 10 \text { minute video. } \\
\text { Controls: Children - video on bicycle safety and workbook. Parents: Video on bicycle safety } \\
\text { Clinicians: Randomised into groups - Intervention - One hour training session including } 15 \text { minute video } \\
\text { with training 'boosters' at 3, } 8 \text { and } 15 \text { months. } \\
\text { Controls: Educational session including video on management of febrile convulsions }\end{array}$ \\
\hline Consultation videotape: \\
Child participation in consultation \\
$\begin{array}{l}\text { Exit questionnaire: } \\
\text { Recall (General and medication recommendations) } \\
\text { Child's Health related attitudes and behaviour (20 items) } \\
\text { Child Satisfaction (no of items not provided) } \\
\text { Parent satisfaction (no of items not provided) } \\
\text { Child anxiety (8 items) } \\
\text { Clinician questionnaire: Satisfaction (13 items) }\end{array}$ \\
\hline Notes & \begin{tabular}{l} 
Cutcomes \\
\hline
\end{tabular} \\
\hline
\end{tabular}

Risk of bias

\begin{tabular}{lll}
\hline Item & Authors' judgement & Description \\
\hline Allocation concealment? & Unclear & B - Unclear \\
\hline
\end{tabular}

\section{Little 2004}

\begin{tabular}{ll} 
Methods & $\begin{array}{l}\text { RCT } \\
\text { Four groups: intervention leaflet, another leaflet, both, neither }\end{array}$ \\
\hline Participants & $\begin{array}{l}\text { Setting: } 5 \text { general practices, UK. } \\
\text { Clinicians: Number not stated. } \\
\text { Participants: Adults with mixed primary care problems; } 636 \text { recruited and randomised, } 485 \text { completed } \\
\text { follow up }\end{array}$ \\
\hline Interventions & $\begin{array}{l}\text { Timing: Immediately before consultation. } \\
\text { Intervention: Leaflet - asking patient to list issues they wanted to raise and explaining that the clinician } \\
\text { wanted them to talk, discuss and ask questions. For half the patients, a second leaflet on depression was } \\
\text { provided }\end{array}$
\end{tabular}


Little 2004 (Continued)

Controls: Group 1: Leaflet listing symptoms of depression, asking patient if had these and telling them that clinician would like to discuss these.

Group 2: Usual care.

Clinicians: Usual practice.

\begin{tabular}{ll} 
Outcomes & Exit questionnaire: \\
Satisfaction (no of items not provided) & Anxiety (HADS - no of items not provided) \\
Depression (HADS - no of items not provided) \\
State Anxiety Inventory (no of items not provided) \\
Enablement (no of items not provided) \\
Resolution of symptoms (MYMOP - no of items not provided) \\
Clinician questionnaire: \\
Consultation length \\
Number of investigations \\
Pressure from patient for investigations \\
\hline
\end{tabular}

Notes

Risk of bias

\begin{tabular}{l|ll}
\hline Item & Authors' judgement & Description \\
\hline Allocation concealment? & Yes & A - Adequate \\
\hline
\end{tabular}

\section{Maly 1999}

\begin{tabular}{ll}
\hline Methods & RCT \\
\hline Participants & $\begin{array}{l}\text { Setting: One family practice clinic, USA. } \\
\text { Clinicians: } 35 \text { physicians. } \\
\text { Participants: Adults with mixed problems attending for two consultations; } 276 \text { eligible, } 265 \text { recruited, } \\
205 \text { followed up (56 did not attend for second consultation) }\end{array}$ \\
\hline Interventions & $\begin{array}{l}\text { Timing: Immediately before each of two consultations. } \\
\text { Intervention: Question prompt sheet - question list telling patient to write down the two main questions } \\
\text { they wanted to ask, also given copy of previous entry into medical records. Intervention repeated at second } \\
\text { linked consultation } \\
\text { Controls: Asked to write down two main improvements for clinic, also got health education sheet } \\
\text { Clinicians: Usual practice. }\end{array}$ \\
\hline Outcomes & $\begin{array}{l}\text { Consultation length } \\
\text { Patient questionnaire (2 weeks after second consultation): } \\
\text { Physical function (10 item scale) } \\
\text { Mobility (4 items) } \\
\text { Global health (1 item) } \\
\text { Satisfaction (7 items) } \\
\text { Adherence (5 items) }\end{array}$ \\
\hline
\end{tabular}


Desire for health information Interest in medical records (6 items)

Apprehension about seeing medical records (no of items not provided)

\section{Notes}

Risk of bias

\begin{tabular}{|c|c|c|}
\hline Item & Authors' judgement & Description \\
\hline Allocation concealment? & No & $\mathrm{C}$ - Inadequate \\
\hline
\end{tabular}

Martinali 2001

\begin{tabular}{|c|c|c|}
\hline Methods & \multicolumn{2}{|l|}{ RCT } \\
\hline Participants & \multicolumn{2}{|c|}{$\begin{array}{l}\text { Setting: One university cardiology clinic, the Netherlands. } \\
\text { Clinicians: } 14 \text { cardiologists. } \\
\text { Participants: Adult patients with mixed cardiac problems; } 168 \text { contacted, } 142 \text { randomised ( } 26 \text { refused), } \\
103 \text { completed follow up ( } 17 \text { did not attend, } 15 \text { declined on attending, } 7 \text { incomplete follow up) }\end{array}$} \\
\hline Interventions & \multicolumn{2}{|c|}{$\begin{array}{l}\text { Timing: One week before consultation. } \\
\text { Intervention: Question prompt sheet/information booklet - list of frequently asked questions and infor- } \\
\text { mation book about heart disease } \\
\text { Controls: Information booklet alone (Brochure from Dutch Heart Foundation on coronary artery disease) } \\
\text { Clinicians: Usual practice. }\end{array}$} \\
\hline Outcomes & \multicolumn{2}{|c|}{$\begin{array}{l}\text { Pre consultation questionnaire: } \\
\text { Anxiety (Spielberger } 20 \text { items) } \\
\text { Exit questionnaire: } \\
\text { Adequacy of information exchange (10 items) } \\
\text { Perception of participation ( } 2 \text { items) } \\
\text { Knowledge ( } 25 \text { items) } \\
\text { Satisfaction (18 items) } \\
\text { Clinician questionnaire: } \\
\text { Consultation length }\end{array}$} \\
\hline \multicolumn{3}{|l|}{ Notes } \\
\hline \multicolumn{3}{|l|}{ Risk of bias } \\
\hline Item & Authors' judgement & Description \\
\hline Allocation concealment? & Unclear & B - Unclear \\
\hline
\end{tabular}


McCann 1996

\begin{tabular}{|c|c|}
\hline Methods & RCT \\
\hline Participants & $\begin{array}{l}\text { Setting: One general practice, UK. } \\
\text { Clinician: One general practitioner. } \\
\text { Participants: Adult patients with mixed problems; } 163 \text { approached, } 120 \text { randomised and followed up ( } 43 \\
\text { refused) }\end{array}$ \\
\hline Interventions & $\begin{array}{l}\text { Timing: Immediately before consultation. } \\
\text { Intervention: Question prompt sheet - 'Speak for yourself' leaflet containing encouragement to ask ques- } \\
\text { tions and space to write down own questions } \\
\text { Controls: Leaflet on healthy eating. } \\
\text { Clinician: Usual practice. }\end{array}$ \\
\hline Outcomes & $\begin{array}{l}\text { Consultation audiotape: } \\
\text { Consultation length } \\
\text { Questions asked } \\
\text { Exit questionnaire: } \\
\text { Satisfaction (26 items) } \\
\text { Health status (SF36) } \\
\text { Patient questionnaire (4 weeks) } \\
\text { Health status (SF36) } \\
\text { Clinician questionnaire: } \\
\text { Rating of consultation (3 items) } \\
\text { Record review (12 months): } \\
\text { Number of consultations }\end{array}$ \\
\hline
\end{tabular}

\section{Risk of bias}

\begin{tabular}{|c|c|c|}
\hline Item & Authors' judgement & Description \\
\hline Allocation concealment? & Unclear & B - Unclear \\
\hline
\end{tabular}

Middleton 2006

\begin{tabular}{ll}
\hline Methods & RCT \\
\hline Participants & $\begin{array}{l}\text { Setting: general practices, UK. } \\
\text { Clinicians: } 46 \text { general practitioners. } \\
\text { Participants: Adults with mixed problems, } 971 \text { randomised, } 857 \text { completed followed up }\end{array}$ \\
\hline Interventions & $\begin{array}{l}\text { Timing: Immediately before the consultation. } \\
\text { Intervention: Patient agenda form asking patients to identify questions they wanted to ask } \\
\text { Controls: Usual care. } \\
\text { Clinicians: Randomised so that half received training to increase awareness of the patient agenda model } \\
\text { in consultations }\end{array}$
\end{tabular}


Middleton 2006 (Continued)

\begin{tabular}{|c|c|c|}
\hline Outcomes & \multicolumn{2}{|c|}{$\begin{array}{l}\text { Exit questionnaire: } \\
\text { Patient satisfaction - four components (each single item) } \\
\text { general satisfaction } \\
\text { professional care } \\
\text { perceived time } \\
\text { depth of relationship } \\
\text { Clinician questionnaire: } \\
\text { Number of problems identified } \\
\text { Consultation length }\end{array}$} \\
\hline \multicolumn{3}{|l|}{ Notes } \\
\hline \multicolumn{3}{|l|}{ Risk of bias } \\
\hline Item & Authors' judgement & Description \\
\hline Allocation concealment? & Yes & A - Adequate \\
\hline
\end{tabular}

Oliver 2001

\begin{tabular}{ll}
\hline Methods & RCT \\
\hline Participants & $\begin{array}{l}\text { Setting: Two cancer clinics, USA. } \\
\text { Clinicians: } 8 \text { oncologists. } \\
\text { Participants: adults with moderate cancer pain; } 355 \text { suitable, } 87 \text { randomised (177 refused, } 91 \text { deferred), } \\
78 \text { attended and entered into study, } 67 \text { completed follow up }\end{array}$ \\
\hline Interventions & $\begin{array}{l}\text { Timing: Immediately before consultation. } \\
\text { Intervention: Coaching/booklet - patients taught practical pain management techniques and empowered } \\
\text { to participate actively in their own care. Booklet had space to write down questions } \\
\text { Controls: Education on controlling cancer pain. } \\
\text { Clinicians: Usual practice. }\end{array}$ \\
\hline Outcomes & $\begin{array}{l}\text { Patient interview (by telephone at two weeks): } \\
\text { Average pain (1 item) } \\
\text { Pain related impairment (6 items) } \\
\text { Pain frequency (1 item) } \\
\text { Pain related knowledge (6 items) } \\
\text { Adherence to analgesic regime }(1 \text { item) }\end{array}$ \\
\hline Notes & \begin{tabular}{l} 
\\
\hline
\end{tabular} \\
\hline
\end{tabular}

\section{Risk of bias}

\begin{tabular}{l|l|l}
\hline Item & Authors' judgement & Description \\
\hline Allocation concealment? & Unclear & B - Unclear \\
\hline
\end{tabular}


Roter 1977

\begin{tabular}{|c|c|c|}
\hline Methods & \multicolumn{2}{|l|}{ RCT } \\
\hline Participants & \multicolumn{2}{|c|}{$\begin{array}{l}\text { Setting: One family practice centre, USA. } \\
\text { Clinicians: Two physicians and one nurse practitioner. } \\
\text { Participants: Adults with mixed problems; } 294 \text { 'took part in study,' } 200 \text { randomised }\end{array}$} \\
\hline Interventions & \multicolumn{2}{|c|}{$\begin{array}{l}\text { Timing: Immediately before consultation. } \\
\text { Intervention: Coaching - } 10 \text { minute session with health educator working through question-asking pro } \\
\text { tocol to identify patient's questions and practice how to ask them. Patients took list of questions intc } \\
\text { consultation } \\
\text { Controls: Similar session on use of healthcare facilities. } \\
\text { Clinicians: Usual practice. }\end{array}$} \\
\hline Outcomes & \multicolumn{2}{|c|}{$\begin{array}{l}\text { Consultation audiotape: } \\
\text { Questions asked } \\
\text { Consultation length } \\
\text { Bids for clarification } \\
\text { Patient information statements } \\
\text { Patient approval statements } \\
\text { Patient personal remarks } \\
\text { Provider personal statements } \\
\text { Provider questions } \\
\text { Provider opinion statements } \\
\text { Provider instructions } \\
\text { Provider approval statements } \\
\text { Provider agreement statements } \\
\text { Provider question requests } \\
\text { Patient anxiety } \\
\text { Patent anger } \\
\text { Patient matter of factness } \\
\text { Patient sympathy } \\
\text { Provider anxiety } \\
\text { Provider anger } \\
\text { Provider matter of factness } \\
\text { Provider sympathy } \\
\text { Exit interview: } \\
\text { Satisfaction (6 items) } \\
\text { Locus of control (no of items not provided) } \\
\text { Record review ( } 4 \text { months): } \\
\text { Appointments kept }\end{array}$} \\
\hline \multicolumn{3}{|l|}{ Notes } \\
\hline \multicolumn{3}{|l|}{ Risk of bias } \\
\hline Item & Authors' judgement & Description \\
\hline Allocation concealment? & Unclear & B - Unclear \\
\hline
\end{tabular}


Sander 1996a

\begin{tabular}{ll}
\hline Methods & $\begin{array}{l}\text { RCT } \\
\text { Two intervention groups. }\end{array}$ \\
\hline Participants & $\begin{array}{l}\text { Setting: One family practice clinic, USA. } \\
\text { Clinicians: } 18 \text { physicians. } \\
\text { Participants: Adult patients with mixed problems; } 129 \text { randomised }\end{array}$ \\
\hline Interventions & $\begin{array}{l}\text { Timing: Immediately before consultation. } \\
\text { Interventions: Question prompt sheets - two versions of health concerns card focusing on health mainte- } \\
\text { nance concerns and designed to stimulate the patient to seek further information } \\
\text { Controls: Usual care. } \\
\text { Clinicians: Usual practice. }\end{array}$ \\
\hline Outcomes & $\begin{array}{l}\text { Exit questionnaire: } \\
\text { Patient requests for information } \\
\text { Telephone interview (4 to } 6 \text { weeks): } \\
\text { Recall of information (no of items not provided) } \\
\text { Likelihood of using information to effect change (no of items not provided) } \\
\text { Perceptions of participation in consultation (no of items not provided) }\end{array}$ \\
\hline Notes & \begin{tabular}{l} 
\\
\hline
\end{tabular} \\
\hline
\end{tabular}

\section{Risk of bias}

\begin{tabular}{|c|c|c|}
\hline Item & Authors' judgement & Description \\
\hline Allocation concealment? & Unclear & B - Unclear \\
\hline
\end{tabular}

\section{Sander $1996 \mathrm{~b}$}

\begin{tabular}{ll}
\hline Methods & $\begin{array}{l}\text { RCT } \\
\text { Two intervention groups, patients randomised by day of consulting }\end{array}$ \\
\hline Participants & $\begin{array}{l}\text { Clinical setting: One family practice clinic, USA. } \\
\text { Clinicians: } 18 \text { physicians. } \\
\text { Participants: Adults consulting with mixed problems; } 163 \text { randomised }\end{array}$ \\
\hline Interventions & $\begin{array}{l}\text { Timing: Immediately before consultation. } \\
\text { Intervention: Coaching - two versions of } 5 \text { minute coaching with encouragement to identify and write } \\
\text { down questions } \\
\text { Controls: Usual care. } \\
\text { Clinicians: Usual practice. }\end{array}$ \\
\hline
\end{tabular}

$\begin{array}{ll}\text { Outcomes } & \text { Exit questionnaire: } \\ \text { Patient requests for information } \\ \text { Telephone interview (4 to } 6 \text { weeks): } \\ \text { Recall of information (no of items not provided) } \\ \text { Likelihood of using information to effect change (no of items not provided) }\end{array}$


Sander 1996b (Continued)

Perceptions of participation in consultation (no of items not provided)

\begin{tabular}{|c|c|c|}
\hline Notes & & \\
\hline \multicolumn{3}{|l|}{ Risk of bias } \\
\hline Item & Authors' judgement & Description \\
\hline Allocation concealment? & No & $\mathrm{C}$ - Inadequate \\
\hline
\end{tabular}

Tabak 1988

\begin{tabular}{ll}
\hline Methods & RCT \\
\hline Participants & $\begin{array}{l}\text { Setting: One family medicine clinic, USA . } \\
\text { Clinicians: 14 residents. } \\
\text { Patients: Adults with mixed problems; 141 eligible, 101 consented, 67 used (34 not used - audiotape } \\
\text { problems, drop outs) }\end{array}$ \\
\hline Interventions & $\begin{array}{l}\text { Timing: Immediately before consultation. } \\
\text { Intervention: Booklet - encouraging question asking. } \\
\text { Controls: Booklet on clinic hours and services. } \\
\text { Clinicians: Usual practice. }\end{array}$ \\
\hline Outcomes & $\begin{array}{l}\text { Consultation audiotape: } \\
\text { Question asking }\end{array}$ \\
\hline Notes & \begin{tabular}{l} 
Authors' judgement $\quad$ Description \\
\hline Risk of bias
\end{tabular} \\
\hline Item & Yes - Adequate \\
\hline
\end{tabular}

\section{Tennstedt 2000}

\begin{tabular}{ll} 
Methods & $\begin{array}{l}\text { RCT } \\
\text { Randomised by site. }\end{array}$ \\
\hline Participants & $\begin{array}{l}\text { Setting: } 36 \text { community sites, USA. } \\
\text { Clinicians: number not stated. } \\
\text { Participants: Older patients with mixed problems attending Family Practice clinics; } 355 \text { attended consul- } \\
\text { tations, } 345 \text { completed follow up }\end{array}$ \\
\hline Interventions & $\begin{array}{l}\text { Timing: Up to } 3 \text { months before consultation. } \\
\text { Intervention: Coaching/booklet - two hour programme with booklet to record questions for clinicians }\end{array}$
\end{tabular}


Controls: Usual care.

Clinicians: Usual practice.

\begin{tabular}{l|l}
\hline Outcomes & $\begin{array}{l}\text { Telephone interview: } \\
\text { Participation in consultation (no of items not provided) } \\
\text { Satisfaction (no of items not provided) }\end{array}$ \\
\hline Notes & \\
\hline
\end{tabular}

Notes

Risk of bias

\begin{tabular}{lll}
\hline Item & Authors' judgement & Description \\
\hline Allocation concealment? & No & C - Inadequate \\
\hline
\end{tabular}

Thompson 1990a

\begin{tabular}{|c|c|c|}
\hline Methods & \multicolumn{2}{|l|}{ RCT } \\
\hline Participants & \multicolumn{2}{|c|}{$\begin{array}{l}\text { Setting: One obstetric and gynaecology clinic, USA. } \\
\text { Clinicians: One obstetrician/gynaecologist. } \\
\text { Participants: Women with obstetric and gynaecology problems; } 66 \text { recruited, } 53 \text { completed follow up }\end{array}$} \\
\hline Interventions & \multicolumn{2}{|c|}{$\begin{array}{l}\text { Timing: Immediately before consultation. } \\
\text { Intervention: Question prompt sheet - list of possible health concerns with instructions to write down at } \\
\text { least } 3 \text { questions for the clinician } \\
\text { Controls: Questionnaire about the waiting room. } \\
\text { Clinician: Usual practice. }\end{array}$} \\
\hline Outcomes & \multicolumn{2}{|c|}{$\begin{array}{l}\text { Consultation length } \\
\text { Exit questionnaire: } \\
\text { Questions asked } \\
\text { State Anxiety (Spielberger - no of items not provided) } \\
\text { Satisfaction ( } 9 \text { items) } \\
\text { Clinician questionnaire: } \\
\text { Satisfaction ( } 2 \text { items) } \\
\text { Questions asked by patient (estimate) }\end{array}$} \\
\hline \multicolumn{3}{|l|}{ Notes } \\
\hline \multicolumn{3}{|l|}{ Risk of bias } \\
\hline Item & Authors' judgement & Description \\
\hline Allocation concealment? & Unclear & B - Unclear \\
\hline
\end{tabular}


Thompson 1990b

\begin{tabular}{|c|c|}
\hline Methods & $\begin{array}{l}\text { RCT } \\
\text { Two intervention groups. }\end{array}$ \\
\hline Participants & $\begin{array}{l}\text { Setting: One obstetric and gynaecology clinic, USA. } \\
\text { Clinicians: Two obstetrician/gynaecologists. } \\
\text { Participants: Women with obstetric and gynaecology problems; } 105 \text { recruited, } 49 \text { completed follow up }\end{array}$ \\
\hline Interventions & $\begin{array}{l}\text { Timing: Immediately before consultation. } \\
\text { Interventions: a) Question prompt sheet - list of possible health concerns with instructions to write down } \\
\text { at least } 3 \text { questions with checklist of information to obtain during consultation. b) Message - written } \\
\text { message that clinician wanted them to ask questions in the consultation } \\
\text { Controls: Questionnaire about the waiting room. } \\
\text { Clinicians: Usual practice. }\end{array}$ \\
\hline Outcomes & $\begin{array}{l}\text { Exit questionnaire: } \\
\text { Questions asked } \\
\text { Extent to which questions answered } \\
\text { Satisfaction ( } 9 \text { items) } \\
\text { Satisfaction with information received ( } 1 \text { item) } \\
\text { State Anxiety (Spielberger) } \\
\text { Sense of control (5 items) } \\
\text { Accuracy of recall } \\
\text { Confidence of recall (14 items) }\end{array}$ \\
\hline
\end{tabular}

\section{Risk of bias}

\begin{tabular}{|c|c|c|}
\hline Item & Authors' judgement & Description \\
\hline Allocation concealment? & Unclear & B - Unclear \\
\hline
\end{tabular}

Wilkinson 2002

\begin{tabular}{ll}
\hline Methods & RCT \\
\hline Participants & $\begin{array}{l}\text { Setting: One primary care clinic, USA. } \\
\text { Clinicians: Number not stated. } \\
\text { Participants: Veterans with mixed problems attending primary care team visits; } 278 \text { selected and ran- } \\
\text { domised, 277 participated, follow up unclear }\end{array}$ \\
\hline Interventions & $\begin{array}{l}\text { Intervention: 'Appointment guidebook' with suggestions as to how to prepare for consultation including } \\
\text { space to write down questions } \\
\text { Controls: Usual care. } \\
\text { Clinicians: Usual practice. }\end{array}$ \\
\hline Outcomes & $\begin{array}{l}\text { Patient questionnaire (few days after consultation): } \\
\text { Evaluation of visit (5 items) } \\
\text { Record review: }\end{array}$
\end{tabular}


Wilkinson 2002 (Continued)

Health promotion interventions

\begin{tabular}{lll}
\hline Notes & \\
\hline Risk of bias & \\
\hline Item & Authors' judgement & Description \\
\hline Allocation concealment? & Unclear & B - Unclear \\
\hline
\end{tabular}

\section{Characteristics of excluded studies [ordered by study ID]}

\begin{tabular}{|c|c|}
\hline Study & Reason for exclusion \\
\hline Ader 1992 & Not randomised trial \\
\hline Agre 1993 & Intervention not intended to change patient information seeking within consultation \\
\hline Albertson 2002 & Intervention not intended to change patient information seeking within consultation \\
\hline Ambler 1999 & Not randomised trial \\
\hline Anderson 1987 & Intervention not before a specific consultation \\
\hline Anderson 1995 & Intervention not before a specific consultation \\
\hline Bekker 1999 & Not randomised trial \\
\hline Belkora 2006 & Not randomised trial \\
\hline Bergus 2002 & Intervention not intended to change patient information seeking within consultation \\
\hline Bertakis 1977 & Intervention not before a specific consultation \\
\hline Cegala 2001 & Not randomised trial \\
\hline Courtney 1997 & Intervention not before a specific consultation \\
\hline Cull 1998 & Intervention not intended to change patient information seeking within consultation \\
\hline Cunningham 2000 & Not randomised trial \\
\hline Done 1998 & Intervention not before a specific consultation \\
\hline Dow 1991 & Intervention not before a specific consultation \\
\hline
\end{tabular}


(Continued)

\begin{tabular}{|c|c|}
\hline Fleissig 2001 & Intervention not intended to change patient information seeking within consultation \\
\hline Greaves 1999 & Intervention not before a specific consultation \\
\hline Gustafson 1999 & Intervention not before a specific consultation \\
\hline Hardy 2001 & Intervention not intended to change patient information seeking within consultation \\
\hline Harmsen 2005 & Intervention not intended to change patient information seeking within consultation \\
\hline Inui 1979 & Intervention not intended to change patient information seeking within consultation \\
\hline Jenkinson 1988 & Intervention not before a specific consultation \\
\hline Jensen 1993 & Intervention not intended to change patient information seeking within consultation \\
\hline Jones 2002 & Not randomised trial \\
\hline Kaplan 1989 & $\begin{array}{l}\text { This paper describes } 4 \text { studies - two are by Greenfield already included in review separately, a third is RCT } \\
\text { but data cannot be disaggregated from other trials, fourth trial is non-randomised }\end{array}$ \\
\hline Keeble 2002 & Intervention not intended to change patient information seeking within consultation \\
\hline Kennedy 2002 & Intervention not intended to change patient information seeking within consultation \\
\hline Kennedy $2002 \mathrm{a}$ & Intervention not intended to change patient information seeking within consultation \\
\hline Kennedy 2004 & Intervention not intended to change patient information seeking within consultation \\
\hline Kitai 2002 & Intervention not before a specific consultation \\
\hline Kruijff 1997 & Not randomised trial \\
\hline Kupst 1975 & Intervention not before a specific consultation \\
\hline Kutner 1999 & Intervention not intended to change patient information seeking within consultation \\
\hline Madden 1994 & Intervention not intended to change patient information seeking within consultation \\
\hline McGee 1998 & Not randomised trial \\
\hline Middleton 1995 & Not randomised trial \\
\hline Miller 1986 & Intervention not before a specific consultation \\
\hline O’Mara 2003 & Intervention not intended to change patient information seeking within consultation \\
\hline
\end{tabular}


(Continued)

\begin{tabular}{|c|c|}
\hline Oermann 2003 & Not randomised trial \\
\hline Pasacreta 1998 & Not randomised trial \\
\hline Post 2002 & Not a trial - a review \\
\hline Pruyn 2004 & Intervention not intended to change patient information seeking within consultation \\
\hline Richard 1998 & Not randomised trial \\
\hline Rieger 1999 & Intervention not intended to change patient information seeking within consultation \\
\hline Robinson 1985 & Not randomised trial \\
\hline Rost 1991 & Intervention not before a specific consultation \\
\hline Ruland 2003 & Intervention not intended to change patient information seeking within consultation \\
\hline Rutten 1991 & Intervention not intended to change patient information seeking within consultation \\
\hline Rutten 1993 & Intervention not before a specific consultation \\
\hline Schouten 2005 & Intervention not intended to change patient information seeking within consultation \\
\hline Selvachandran 2002 & Intervention not intended to change patient information seeking within consultation \\
\hline Sepuchra 2000 & Not randomised trial \\
\hline Sepuchra 2002 & Not randomised trial \\
\hline Sepuchra 2003 & Not randomised trial \\
\hline Shepperd 1995 & Decision aid \\
\hline Smith 1998 & Intervention not before a specific consultation \\
\hline Stapleton 2002 & Intervention not before a specific consultation \\
\hline Street 1995 & $\begin{array}{l}\text { No randomised controlled data for effects of encouraging question asking (both interventions explicitly en- } \\
\text { courage question asking) }\end{array}$ \\
\hline Sulmasy 1996 & Intervention not intended to change patient information seeking within consultation \\
\hline Teutsch 2003 & Not randomised trial \\
\hline Thomas 2000 & Intervention not intended to change patient information seeking within consultation \\
\hline
\end{tabular}


(Continued)

\begin{tabular}{ll}
\hline Tran 2004 & Not randomised trial \\
\hline Van Dam 2003 & Not randomised trial \\
\hline Velikova 2002 & Intervention not before a specific consultation \\
\hline Wallston 1979 & Intervention not before a specific consultation \\
\hline Weinberger 1998 & Not randomised trial \\
\hline Wells 2004 & Not randomised trial \\
\hline Wetzels 2005 & Intervention not intended to change patient information seeking within consultation \\
\hline Wilson 2002 & Intervention not intended to change patient information seeking within consultation \\
\hline
\end{tabular}


DATA AND ANALYSES

Comparison 1. Intervention versus control

\begin{tabular}{lccll} 
Outcome or subgroup title & $\begin{array}{c}\text { No. of } \\
\text { studies }\end{array}$ & $\begin{array}{c}\text { No. of } \\
\text { participants }\end{array}$ & \multicolumn{1}{c}{ Statistical method } & Effect size \\
\hline 1 Question asking & 14 & 2020 & Std. Mean Difference (IV, Fixed, 95\% CI) & $0.27[0.19,0.36]$ \\
2 Anxiety (before consultation) & 3 & 372 & Mean Difference (IV, Random, 95\% CI) & $-1.56[-7.10,3.97]$ \\
3 Anxiety (after consultation) & 6 & 809 & Std. Mean Difference (IV, Fixed, 95\% CI) & $-0.08[-0.22,0.06]$ \\
4 Patient satisfaction & 17 & 3316 & Std. Mean Difference (IV, Fixed, 95\% CI) & $0.09[0.03,0.16]$ \\
5 Patient knowledge & 5 & 378 & Std. Mean Difference (IV, Random, 95\% CI) & $-0.34[-0.94,0.25]$ \\
6 Patient knowledge (omitting 2 & 3 & 231 & Std. Mean Difference (IV, Fixed, 95\% CI) & $-0.26[-0.52,0.01]$ \\
$\quad$ studies) & 13 & 3406 & Std. Mean Difference (IV, Random, 95\% CI) & $0.10[-0.05,0.25]$ \\
7 Consultation length & & &
\end{tabular}

Comparison 2. Written materials and coaching

\begin{tabular}{lccll} 
Outcome or subgroup title & $\begin{array}{c}\text { No. of } \\
\text { studies }\end{array}$ & $\begin{array}{c}\text { No. of } \\
\text { participants }\end{array}$ & Statistical method & Effect size \\
\hline 1 Question asking & 11 & & Std. Mean Difference (IV, Fixed, 95\% CI) & Subtotals only \\
1.1 Written materials & 6 & 563 & Std. Mean Difference (IV, Fixed, 95\% CI) & $0.42[0.26,0.59]$ \\
1.2 Coaching & 5 & 414 & Std. Mean Difference (IV, Fixed, 95\% CI) & $0.36[0.16,0.56]$ \\
2 Satisfaction & 16 & & Std. Mean Difference (IV, Fixed, 95\% CI) & Subtotals only \\
2.1 Written materials & 10 & 2354 & Std. Mean Difference (IV, Fixed, 95\% CI) & Not estimable \\
2.2 Coaching & 6 & 722 & Std. Mean Difference (IV, Fixed, 95\% CI) & $0.23[0.08,0.38]$ \\
3 Consultation length & 13 & & Std. Mean Difference (IV, Fixed, 95\% CI) & Subtotals only \\
3.1 Written materials & 10 & 2534 & Std. Mean Difference (IV, Fixed, 95\% CI) & $0.13[0.05,0.21]$ \\
3.2 Coaching & 3 & 872 & Std. Mean Difference (IV, Fixed, 95\% CI) & $0.07[-0.07,0.20]$ \\
\hline
\end{tabular}

Comparison 3. Timing

\begin{tabular}{|c|c|c|c|c|}
\hline Outcome or subgroup title & $\begin{array}{l}\text { No. of } \\
\text { studies }\end{array}$ & $\begin{array}{c}\text { No. of } \\
\text { participants }\end{array}$ & Statistical method & Effect size \\
\hline 1 Satisfaction & 17 & & Std. Mean Difference (IV, Fixed, 95\% CI) & Subtotals only \\
\hline $\begin{array}{l}\text { 1.1 Some time before } \\
\text { consultation }\end{array}$ & 2 & 208 & Std. Mean Difference (IV, Fixed, 95\% CI) & $0.07[-0.20,0.34]$ \\
\hline $\begin{array}{l}1.2 \text { Immediately before } \\
\text { consultation }\end{array}$ & 15 & 3108 & Std. Mean Difference (IV, Fixed, 95\% CI) & $0.10[0.02,0.17]$ \\
\hline 2 Consultation length & 13 & & Std. Mean Difference (IV, Random, 95\% CI) & Subtotals only \\
\hline $\begin{array}{l}2.1 \text { Some time before } \\
\text { consultation }\end{array}$ & 2 & 208 & Std. Mean Difference (IV, Random, 95\% CI) & $-0.04[-0.93,0.86]$ \\
\hline
\end{tabular}

Interventions before consultations for helping patients address their information needs (Review) 


\section{Comparison 4. Clinician training}

\begin{tabular}{cccll} 
Outcome or subgroup title & $\begin{array}{c}\text { No. of } \\
\text { studies }\end{array}$ & $\begin{array}{c}\text { No. of } \\
\text { participants }\end{array}$ & Statistical method & \multicolumn{1}{c}{ Effect size } \\
\hline 1 Satisfaction & 16 & & Std. Mean Difference (IV, Fixed, 95\% CI) & Subtotals only \\
1.1 Clinicians trained & 3 & 821 & Std. Mean Difference (IV, Fixed, 95\% CI) & $-0.01[-0.15,0.12]$ \\
1.2 Clinicians not trained & 15 & 2569 & Std. Mean Difference (IV, Fixed, 95\% CI) & $0.13[0.05,0.21]$ \\
2 Consultation length & 12 & & Std. Mean Difference (IV, Fixed, 95\% CI) & Subtotals only \\
2.1 Clinicians trained & 2 & 682 & Std. Mean Difference (IV, Fixed, 95\% CI) & $0.17[0.01,0.32]$ \\
2.2 Clinicians not trained & 12 & 2798 & Std. Mean Difference (IV, Fixed, 95\% CI) & $0.17[0.10,0.24]$ \\
\hline
\end{tabular}

\section{Analysis I.I. Comparison I Intervention versus control, Outcome I Question asking.}

Review: Interventions before consultations for helping patients address their information needs

Comparison: I Intervention versus control

Outcome: I Question asking

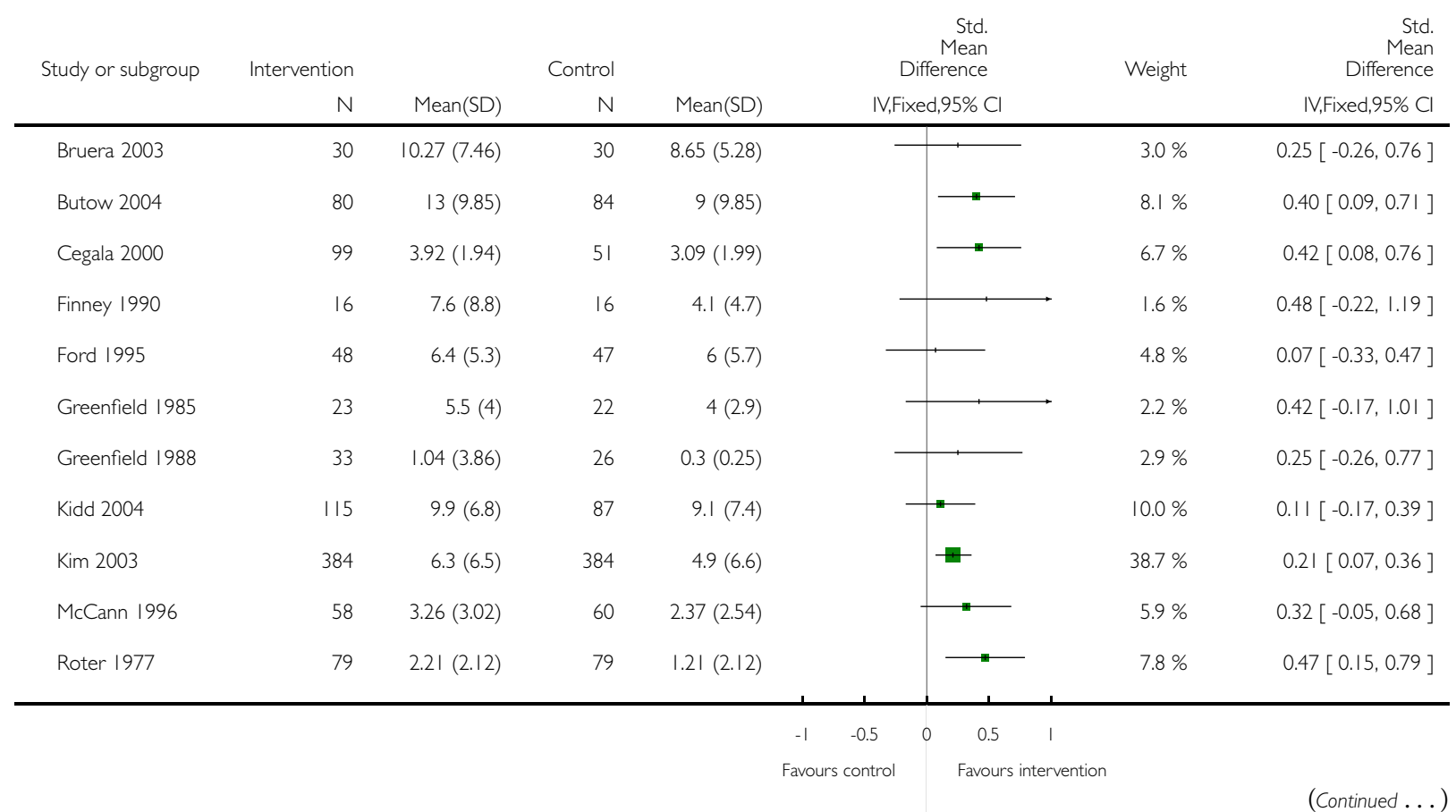




\begin{tabular}{|c|c|c|c|c|c|c|c|}
\hline \multirow[t]{2}{*}{ Study or subgroup } & Intervention & \multicolumn{3}{|c|}{ Control } & \multirow{2}{*}{$\begin{array}{r}\text { Std. } \\
\text { Mean } \\
\text { Difference } \\
\text { IV,Fixed,95\% Cl }\end{array}$} & \multirow[t]{2}{*}{ Weight } & $\begin{array}{r}\text { (... Continued } \\
\text { Std. } \\
\text { Mean } \\
\text { Difference }\end{array}$ \\
\hline & $\mathrm{N}$ & Mean(SD) & N & Mean(SD) & & & IV,Fixed,95\% Cl \\
\hline Tabak 1988 & 35 & $7.46(6.91)$ & 32 & $5.63(6.48)$ & 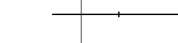 & $3.4 \%$ & $0.27[-0.21,0.75]$ \\
\hline Thompson 1990a & 29 & $4.5(1.5)$ & 24 & $3.5(1.6)$ & & $2.5 \%$ & $0.64[0.08,1.19]$ \\
\hline Thompson 1990b & 31 & $5.23(3.23)$ & 18 & $4.9(2.5)$ & & $2.3 \%$ & $0.11[-0.47,0.69]$ \\
\hline Total $(95 \%$ CI $)$ & 1060 & & 960 & & $\bullet$ & $100.0 \%$ & $0.27[0.19,0.36]$ \\
\hline \multicolumn{8}{|c|}{ Heterogeneity: $\mathrm{Chi}^{2}=8.42, \mathrm{df}=13(\mathrm{P}=0.82) ; \mathrm{I}^{2}=0.0 \%$} \\
\hline \multicolumn{8}{|c|}{ Test for overall effect: $Z=6.07(P<0.00001)$} \\
\hline \multicolumn{8}{|c|}{ Test for subgroup differences: Not applicable } \\
\hline
\end{tabular}

Analysis I.2. Comparison I Intervention versus control, Outcome 2 Anxiety (before consultation).

Review: Interventions before consultations for helping patients address their information needs

Comparison: I Intervention versus control

Outcome: 2 Anxiety (before consultation)

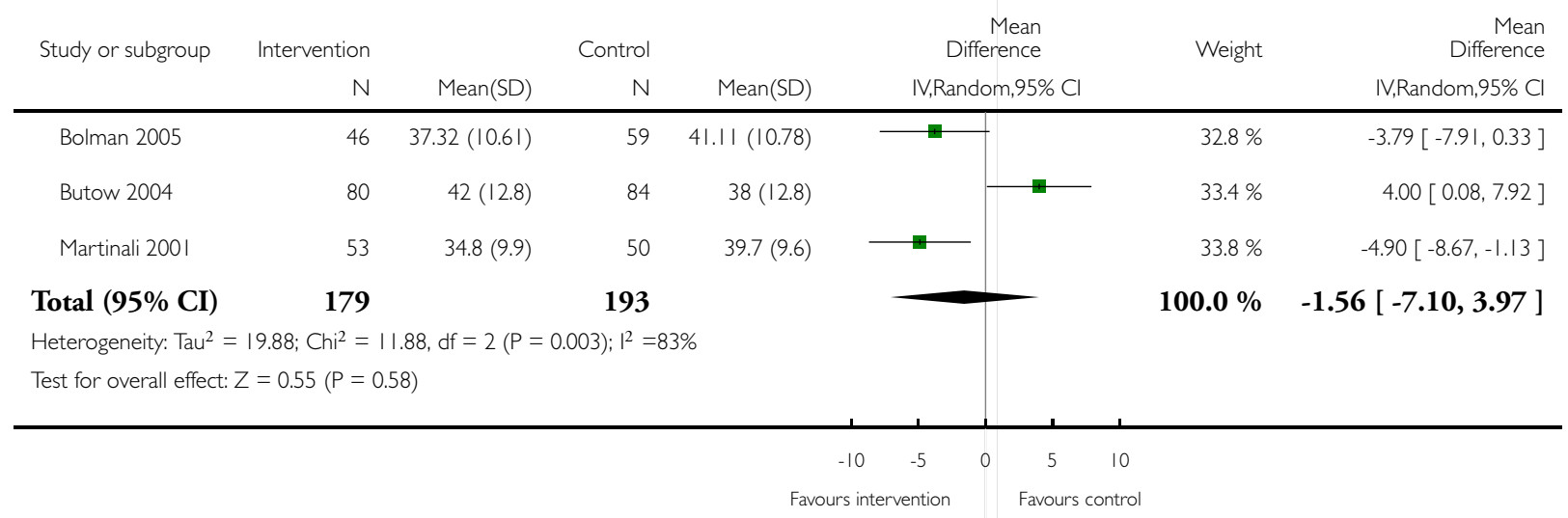




\section{Analysis I.3. Comparison I Intervention versus control, Outcome 3 Anxiety (after consultation).}

Review: Interventions before consultations for helping patients address their information needs

Comparison: I Intervention versus control

Outcome: 3 Anxiety (after consultation)

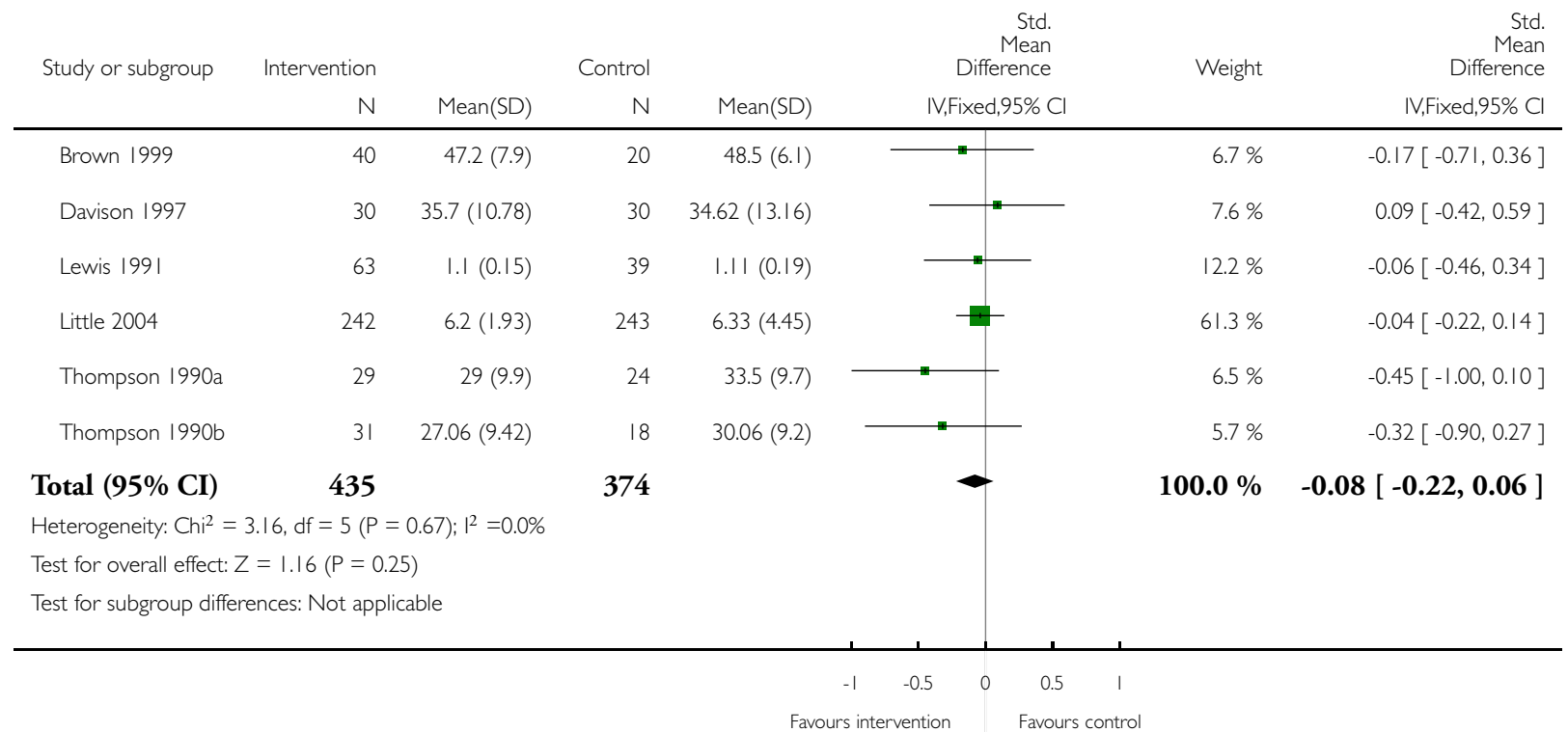




\section{Analysis I.4. Comparison I Intervention versus control, Outcome 4 Patient satisfaction.}

Review: Interventions before consultations for helping patients address their information needs

Comparison: I Intervention versus control

Outcome: 4 Patient satisfaction

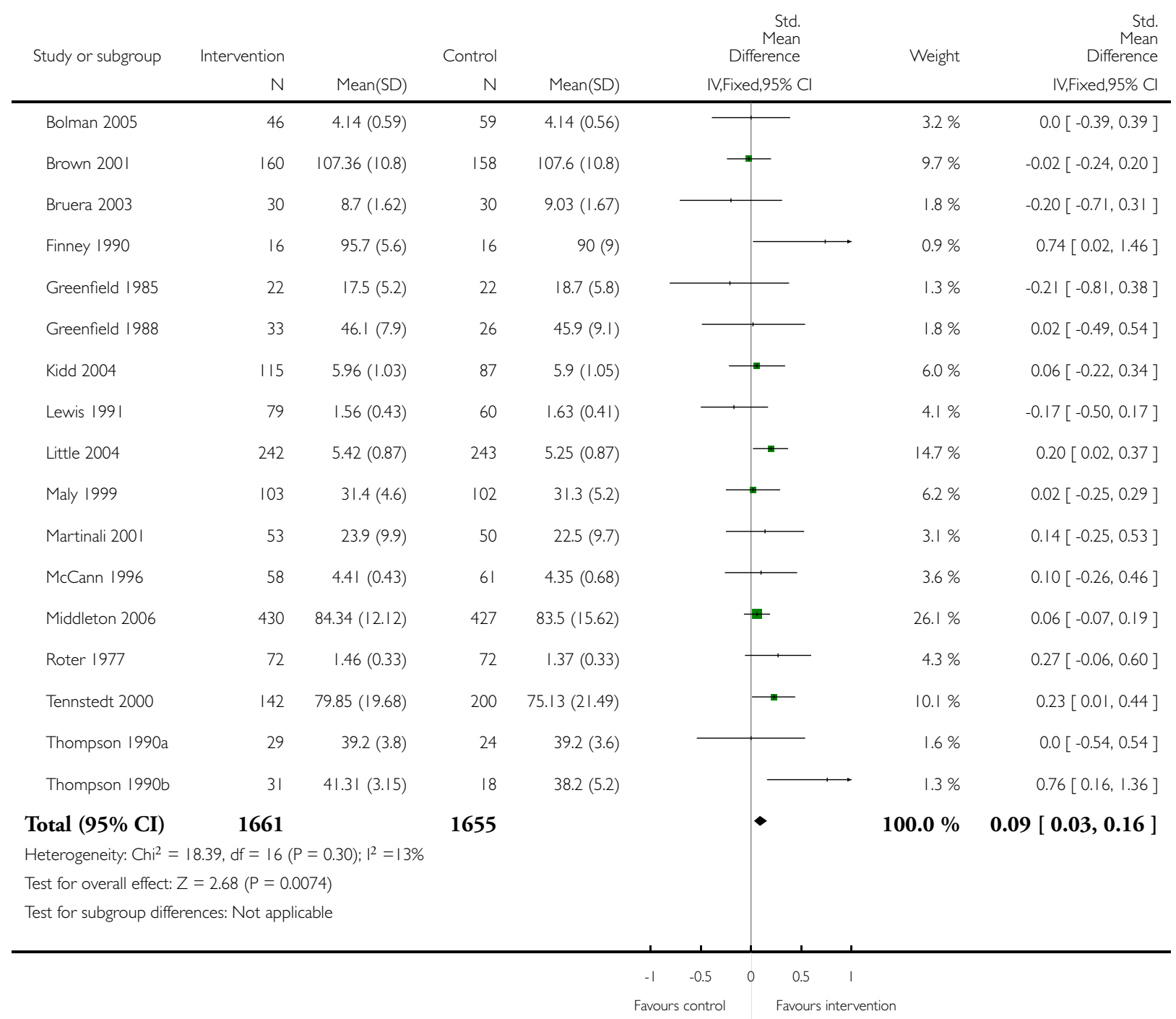




\section{Analysis I.5. Comparison I Intervention versus control, Outcome 5 Patient knowledge.}

Review: Interventions before consultations for helping patients address their information needs

Comparison: I Intervention versus control

Outcome: 5 Patient knowledge

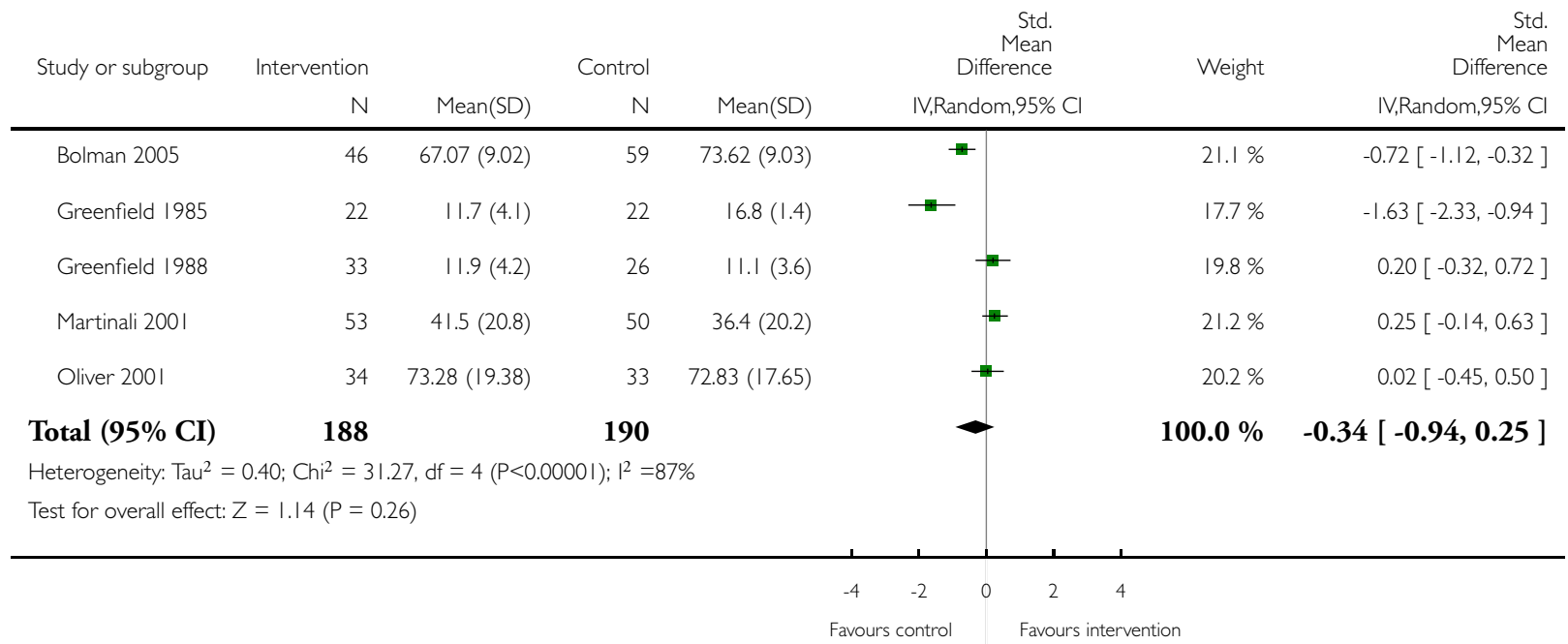

Analysis I.6. Comparison I Intervention versus control, Outcome 6 Patient knowledge (omitting 2 studies).

Review: Interventions before consultations for helping patients address their information needs

Comparison: I Intervention versus control

Outcome: 6 Patient knowledge (omitting 2 studies)

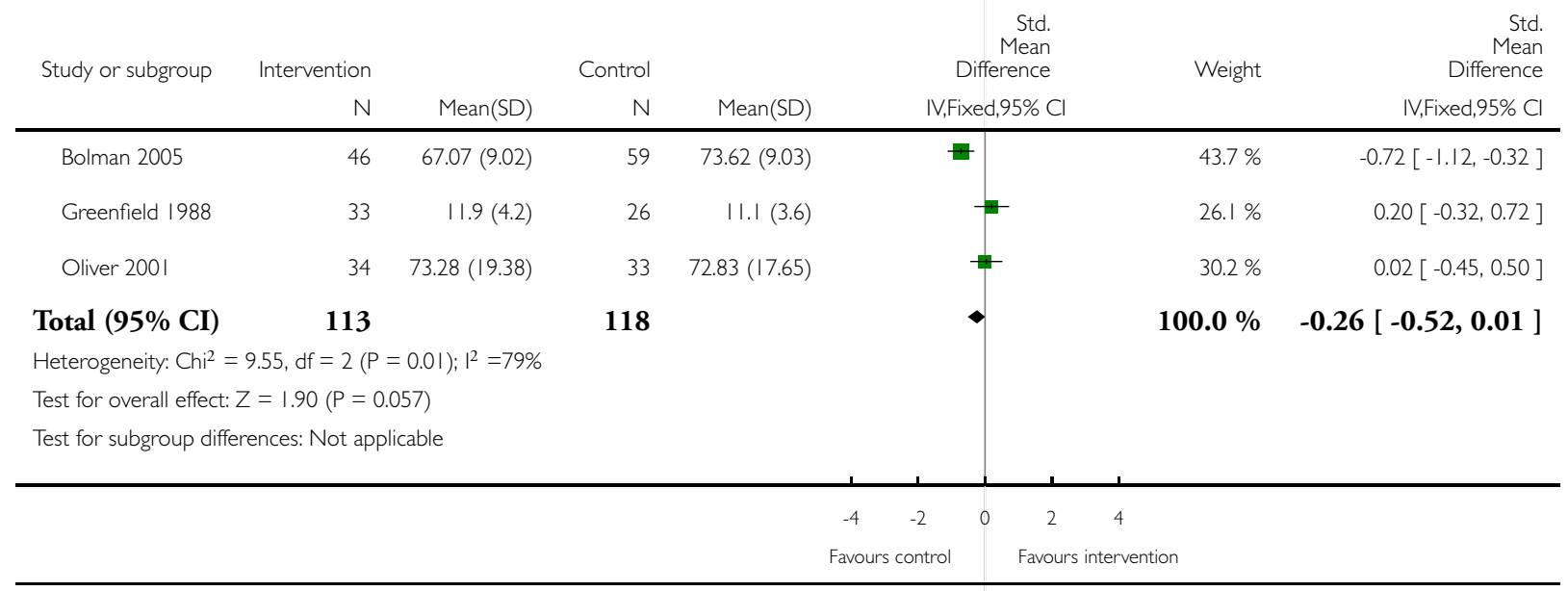




\section{Analysis I.7. Comparison I Intervention versus control, Outcome 7 Consultation length.}

Review: Interventions before consultations for helping patients address their information needs

Comparison: I Intervention versus control

Outcome: 7 Consultation length

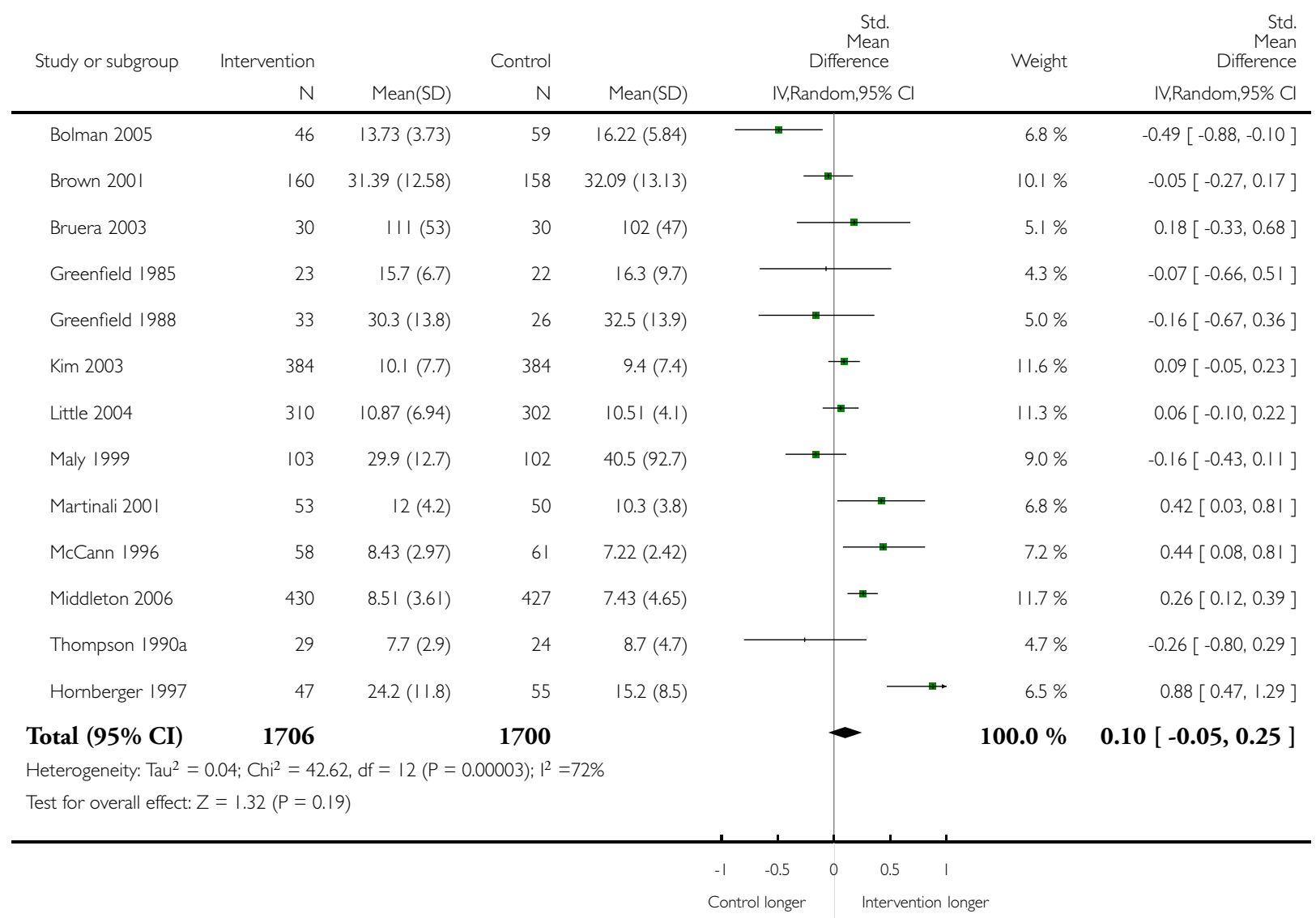




\section{Analysis 2.I. Comparison 2 Written materials and coaching, Outcome I Question asking.}

Review: Interventions before consultations for helping patients address their information needs

Comparison: 2 Written materials and coaching

Outcome: | Question asking

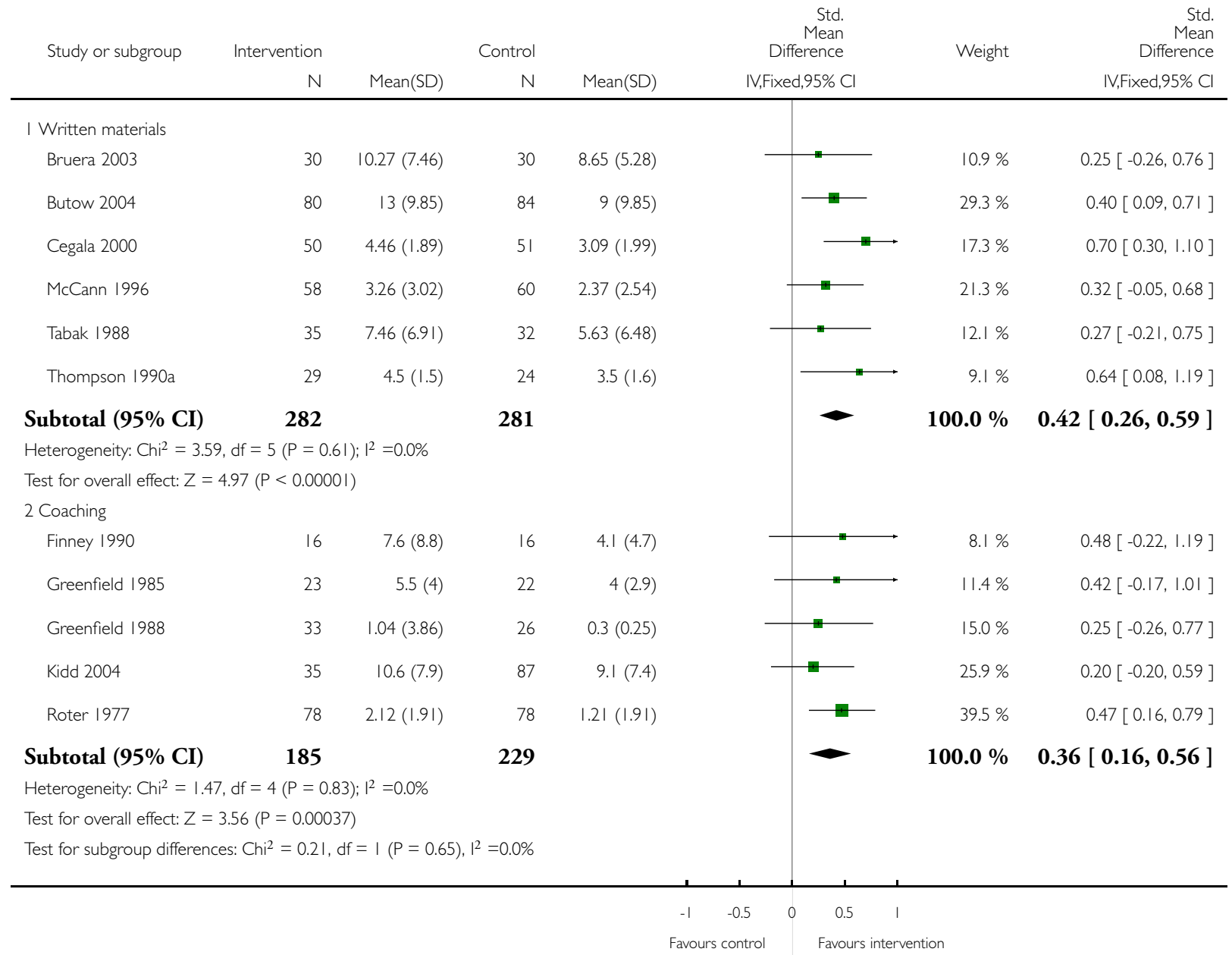




\section{Analysis 2.2. Comparison 2 Written materials and coaching, Outcome 2 Satisfaction.}

Review: Interventions before consultations for helping patients address their information needs

Comparison: 2 Written materials and coaching

Outcome: 2 Satisfaction

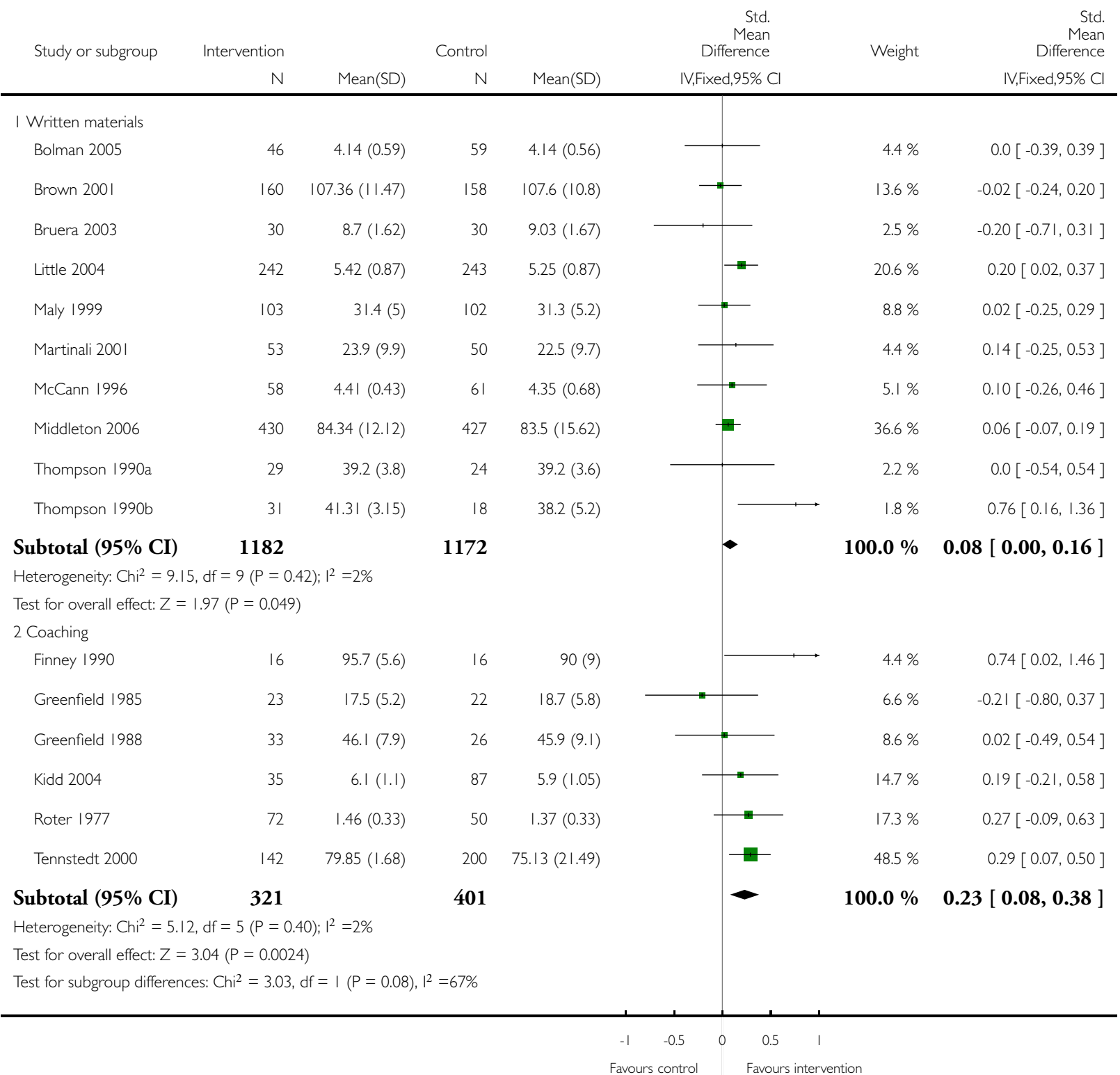




\section{Analysis 2.3. Comparison 2 Written materials and coaching, Outcome 3 Consultation length.}

Review: Interventions before consultations for helping patients address their information needs

Comparison: 2 Written materials and coaching

Outcome: 3 Consultation length

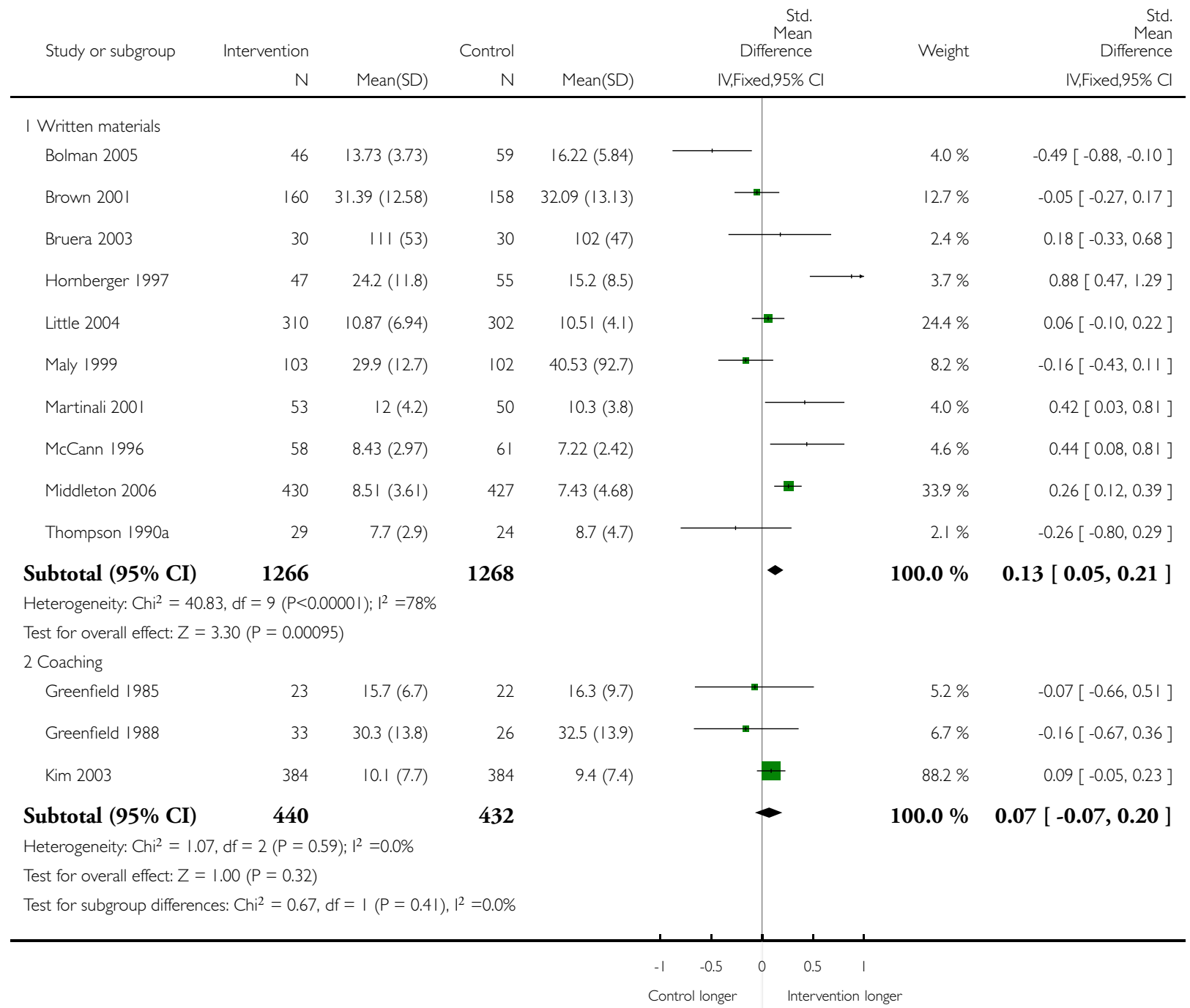




\section{Analysis 3.I. Comparison 3 Timing, Outcome I Satisfaction.}

Review: Interventions before consultations for helping patients address their information needs

Comparison: 3 Timing

Outcome: | Satisfaction

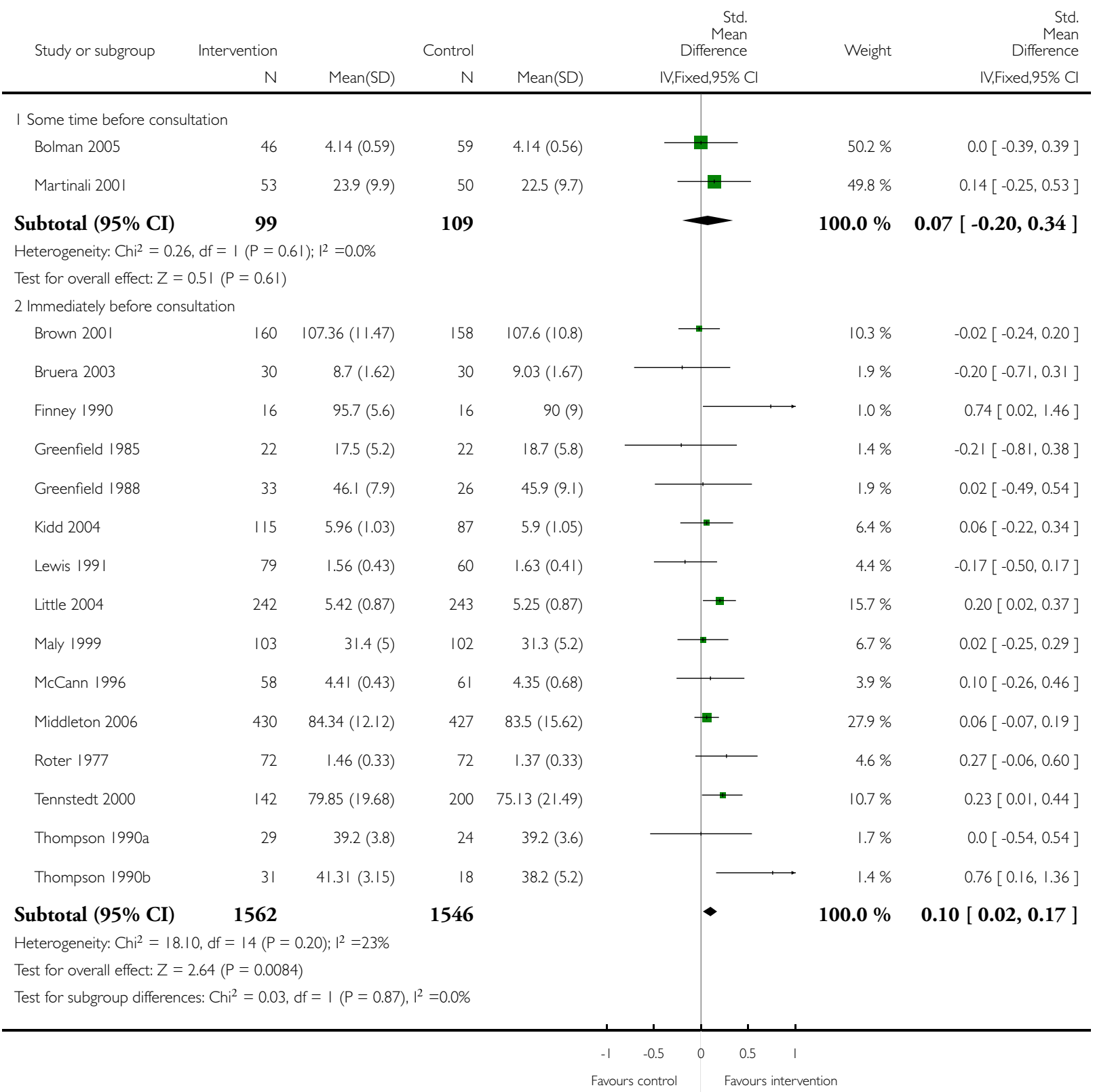




\section{Analysis 3.2. Comparison 3 Timing, Outcome 2 Consultation length.}

Review: Interventions before consultations for helping patients address their information needs

Comparison: 3 Timing

Outcome: 2 Consultation length

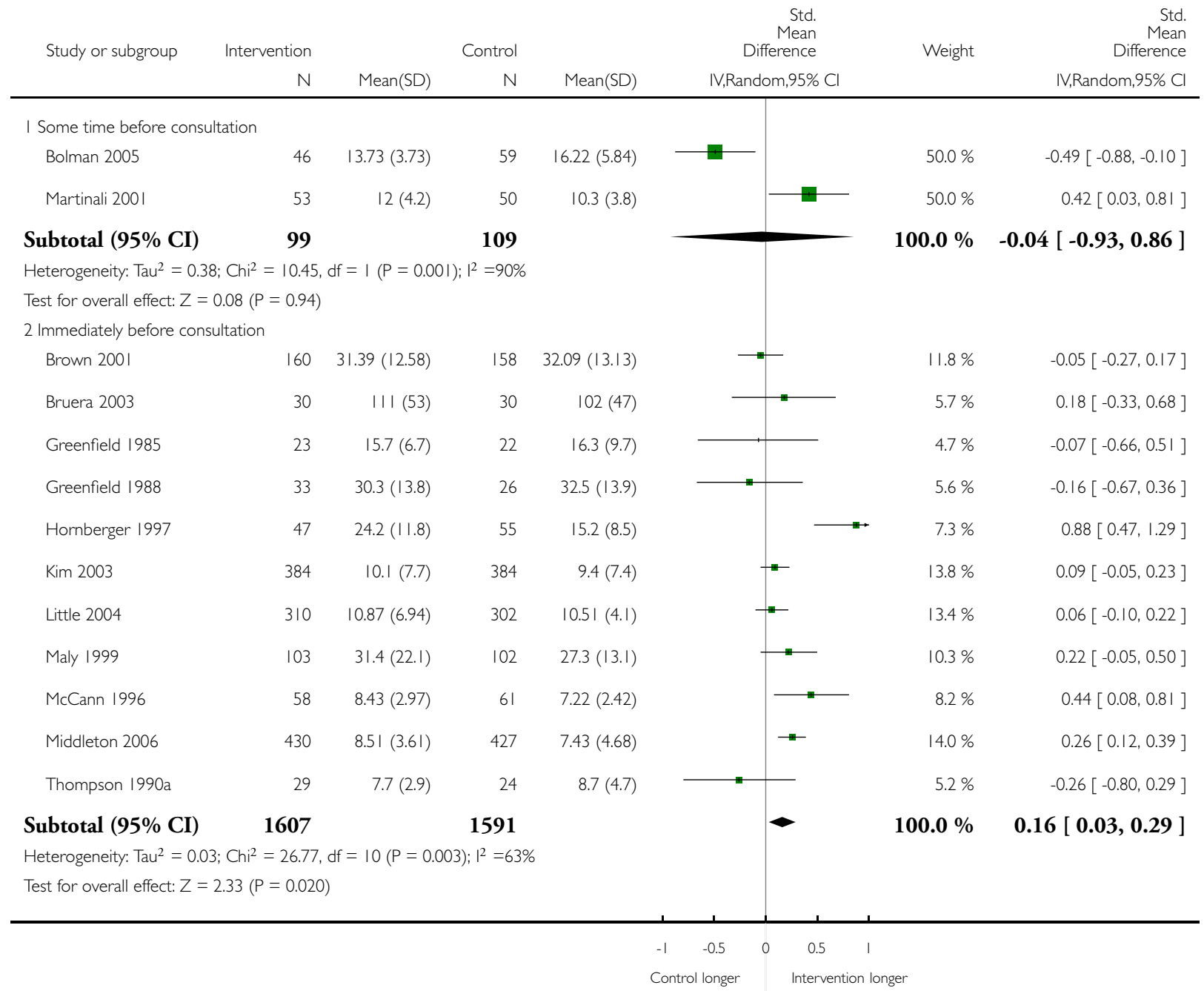




\section{Analysis 4.I. Comparison 4 Clinician training, Outcome I Satisfaction.}

Review: Interventions before consultations for helping patients address their information needs

Comparison: 4 Clinician training

Outcome: | Satisfaction

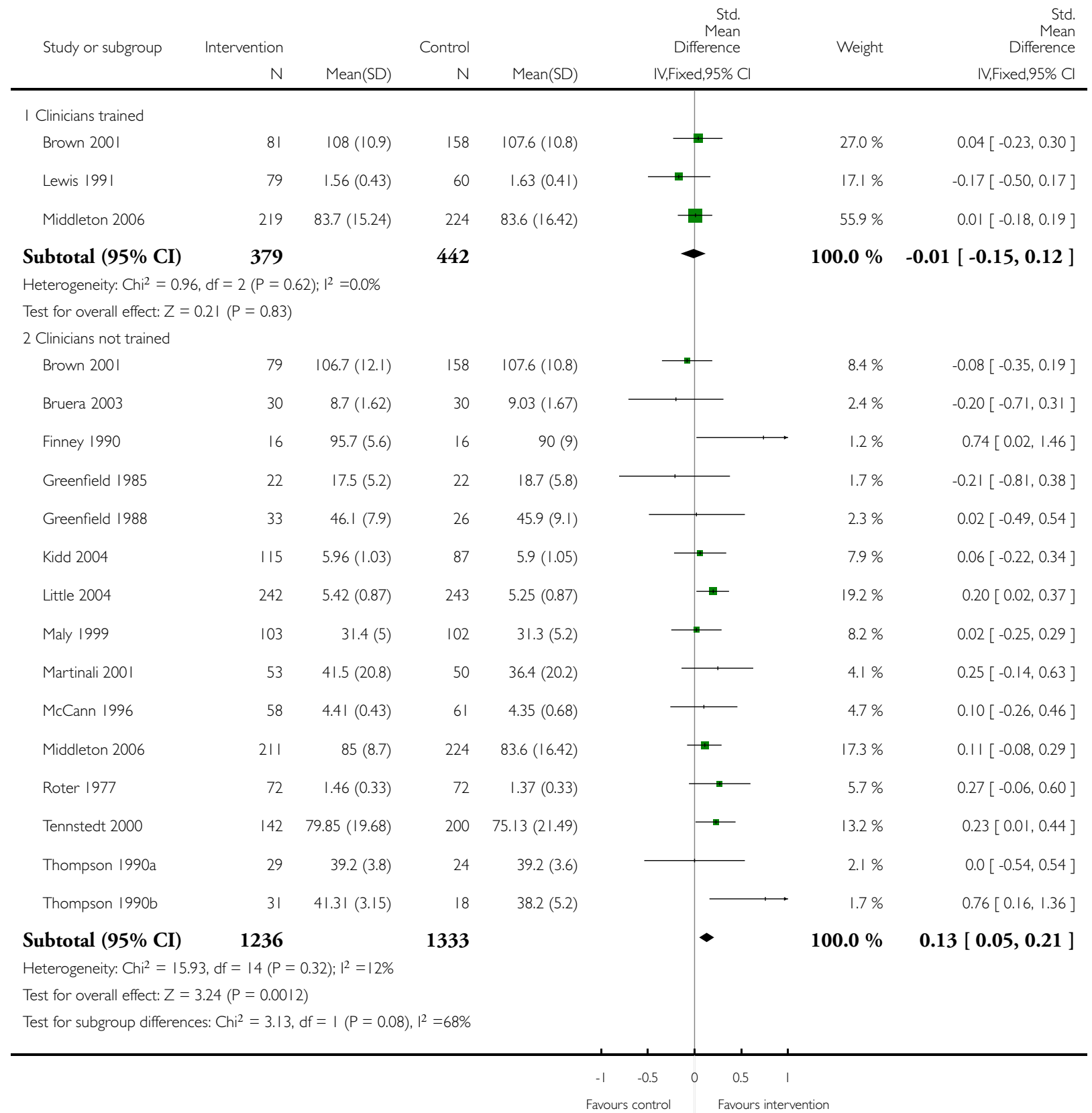




\section{Analysis 4.2. Comparison 4 Clinician training, Outcome 2 Consultation length.}

Review: Interventions before consultations for helping patients address their information needs

Comparison: 4 Clinician training

Outcome: 2 Consultation length

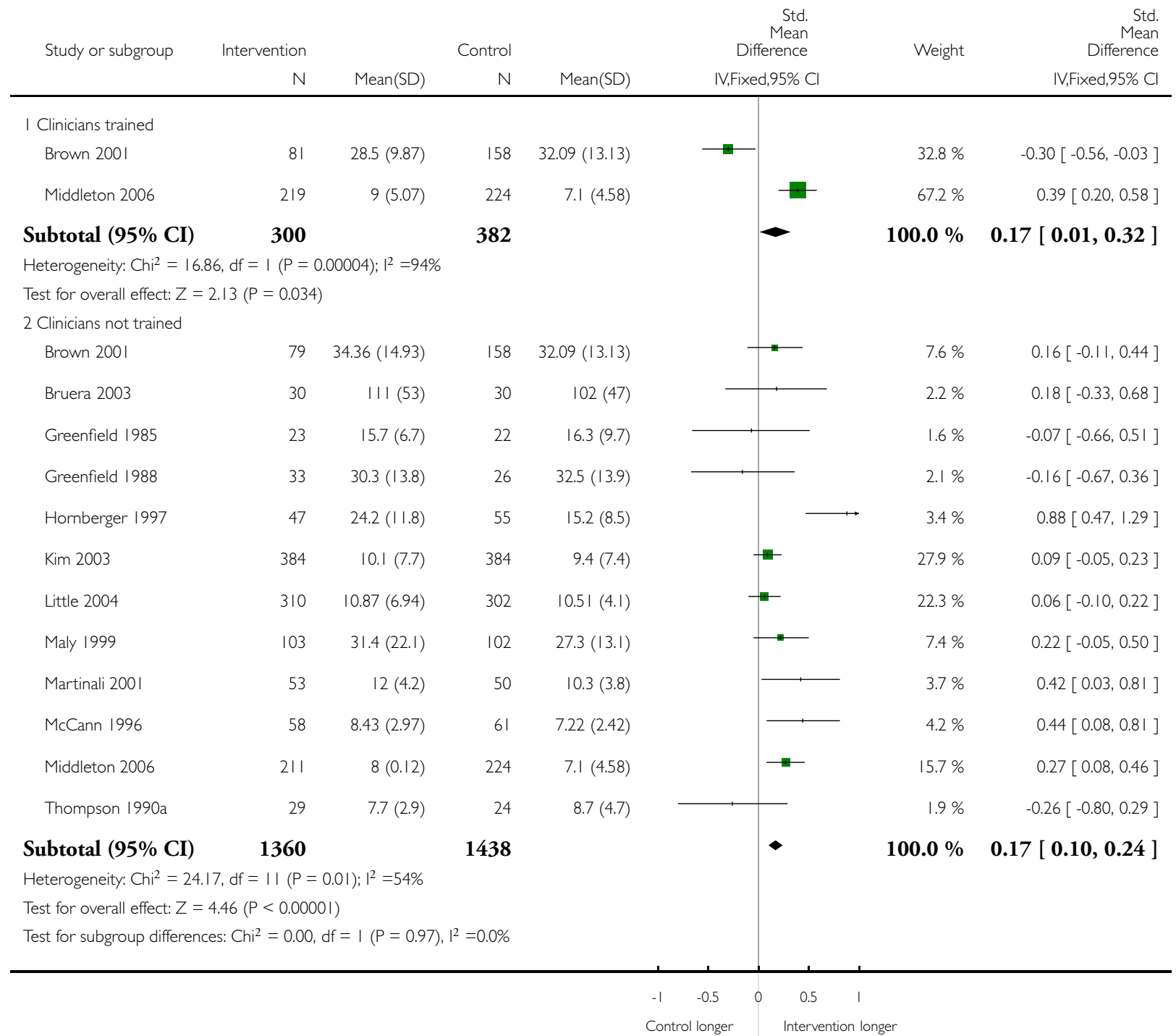


ADDITIONAL TABLES

Table 1. Details of interventions

\begin{tabular}{|c|c|c|}
\hline Study name & Setting & Intervention \\
\hline & & $\begin{array}{l}\text { IMMEDIATELY BEFORE CONSULTATION (WHILE PA- } \\
\text { TIENT WAITING TO SEE CLINICIAN) }\end{array}$ \\
\hline & & - Written materials \\
\hline Brown 2001 & Oncology clinics, Australia & $\begin{array}{l}\text { Question checklist endorsing question asking as a useful activity and } \\
\text { welcomed by the doctor. Contained checklist of questions and par- } \\
\text { ticipants circled questions they wanted to ask. Clinicians actively en- } \\
\text { dorsed the checklist for a sample of patients }\end{array}$ \\
\hline Bruera 2003 & Oncology clinic, USA & $\begin{array}{l}\text { Question checklist containing } 22 \text { questions with space for additional } \\
\text { questions }\end{array}$ \\
\hline Butow 1994 & Oncology clinic, Australia & $\begin{array}{l}\text { Question checklist designed to encourage question asking in the con- } \\
\text { sultation }\end{array}$ \\
\hline Frederickson 1995 & General practice, UK & $\begin{array}{l}\text { Leaflet (single page) encouraging patients to 'stop, think and tell the } \\
\text { doctor about their problems and worries' }\end{array}$ \\
\hline Hornberger 1997 & Primary care clinics, USA & $\begin{array}{l}\text { Question checklist with } 25 \text { items covering five categories of concerns. } \\
\text { Patients marked whether they wanted to discuss the concern then } \\
\text { identified three main concerns. List attached to medical records so } \\
\text { physician could address during consultation }\end{array}$ \\
\hline Little 2004 & General practices, UK & $\begin{array}{l}\text { Leaflet asking patients to list issues they wanted to raise and explaining } \\
\text { that the doctor wanted them to be able to ask questions }\end{array}$ \\
\hline Maly 1999 & Family medicine clinic, USA & $\begin{array}{l}\text { Question checklist in which patients asked to record two main ques- } \\
\text { tions they wanted to ask. Also given copy of previous entry in medical } \\
\text { records }\end{array}$ \\
\hline McCann 1996 & General practice, UK & $\begin{array}{l}\text { Question checklist ('Speak for yourself' leaflet) with space to write } \\
\text { down ideas and encouraging patients to ask questions }\end{array}$ \\
\hline Middleton 2006 & General practices, UK & Patient agenda form asking patients to identify questions. \\
\hline Sander 1996a & Family medicine clinic, USA & $\begin{array}{l}\text { Two intervention groups - each given different versions of 'health con- } \\
\text { cerns card' focusing on health maintenance and designed to stimulate } \\
\text { patient information seeking }\end{array}$ \\
\hline Tabak 1988 & Family medicine clinic, USA & $\begin{array}{l}\text { Question checklist designed to encourage question asking in the con- } \\
\text { sultation }\end{array}$ \\
\hline
\end{tabular}

Thompson 1990a Obstetric and gynaecology clinic, USA Question checklist with list of possible concerns and instructions to write down at least three questions 


\begin{tabular}{|c|c|c|}
\hline Thompson 1990b & Obstetric and gynaecology clinic, USA & $\begin{array}{l}\text { Two intervention groups - Group 1: Question checklist with list of } \\
\text { possible concerns and instructions to write down at least three ques- } \\
\text { tions. Group 2: Written message from physician encouraging patients } \\
\text { to ask questions but not write them down }\end{array}$ \\
\hline & & - Coaching \\
\hline Finney 1990 & Well baby clinics, USA & $\begin{array}{l}\text { 'Brief prompting strategy' to help patients identify questions of inter- } \\
\text { est to them }\end{array}$ \\
\hline Greenfield 1985 & Outpatient clinic, USA & $\begin{array}{l}\text { Twenty minutes with three components: a) review of records, b) re- } \\
\text { view of a treatment algorithm, c) behaviour change strategy to in- } \\
\text { crease involvement in consultation }\end{array}$ \\
\hline Greenfield 1988 & Diabetic clinic, USA & $\begin{array}{l}\text { As in Greenfield } 1985 \text { but delivered twice, before initial and follow } \\
\text { up consultations (before outcomes measured) to increase the involve- } \\
\text { ment of patients in medical decision making and to improve patient } \\
\text { information seeking }\end{array}$ \\
\hline
\end{tabular}

\begin{tabular}{|c|c|c|}
\hline Roter 1977 & Family medicine clinic, USA & $\begin{array}{l}\text { Ten minutes with health educator working through a question ask- } \\
\text { ing protocol to identify and write down patients' questions. Also en- } \\
\text { couragement to ask questions and patients took list of questions into } \\
\text { consultation }\end{array}$ \\
\hline
\end{tabular}

\begin{tabular}{|c|c|c|}
\hline Sander $1996 \mathrm{~b}$ & Family medicine clinic, USA & $\begin{array}{l}\text { Two intervention groups - each given different versions of } 5 \text { minutes } \\
\text { of coaching with encouragement to identify and/or write down ques- } \\
\text { tions }\end{array}$ \\
\hline
\end{tabular}

- Combined interventions

-- Written materials and coaching

Brown $1999 \quad$ Oncology clinic, Australia

Two intervention groups - Group 1: Question checklist containing 17 questions. Group 2: Question checklist with brief coaching from research psychologist covering question generation, exploration of benefits of and barriers to asking questions and rehearsal. Clinicians 'endorsed' the checklist and elicited and answered questions according to a standard protocol

Davison 1997 Oncology clinic, Canada

Combined intervention - Question checklist completed by patient and then reviewed with researcher who provided coaching using an information pack to identify additional questions to ask. Patients encouraged to ask questions and ask for audiotape of consultation 


\begin{tabular}{|c|c|c|}
\hline Kidd 2004 & Diabetic clinic, UK & $\begin{array}{l}\text { Three intervention groups - Group 1: Written message encouraging } \\
\text { patients to ask questions. Group 2: Coaching for five minutes with } \\
\text { researcher including identifying at least three questions to ask. Group } \\
\text { 3: Coaching and rehearsal: five minutes with researcher identifying at } \\
\text { least three questions to ask and also rehearsal of asking }\end{array}$ \\
\hline Kim 2003 & Family planning clinics, Indonesia & $\begin{array}{l}\text { Combined intervention - Question checklist completed by patient } \\
\text { and 'Smart patient' coaching including how to ask questions and } \\
\text { identification of questions to ask }\end{array}$ \\
\hline \multirow[t]{2}{*}{ Oliver 2001} & Oncology clinics, USA & $\begin{array}{l}\text { Combined intervention - Question checklist in form of booklet en- } \\
\text { couraging question asking with space to write down questions com- } \\
\text { bined with coaching: to teach patients practical pain management } \\
\text { techniques and to empower patients to participate actively in their } \\
\text { own care }\end{array}$ \\
\hline & & -- Computer and coaching \\
\hline \multirow[t]{2}{*}{ Davison 2002} & Oncology clinic, Canada & $\begin{array}{l}\text { Combined intervention - Computer programme to identify control } \\
\text { preferences and information needs followed by coaching from nurses } \\
\text { as to how to use computer printouts in the consultation to gather } \\
\text { information }\end{array}$ \\
\hline & & -- Video and coaching \\
\hline Lewis 1991 & Paediatric clinic, USA & $\begin{array}{l}\text { Combined intervention - three facets: Children shown } 10 \text { minute } \\
\text { video with workbook to write down questions then coached to prac- } \\
\text { tice questions with research assistant. Parents shown } 10 \text { minute video. } \\
\text { Physicians shown } 15 \text { minute video as part of one hour training session } \\
\text { with boosters at } 3,8 \text { and } 15 \text { months. Four common themes to videos } \\
\text { - 1) opportunity to think about the goals of the medical visit; 2) the } \\
\text { long term goal of medical care is to encourage the child to be an active } \\
\text { participant in the consultation; } 3 \text { ) modelling of skills to achieve this; } \\
\text { 4) provision of evidence to support this }\end{array}$ \\
\hline
\end{tabular}

SOME TIME BEFORE THE DAY OF THE CONSULTATION

- Written materials

Bolman 2005 Cardiology clinics, The Netherlands Question checklist containing 49 questions on 10 different issues (as Martinali 2001). Mailed to patient one week before each of three linked consultations

Butow $2004 \quad$ Oncology clinic, Australia

Question checklist - 'Cancer consultation package' with three components: 1) 'How treatment decisions are made' booklet describing principles of evidence-based medicine; 2) 'Your rights and responsibilities as a patient' brochure describing patients' legal rights; 3) ques- 


\begin{tabular}{|c|c|c|}
\hline & & $\begin{array}{l}\text { tion prompt sheet endorsing question asking with } 19 \text { suggested ques- } \\
\text { tions and recommendation to prepare list of questions (as in Butow } \\
1994 \text {, Brown 1999, Brown 2001). Mailed to patients at least } 2 \text { days } \\
\text { before consultation }\end{array}$ \\
\hline Fleissig 1999 & Outpatient clinic, UK & $\begin{array}{l}\text { Question checklist in form of 'help card' and letter. The help card } \\
\text { suggested general questions with space for the patient to write down } \\
\text { questions covering the patient's condition, tests, treatment and other } \\
\text { concerns. Mailed to patients two weeks before hospital visit }\end{array}$ \\
\hline Martinali 2001 & Cardiology clinics, The Netherlands & $\begin{array}{l}\text { Question checklist with } 49 \text { items 'frequently asked questions' on } 10 \\
\text { different issues. Also information booklet about heart disease. Mailed } \\
\text { to patients one week before consultation }\end{array}$ \\
\hline Wilkinson 2002 & Family medicine clinics, USA & $\begin{array}{l}\text { Question checklist in format of guidebook 'How to be prepared' } \\
\text { with aim of improving patients' perceptions of primary care visit } \\
\text { effectiveness with space for patient to write down questions. Mailed } \\
\text { to patient prior to visit }\end{array}$ \\
\hline
\end{tabular}

\begin{tabular}{|c|c|c|}
\hline & & - Combined interventions \\
\hline & & -- Written materials and coaching \\
\hline \multirow[t]{2}{*}{ Tennstedt 2000} & Family medicine clinic, USA & $\begin{array}{l}\text { Combined intervention - Question checklist in format of booklet for } \\
\text { patient to record and prioritise reasons for visit and to record questions } \\
\text { to ask. Coaching: two hour group programme including modelling } \\
\text { of both desirable and undesirable behaviours. Up to three months } \\
\text { before consultation }\end{array}$ \\
\hline & & -- Written materials and information \\
\hline Cegala 2000 & Primary care clinics, USA & $\begin{array}{l}\text { Two intervention groups - Group 1: Question checklist in format of } \\
14 \text { page workbook encouraging patients to list topics they wanted to } \\
\text { discuss with additional sections on information seeking and verify- } \\
\text { ing. All sections contained example questions. Mailed to patients } 2 \text { to } \\
4 \text { days before consultation and briefly gone over on arrival at clinic. } \\
\text { Group 2: Brief summary of points in training booklet and patients } \\
\text { encouraged verbally to organise thoughts and ask questions. On ar- } \\
\text { rival at clinic }\end{array}$ \\
\hline
\end{tabular}

\section{AUDIOTAPE OF PREVIOUS CONSULTATION}

Ford $1995 \quad$ Oncology clinic, UK

Audiotape of initial consultation, patient encouraged to listen to it at home before second consultation which was a month later 
Table 2. Main outcomes for each study

\begin{tabular}{|c|c|c|c|c|c|c|c|c|}
\hline Study name & $\begin{array}{l}\text { Interven- } \\
\text { tion }\end{array}$ & $\begin{array}{l}\text { Numbers } \\
\text { randomised }\end{array}$ & $\begin{array}{l}\text { Question } \\
\text { asking }\end{array}$ & Anxiety & $\begin{array}{l}\text { Patient sat- } \\
\text { isfaction }\end{array}$ & Knowledge & $\begin{array}{l}\text { Consulta- } \\
\text { tion length }\end{array}$ & $\begin{array}{l}\text { Other out- } \\
\text { comes }\end{array}$ \\
\hline $\begin{array}{l}\text { Bolman } \\
2005\end{array}$ & $\begin{array}{l}\text { Ques- } \\
\text { tion check- } \\
\text { list - before } \\
\text { each of three } \\
\text { visits }\end{array}$ & 153 & & $\begin{array}{l}\text { Reduced } \\
\text { (before first } \\
\text { visit) }\end{array}$ & No change & $\begin{array}{l}\text { Reduced } \\
\text { (be- } \\
\text { fore first and } \\
\text { third visits) }\end{array}$ & $\begin{array}{l}\text { Reduced } \\
\text { (first visit), } \\
\text { increased } \\
\text { (third visit) }\end{array}$ & 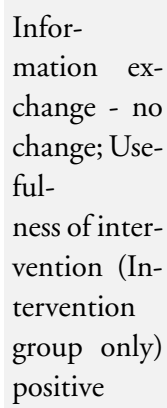 \\
\hline Brown 1999 & $\begin{array}{l}\text { Ques- } \\
\text { tion check- } \\
\text { list; coach- } \\
\text { ing }\end{array}$ & 60 & Increased & No change & No change & & & $\begin{array}{l}\text { Psycholog- } \\
\text { ical adjust- } \\
\text { ment } \\
\text { no change; } \\
\text { Types } \\
\text { of question } \\
\text { asked about } \\
\text { prognosis } \\
\text { increased }\end{array}$ \\
\hline Brown 2001 & $\begin{array}{l}\text { Ques- } \\
\text { tion check- } \\
\text { list; doctor } \\
\text { training }\end{array}$ & 318 & No change & Increased & No change & & No change & $\begin{array}{l}\text { Recall } \\
\text { no change; } \\
\text { Types } \\
\text { of question } \\
\text { asked about } \\
\text { prognosis } \\
\text { increased }\end{array}$ \\
\hline Bruera 2003 & $\begin{array}{l}\text { Question } \\
\text { checklist }\end{array}$ & 60 & No change & & No change & & No change & $\begin{array}{l}\text { Clinician } \\
\text { satisfaction } \\
\text { no change; } \\
\text { Types } \\
\text { of questions } \\
\text { asked } \\
\text { no change; } \\
\text { Helpfulness } \\
\text { of interven- } \\
\text { tions (both } \\
\text { groups) in- } \\
\text { creased; Sat- } \\
\text { is- } \\
\text { faction with } \\
\text { commu- } \\
\text { nication no }\end{array}$ \\
\hline
\end{tabular}


Table 2. Main outcomes for each study (Continued)

\begin{tabular}{|c|c|c|c|c|c|c|c|}
\hline & & & & & & & $\begin{array}{l}\text { change; } \\
\text { Clinician es- } \\
\text { timate } \\
\text { of consulta- } \\
\text { tion length } \\
\text { no change }\end{array}$ \\
\hline Butow 1994 & $\begin{array}{l}\text { Question } \\
\text { checklist }\end{array}$ & 142 & No change & & No change & No change & $\begin{array}{l}\text { Psycholog- } \\
\text { ical adjust- } \\
\text { ment } \\
\text { no change; } \\
\text { Types } \\
\text { of question } \\
\text { asked about } \\
\text { progno- } \\
\text { sis increased; } \\
\text { Recall no } \\
\text { change }\end{array}$ \\
\hline Butow 2004 & $\begin{array}{l}\text { Question } \\
\text { checklist }\end{array}$ & 164 & Increased & $\begin{array}{l}\text { In- } \\
\text { creased (Be- } \\
\text { fore consul- } \\
\text { tations); No } \\
\text { change (af- } \\
\text { ter consulta- } \\
\text { tion and at } 1 \\
\text { month) }\end{array}$ & $\begin{array}{l}\text { No change } \\
\text { (immedi- } \\
\text { ately and at } \\
1 \text { month) }\end{array}$ & No change & $\begin{array}{l}\text { Participa- } \\
\text { tion } \\
\text { increased; } \\
\text { Useful- } \\
\text { ness of inter- } \\
\text { vention pos- } \\
\text { itive; De- } \\
\text { pression (be- } \\
\text { fore and af- } \\
\text { ter consulta- } \\
\text { tion) no } \\
\text { change; In- } \\
\text { volve- } \\
\text { ment in de- } \\
\text { cision mak- } \\
\text { ing no } \\
\text { change; Sat- } \\
\text { is- } \\
\text { faction with } \\
\text { treatment } \\
\text { decision no } \\
\text { change }\end{array}$ \\
\hline Cegala 2000 & $\begin{array}{l}\text { Ques- } \\
\text { tion check- } \\
\text { list; brief in- } \\
\text { for- } \\
\text { mation and } \\
\text { coaching }\end{array}$ & 150 & $\begin{array}{l}\text { Increased } \\
\text { (Checklist } \\
\text { only) }\end{array}$ & & & & $\begin{array}{l}\text { Participa- } \\
\text { tion } \\
\text { increased; } \\
\text { Compliance } \\
\text { increased }\end{array}$ \\
\hline
\end{tabular}


Table 2. Main outcomes for each study (Continued)

\begin{tabular}{|c|c|c|c|c|c|c|c|c|}
\hline $\begin{array}{l}\text { Davison } \\
1997\end{array}$ & $\begin{array}{l}\text { Ques- } \\
\text { tion check- } \\
\text { list and } \\
\text { coaching }\end{array}$ & 60 & & No change & & & & $\begin{array}{l}\text { Depression } \\
\text { no change; } \\
\text { Preferences } \\
\text { for } \\
\text { control over } \\
\text { treatment } \\
\text { decisions in- } \\
\text { creased }\end{array}$ \\
\hline $\begin{array}{l}\text { Davison } \\
2002\end{array}$ & $\begin{array}{l}\text { Computer } \\
\text { pro- } \\
\text { gramme and } \\
\text { coaching }\end{array}$ & 749 & & & No change & & & $\begin{array}{l}\text { Role prefer- } \\
\text { ences no } \\
\text { change }\end{array}$ \\
\hline Finney 1990 & Coaching & 32 & No change & & No change & & & \\
\hline $\begin{array}{l}\text { Fleissig } \\
1999\end{array}$ & $\begin{array}{l}\text { Question } \\
\text { checklist }\end{array}$ & 1208 & & & Increased & & & $\begin{array}{l}\text { Participa- } \\
\text { tion in- } \\
\text { creased; Pre- } \\
\text { pared ques- } \\
\text { tions raised } \\
\text { no change }\end{array}$ \\
\hline Ford 1995 & $\begin{array}{l}\text { Audiotape } \\
\text { of previous } \\
\text { consultation }\end{array}$ & 117 & No change & $\begin{array}{l}\text { No change } \\
\text { (before con- } \\
\text { sultation) }\end{array}$ & & & No change & $\begin{array}{l}\text { Participa- } \\
\text { tion in- } \\
\text { creased; De- } \\
\text { pression no } \\
\text { change (be- } \\
\text { fore consul- } \\
\text { tation) }\end{array}$ \\
\hline $\begin{array}{l}\text { Frederick- } \\
\text { son } 1995\end{array}$ & $\begin{array}{l}\text { Question } \\
\text { checklist }\end{array}$ & 80 & & & & & & $\begin{array}{l}\text { Doctor's as- } \\
\text { sessment of } \\
\text { qual- } \\
\text { ity of con- } \\
\text { sultation in- } \\
\text { creased }\end{array}$ \\
\hline $\begin{array}{l}\text { Greenfield } \\
1985\end{array}$ & Coaching & 45 & No change & & No change & Reduced & No change & $\begin{array}{l}\text { Participa- } \\
\text { tion } \\
\text { increased; } \\
\text { Role and } \\
\text { physical lim- } \\
\text { itation re- } \\
\text { duced; Pain } \\
\text { no change; } \\
\text { Preference } \\
\text { for active in- }\end{array}$ \\
\hline
\end{tabular}


Table 2. Main outcomes for each study (Continued)

\begin{tabular}{|c|c|c|c|c|c|c|c|c|}
\hline & & & & & & & & $\begin{array}{l}\text { volvement } \\
\text { increased }\end{array}$ \\
\hline $\begin{array}{l}\text { Greenfield } \\
1988\end{array}$ & $\begin{array}{l}\text { Coaching } \\
\text { (delivered } \\
\text { twice) }\end{array}$ & 73 & No change & & No change & No change & No change & $\begin{array}{l}\text { Partic- } \\
\text { ipation } \\
\text { increased; } \\
\text { Functional } \\
\text { limitations } \\
\text { reduced; } \\
\text { Health } \\
\text { status in- } \\
\text { creased; } \\
\text { Days lost } \\
\text { from work } \\
\text { reduced; } \\
\text { HbA1c } \\
\text { reduced }\end{array}$ \\
\hline $\begin{array}{l}\text { Hornberger } \\
1997\end{array}$ & $\begin{array}{l}\text { Question } \\
\text { checklist }\end{array}$ & 101 & & Reduced & No change & & Increased & $\begin{array}{l}\text { Depression } \\
\text { no change; } \\
\text { Health sta- } \\
\text { tus } \\
\text { no change; } \\
\text { Services pro- } \\
\text { vided } \\
\text { no change; } \\
\text { Clinician } \\
\text { satisfaction } \\
\text { no change }\end{array}$ \\
\hline Kidd 2004 & $\begin{array}{l}\text { Writ- } \\
\text { ten message; } \\
\text { coach- } \\
\text { ing; coach- } \\
\text { ing and re- } \\
\text { hearsal }\end{array}$ & 202 & No change & & $\begin{array}{l}\text { No change } \\
\text { (imme- } \\
\text { diately); in- } \\
\text { creased } \\
\text { (three } \\
\text { months) }\end{array}$ & & & $\begin{array}{l}\text { Patient self } \\
\text { efficacy in- } \\
\text { creased; } \\
\text { HbAlc no } \\
\text { change }\end{array}$ \\
\hline Kim 2003 & $\begin{array}{l}\text { Ques- } \\
\text { tion check- } \\
\text { list and } \\
\text { coaching }\end{array}$ & 768 & Increased & & & & No change & $\begin{array}{l}\text { Participa- } \\
\text { tion in- } \\
\text { creased; Pa- } \\
\text { tient assess- } \\
\text { ment } \\
\text { of commu- } \\
\text { nication no } \\
\text { change; Dis- } \\
\text { continu- } \\
\text { ation of con- } \\
\text { traception } \\
\text { no change }\end{array}$ \\
\hline
\end{tabular}


Table 2. Main outcomes for each study (Continued)

\begin{tabular}{|c|c|c|c|c|c|c|}
\hline Lewis 1991 & $\begin{array}{l}\text { Videotape } \\
\text { for child, } \\
\text { parent and } \\
\text { clinician }\end{array}$ & 141 & $\begin{array}{l}\text { Child anxi- } \\
\text { ety no } \\
\text { change }\end{array}$ & $\begin{array}{l}\text { Child sat- } \\
\text { isfaction in- } \\
\text { creased; par- } \\
\text { ent sat- } \\
\text { isfaction no } \\
\text { change }\end{array}$ & & $\begin{array}{l}\text { Partic- } \\
\text { ipation } \\
\text { increased; } \\
\text { General } \\
\text { recall no } \\
\text { change; } \\
\text { Medica- } \\
\text { tion recall } \\
\text { increased; } \\
\text { Child } \\
\text { preference } \\
\text { for active } \\
\text { health role } \\
\text { increased; } \\
\text { Physician } \\
\text { satisfaction } \\
\text { no change }\end{array}$ \\
\hline Little 2004 & $\begin{array}{l}\text { Question } \\
\text { checklist }\end{array}$ & 636 & No change & Increased & No change & $\begin{array}{l}\text { De- } \\
\text { pression no } \\
\text { change; En- } \\
\text { ablement no } \\
\text { change; Res- } \\
\text { olution of } \\
\text { symptoms } \\
\text { no change; } \\
\text { Num- } \\
\text { ber of inves- } \\
\text { tigations in- } \\
\text { creased }\end{array}$ \\
\hline Maly 1999 & $\begin{array}{l}\text { Ques- } \\
\text { tion check- } \\
\text { list (deliv- } \\
\text { ered twice) }\end{array}$ & 265 & & Increased & No change & $\begin{array}{l}\text { Phys- } \\
\text { ical function } \\
\text { increased; } \\
\text { Global } \\
\text { health no } \\
\text { change; Dis- } \\
\text { abil- } \\
\text { ity days no } \\
\text { change; Ad- } \\
\text { herence no } \\
\text { change; De- } \\
\text { sire } \\
\text { to see med- } \\
\text { ical records } \\
\text { no change; } \\
\text { Propensity }\end{array}$ \\
\hline
\end{tabular}


Table 2. Main outcomes for each study (Continued)

\begin{tabular}{|c|c|c|c|c|c|c|c|c|}
\hline & & & & & & & & $\begin{array}{l}\text { for medical } \\
\text { information } \\
\text { increased }\end{array}$ \\
\hline $\begin{array}{l}\text { Martinali } \\
2001\end{array}$ & $\begin{array}{l}\text { Question } \\
\text { checklist }\end{array}$ & 142 & & $\begin{array}{l}\text { Reduced } \\
\text { (before con- } \\
\text { sultation) }\end{array}$ & No change & No change & No change & $\begin{array}{l}\text { Participa- } \\
\text { tion no } \\
\text { change; Ad- } \\
\text { equacy of in- } \\
\text { formation } \\
\text { exchange no } \\
\text { change }\end{array}$ \\
\hline $\begin{array}{l}\text { McCann } \\
1996\end{array}$ & $\begin{array}{l}\text { Question } \\
\text { checklist }\end{array}$ & 120 & No change & & No change & & Increased & $\begin{array}{l}\text { Phys- } \\
\text { ical function } \\
\text { no change; } \\
\text { Men- } \\
\text { tal health no } \\
\text { change; } \\
\text { Clinician } \\
\text { evaluation } \\
\text { no change; } \\
\text { Consulta- } \\
\text { tions in next } \\
12 \text { months } \\
\text { no change }\end{array}$ \\
\hline $\begin{array}{l}\text { Middleton } \\
2006\end{array}$ & $\begin{array}{l}\text { Ques- } \\
\text { tion prompt } \\
\text { sheet }\end{array}$ & 955 & & & $\begin{array}{l}\text { No change } \\
\text { except } \\
\text { for depth of } \\
\text { doctor- } \\
\text { patient rela- } \\
\text { tionship (in- } \\
\text { creased) }\end{array}$ & & Increased & \\
\hline Oliver 2001 & $\begin{array}{l}\text { Ques- } \\
\text { tion check- } \\
\text { list and } \\
\text { coaching }\end{array}$ & 87 & & No change & & No change & & $\begin{array}{l}\text { Pain re- } \\
\text { duced; Pain- } \\
\text { related im- } \\
\text { pairment no } \\
\text { change; Pain } \\
\text { frequency } \\
\text { no change; } \\
\text { Analgesic } \\
\text { adherence } \\
\text { no change }\end{array}$ \\
\hline Roter 1977 & Coaching & 200 & Increased & & Increased & & No change & $\begin{array}{l}\text { Participa- } \\
\text { tion no } \\
\text { change; Pa- } \\
\text { tient expres- }\end{array}$ \\
\hline
\end{tabular}


Table 2. Main outcomes for each study (Continued)

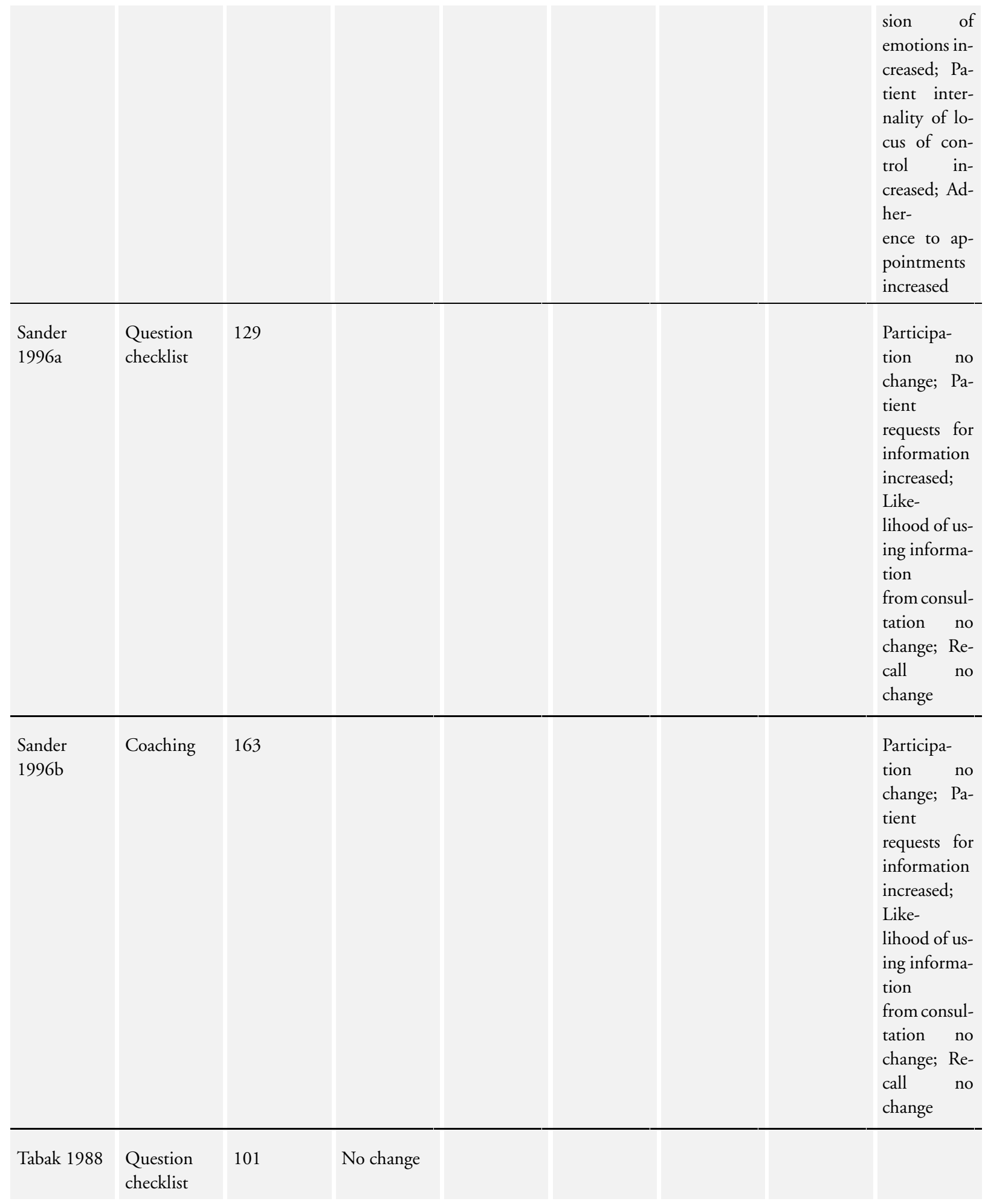


Table 2. Main outcomes for each study (Continued)

\begin{tabular}{|c|c|c|c|c|c|c|c|}
\hline $\begin{array}{l}\text { Tennstedt } \\
2000\end{array}$ & Coaching & 355 & & & $\begin{array}{l}\text { No change } \\
\text { except Inter- } \\
\text { personal sat- } \\
\text { isfaction in- } \\
\text { creased }\end{array}$ & & $\begin{array}{l}\text { Participa- } \\
\text { tion no } \\
\text { change }\end{array}$ \\
\hline $\begin{array}{l}\text { Thompson } \\
\text { 1990a }\end{array}$ & $\begin{array}{l}\text { Question } \\
\text { checklist }\end{array}$ & 66 & Increased & Reduced & No change & No change & $\begin{array}{l}\text { Clinician } \\
\text { satisfaction } \\
\text { no change }\end{array}$ \\
\hline $\begin{array}{l}\text { Thompson } \\
1990 \mathrm{~b}\end{array}$ & $\begin{array}{l}\text { Checklist of } \\
\text { in- } \\
\text { formation to } \\
\text { obtain; mes- } \\
\text { sage encour- } \\
\text { aging ques- } \\
\text { tions }\end{array}$ & 105 & No change & No change & Increased & & $\begin{array}{l}\text { Extent to } \\
\text { which ques- } \\
\text { tions } \\
\text { answered in- } \\
\text { creased; } \\
\text { Sense of } \\
\text { control in- } \\
\text { creased; Re- } \\
\text { call no } \\
\text { change }\end{array}$ \\
\hline $\begin{array}{l}\text { Wilkinson } \\
2002\end{array}$ & $\begin{array}{l}\text { Question } \\
\text { checklist }\end{array}$ & 278 & & & & & $\begin{array}{l}\text { Evalu- } \\
\text { ation of visit } \\
\text { no change; } \\
\text { health } \\
\text { record } \\
\text { review no } \\
\text { change apart } \\
\text { from } \\
\text { prostate } \\
\text { screening } \\
\text { (increased) }\end{array}$ \\
\hline
\end{tabular}

Table 3. Summary of outcomes sought

Outcomes sought

No. of studies

1) CONSULTATION PROCESS

Patients' perceptions of communication, including usefulness of 7 information provision

\begin{tabular}{l|l}
\hline Information seeking and participation & 14 \\
\hline Question asking & 17 \\
\hline Provision of information & 2 \\
\hline $\begin{array}{l}\text { Interventions before consultations for helping patients address their information needs (Review) } \\
\text { Copyright } \odot 2009 \text { The Cochrane Collaboration. Published by John Wiley \& Sons, Ltd. }\end{array}$
\end{tabular}


Table 3. Summary of outcomes sought (Continued)

\begin{tabular}{l|l}
\hline Verifying information & 0 \\
\hline Types of questions asked & 4 \\
\hline 2) CONSULTATION OUTCOMES & \\
\hline 2a) Patient health outcomes & 3 \\
\hline Symptom control & 5 \\
\hline Performance status (ability to undertake activities of daily living) & 2 \\
\hline Pysiological measures of disease control & 4 \\
\hline Physical health & 21 (including 12 studies measuring anxiety) \\
\hline Psychological health & 2 \\
\hline
\end{tabular}

2b) Patient care outcomes

i) Patient knowledge

Understanding/Knowledge acquisition

\begin{tabular}{l|l}
\hline Retention of information, recall of information & 6 \\
\hline Satisfaction with knowledge provision & 0 \\
\hline
\end{tabular}

ii) Evaluation of care

\begin{tabular}{l|l}
\hline Perception of care & 1 \\
\hline Patient satisfaction & 23 \\
\hline Perception of intervention & 3 \\
\hline iii) Self-efficacy & 2 \\
\hline Empowerment & 1 \\
\hline Enablement & 0 \\
\hline Confidence & 0 \\
\hline Ability to cope & 5 \\
\hline Sense of control &
\end{tabular}


Table 3. Summary of outcomes sought (Continued)

iv) Health behaviour

\begin{tabular}{l|l}
\hline Adherence (compliance) & 5 \\
\hline Lifestyle or behavioural outcomes & 0 \\
\hline Use of health services & 0 \\
\hline Use of intervention & 1 \\
\hline v) Treatment outcomes & 0 \\
\hline Adverse outcomes & 0 \\
\hline 3) SERVICE OUTCOMES & 3 \\
\hline Provision of information & 0 \\
\hline Clinician satisfaction & 17 \\
\hline Clinician perception of intervention & 4 \\
\hline Consultation length & 0 \\
\hline Service utilisation & \\
\hline
\end{tabular}

Table 4. Comparison of results with and without clustered data

\begin{tabular}{|c|c|c|c|c|}
\hline Comparison & Effect size all data & $95 \% \mathrm{CI}$ & Effect size no clust & $95 \% \mathrm{CI}$ \\
\hline \multicolumn{5}{|l|}{$\begin{array}{l}\text { INTERVENTION } \\
\text { VERSUS CONTROL }\end{array}$} \\
\hline $\begin{array}{l}\text { Anxiety (after consulta- } \\
\text { tion) }\end{array}$ & -0.08 & -0.22 to 0.06 & -0.09 & -0.23 to 0.06 \\
\hline Patient satisfaction & 0.09 & 0.03 to 0.16 & 0.09 & 0.02 to 0.16 \\
\hline Consultation length & 0.10 & -0.05 to 0.25 & 0.05 & -0.08 to 0.18 \\
\hline \multicolumn{5}{|l|}{$\begin{array}{l}\text { WRITTEN } \\
\text { MATERIALS VERSUS } \\
\text { COACHING }\end{array}$} \\
\hline Coaching: Satisfaction & 0.23 & 0.08 to 0.38 & 0.18 & -0.03 to 0.39 \\
\hline
\end{tabular}


Table 4. Comparison of results with and without clustered data (Continued)

\begin{tabular}{|c|c|c|c|c|}
\hline $\begin{array}{l}\text { Written materials: Con- } \\
\text { sultation length }\end{array}$ & 0.13 & 0.05 to 0.21 & 0.10 & 0.02 to 0.18 \\
\hline \multicolumn{5}{|l|}{$\begin{array}{l}\text { TIMING OF INTER- } \\
\text { VENTION }\end{array}$} \\
\hline $\begin{array}{l}\text { Immediately before con- } \\
\text { sultation: Satisfaction }\end{array}$ & 0.10 & 0.02 to 0.17 & 0.09 & 0.02 to 0.17 \\
\hline $\begin{array}{l}\text { Immediately before con- } \\
\text { sultation: Consultation } \\
\text { length }\end{array}$ & 0.16 & 0.03 to 0.29 & 0.12 & 0.01 to 0.22 \\
\hline \multicolumn{5}{|l|}{$\begin{array}{l}\text { CLINICIAN TRAIN- } \\
\text { ING }\end{array}$} \\
\hline $\begin{array}{l}\text { Clinicians trained: Satis- } \\
\text { faction }\end{array}$ & -0.01 & -0.15 to 0.12 & 0.02 & -0.14 to 0.17 \\
\hline $\begin{array}{l}\text { Clinicians not trained: } \\
\text { Satisfaction }\end{array}$ & 0.13 & 0.05 to 0.21 & 0.11 & 0.03 to 0.20 \\
\hline $\begin{array}{l}\text { Clinicians not trained: } \\
\text { Consultation length }\end{array}$ & 0.17 & 0.10 to 0.24 & 0.15 & 0.07 to 0.22 \\
\hline
\end{tabular}

\section{A P P E N D I CES}

\section{Appendix I. MEDLINE (Ovid) search strategy}

1 pamphlets/ or pamphlet\$.tw.

2 (leaflet\$ or diary or diaries or booklet\$ or guidebook\$).tw.

3 sheet $\$$.tw.

4 cues/ or cue $\$ . t w$.

5 (prompt $\$$ or coach $\$$ ).tw.

6 (checklist\$ or check list\$).tw.

7 agenda\$.tw.

8 (written or write).tw.

9 (question or questions or question?ing or question?ed).tw.

10 (information adj3 need $\$ 1$ ).tw.

11 (card or cards or helpcard\$).tw.

12 (video $\$$ or tape $\$$ or $\mathrm{cd} \$$ or film $\$$ or telephone $\$$ or phone $\$ 1$ or computer $\$$ ).tw. 
13 or/ $1-12$

14 communication/ or communicat\$.tw.

15 patient education/

16 ((patient\$ or consumer\$) adj3 (educat\$ or skill\$ or teach\$ or train\$ or coach\$)).tw.

1714 and (15 or 16$)$

1813 or 17

19 (preconsultation\$ or pre-consultation\$).tw.

20 office visits/ or (office adj3 visit\$).tw.

21 consult\$.tw.

22 (medical adj3 interview\$).tw.

23 waiting room $\$$.tw.

24 scheduled appointment\$.tw.

25 ((prior adj3 visit\$) or previsit\$).tw.

26 "appointments and schedules"/

27 or/ $19-26$

2818 and 27

29 randomized controlled trial.pt.

30 controlled clinical trial.pt.

31 randomized controlled trials.sh.

32 random allocation.sh.

33 double blind method.sh.

34 single blind method.sh.

35 or/29-34

36 animal/ not (human/ and animal/)

3735 not 36

38 clinical trial.pt.

39 exp clinical trials/

40 (clin\$ adj25 trial\$).ti,ab.

41 ( (singl\$ or doubl\$ or trebl\$ or tripl\$) adj25 (blind\$ or mask\$)).ti,ab.

42 placebos.sh.

43 placebo\$.ti,ab.

44 random $\$$.ti,ab.

45 research design.sh.

46 or $/ 38-45$

4746 not 36

4837 or 47

4928 and 48

50 (time adj series).tw.

51 (pre test or pretest or (post test or posttest)).tw.

52 cohort studies/ or cohort.tw.

5350 or 51 or 52

5428 and 53

5549 or 54 
WHAT'S NEW

Last assessed as up-to-date: 28 September 2006.

\begin{tabular}{lll}
\hline Date & Event & Description \\
\hline 8 May 2008 & Amended & Converted to new review format. \\
\hline
\end{tabular}

\section{H I S T O R Y}

Protocol first published: Issue 1, 2004

Review first published: Issue 3, 2007

\section{CONTRIBUTIONSOFAUTHORS}

Paul Kinnersley led this review identifying the initial need, writing the protocol, conducting the review process and writing the review. Hayley Prout, Diane Owen, Rebecca Ryan and Naomi Cadbury acted as independent reviewers of citations and conducted data extraction. They also assisted with the production of the review. Kerry Hood was the statistician for the review and directed the metaanalyses and statistical analyses. Adrian Edwards guided the review process and assisted with the production of the review and the interpretation of the results. Fergus MacBeth, Phyllis Butow and Chris Butler assisted with the production of the protocol and final review and the interpretation of the results.

\section{DECLARATIONS OF INTEREST}

Paul Kinnersley leads a Communication Skills Training Unit that generates income by delivering training to clinicians. Phyllis Butow is an author of two studies included in this review.

\section{SOURCES OFSUPPORT}

\section{Internal sources}

- Cardiff University, UK.

\section{External sources}

- No sources of support supplied 


\section{N D EX TERMS}

\section{Medical Subject Headings (MeSH)}

Anxiety [diagnosis]; Information Dissemination [* methods]; Patient Education as Topic [* methods]; Patient Participation; Randomized Controlled Trials as Topic

\section{MeSH check words}

Humans 